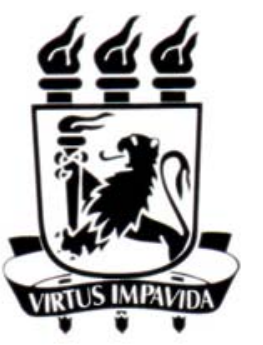
UNIVERSIDADE FEDERAL DE PERNAMBUCO-UFPE CENTRO DE TECNOLOGIA E GEOCIÊNCIAS-CTG DEPARTAMENTO DE OCEANOGRAFIA-DOCEAN PROGRAMA DE PÓS-GRADUAÇÃO EM OCEANOGRAFIA

\title{
Simulating gas blowout in tropical shallow waters
}

FABIANA SOARES LEITE

Recife/Brasil

2012 


\title{
Simulating gas blowout in tropical shallow waters
}

\author{
por
}

\section{FABIANA SOARES LEITE}

Tese apresentada ao Programa de Pós-graduação em Oceanografia da Universidade Federal de Pernambuco como requisito parcial para obtenção do título de Doutor em Ciências, na área de Oceanografia Física.

Orientador: Dr. Moacyr Araújo

Recife/Brasil

2012 
L533s Leite, Fabiana Soares.

Simulating gas blowout in tropical shallow waters / Fabiana Soares Leite. - Recife: O Autor, 2012.

$\mathrm{xv}, 115$ folhas, il., gráfs., tabs.

Orientador: $\operatorname{Prof}^{\circ}$ Dr. Moacyr Araújo.

Tese (Doutorado) - Universidade Federal de Pernambuco. CTG. Programa de Pós-Graduação em Oceanografia, 2012.

Inclui Referências.

1. Oceanografia. 2. Vazamento de Gás. 3. Águas Rasas. 4. Pluma de Gás. 5. Costa Tropical - Nordeste Brasil. I. Araújo, Moacyr (Orientador). II. Título. 


\title{
Simulating gas blowout in tropical shallow waters
}

\author{
por
}

\section{FABIANA SOARES LEITE}

Tese apresentada em 26/09/2012 e aprovada em estilo e conteúdo pela seguinte banca examinadora:

Titulares -

Dr. Moacyr Cunha de Araújo Filho (Orientador/UFPE)

Dra. Carmen Medeiros Limongi (DOCEAN/UFPE)

Dr. Carlos Esteban Delgado Noriega (CEERMA/UFPE)

Dr. Carlos Alessandre Domingos Lentini (DFT/UFBA)

Ph.D. Nadège Bouchonneau da Silva (DEMEC/UFPE)

Suplentes -

Dr. Héctor Raul Montagne Dugros (DF/UFRPE)

Dr. Márcio das Chagas Moura (DEP/UFPE) 
Aos meus amados pais,

Luiz Carlos Leite (In Memoriam)

e

Eliane $\mathbf{M}^{\mathrm{a}}$. Soares Leite. 


\section{Agradecimentos}

Ao professor e amigo Dr. Moacyr Cunha de Araújo Filho por sua orientação, confiança e incentivo desde minha entrada no Departamento de Oceanografia. O considero um profissional exemplar e tenho grande orgulho em tê-lo como orientador nesta jornada.

Ao amigo, e hoje professor, Marcus André Silva por sua coorientação extra-oficial, por compartilhar seus conhecimentos na área, pelas conversas no âmbito profissional e pelos momentos de descontração vivenciados ao longo destes anos.

Meus sinceros agradecimentos pela participação e contribuição dos membros da banca do exame de qualificação e da banca examinadora da defesa.

À Fundação de Amparo à Ciência e Tecnologia do Estado de Pernambuco (FACEPE) pela concessão da Bolsa de Doutorado.

Ao apoio do CNPq que tornou possivel a aquisição dos dados experimentais utilizados na tese através do projeto "Transporte e dispersão de uma pluma de gás natural no oceano: caracterização experimental, modelagem matemática e avaliação de impactos" (CNPq 550197/2005-2).

Aos amigos do LOFEC/CEERMA, especialmente Rodolfo, Dóris, Carlos Noriega e Patrícia Façanha, pelo companheirismo e amizade ao longo desses anos, bem como a todos os que participaram ativamente das campanhas de campo.

A todos os amigos da pós-graduação do DOCEAN, em especial a Xiomara pela amizade e momentos de descontração vivenciados.

Aos professores do DOCEAN, os quais muito me ensinaram sobre suas respectivas áreas e compartilharam de suas experiências.

Aos funcionários e demais colegas do DOCEAN e do CEERMA pela boa convivência e atenção a mim prestadas.

Aos meus pais, Lula (In Memoriam) e Eliane, irmãs, Mariana e Tatiana, Maria Nim, Melcei e a toda minha família pelo amor e apoio incondicionais recebidos ao longo de todos esses anos.

Enfim, minha eterna gratidão a todos aqueles que, de uma forma ou de outra, contribuíram para a realização desta tese. OBRIGADA! 


\section{Resumo}

A exploração de óleo e gás vem apresentando um rápido crescimento em regiões de baixa latitude, mesmo assim pouquíssimos experimentos e modelagens envolvendo vazamento de gás têm sido publicados pela comunidade científica. Este estudo foi desenvolvido de modo a aumentar o conhecimento a respeito do comportamento da pluma de gás durante um vazamento acidental em águas rasas. Os métodos usados e os resultados obtidos são apresentados neste estudo, assim como um modelo para simular o transporte e a dispersão de uma pluma de gás liberada em águas rasas. Primeiramente, experimentos de campo foram realizados através da simulação de um vazamento de gás natural a aproximadamente $30 \mathrm{~m}$ de profundidade na costa nordeste do Brasil. Quatro cenários distintos, com variadas condições de forçantes geofísicas, foram associados a diferentes fluxos de gás (de 3000 a 9000 L.h ${ }^{-1}$ ) e períodos sazonais (verão e inverno). Num segundo estágio, a análise de dispersão da pluma de gás foi realizada com os dados obtidos in situ. $\mathrm{O}$ modelo usou um volume de controle lagrangiano para discretização e simulou a evolução da pluma de gás associando a termodinâmica e o impacto desta na hidrodinâmica da pluma de gás. De acordo com os dados coletados, o transporte predominante da corrente ocorreu para sulsudoeste (nordeste) durante o verão (inverno). A diferença no diâmetro da pluma ocorreu principalmente na camada mais próxima à superfície. A pluma de gás deslocou-se para sul-sudoeste no verão e para nordestenorte durante o inverno. Os fluxos de gás liberados no assoalho oceânico pareceram não afetar a hidrodinâmica local. O movimento da pluma foi sempre influenciado pelas forçantes de maré e meteorológica, nesta ordem. Os resultados de modelagem indicaram que, à medida que a pluma sobe na coluna de água, a mesma é deslocada horizontalmente na direção da corrente predominante. A situação extrema estabeleceu um raio crítico (máximo deslocamento horizontal) da fonte de gás de $35,2 \mathrm{~m}$. A comparação entre os dados medidos e os calculados mostrou que o modelo representou satisfatoriamente as principais características da liberação de gás, tais como o deslocamento, o diâmetro e o tempo de ascensão da pluma. Apesar das plumas apresentarem a largura média da mesma ordem de magnitude entre as medições e os cálculos, melhorias podem aumentar o desempenho do modelo durante o desenvolvimento inicial das plumas. Dados importantes e únicos foram coletados durante os vazamentos de gás, os quais contribuíram para a caracterização do comportamento de diferentes fluxos em diferentes períodos. Os experimentos forneceram uma base de dados para um modelo computacional que foi capaz de reproduzir o transporte e a dispersão de uma pluma de gás no ambiente marinho. O modelo foi capaz de prever o transporte e destino do gás liberado no ambiente. O mesmo pode, portanto, ser usado como uma ferramenta para planos de contingência de vazamentos acidentais de gás no oceano. 
Palavras-chave: Vazamentos de gás; Dados experimentais; Modelagem de gás; Águas rasas; Costa nordeste do Brasil; Sudoeste do Atlântico Tropical. 


\begin{abstract}
$\underline{\text { Abstract }}$
Underwater oil and gas exploration has been growing fast in low latitude regions, even though very few experimental data acquisition and modeling involving gas release in tropical and shallow waters have been published by the scientific community. This study was developed to increase the knowledge concerning the gas behavior during a subsurface blowout in shallow waters. The methods used and the results obtained from this study are presented, as well as a model to simulate the transport and dispersion of a subsurface gas plume released from shallow waters. At first, field experiments were carried out by simulating a subsurface blowout with natural gas at approximately $30 \mathrm{~m}$ depth in the Northeast Brazilian coast. Four distinct scenarios with varied conditions of geophysical forcing were associated with different fluxes (from 3000 to 9000 L.h ${ }^{-1}$ ) and seasonal periods (summer and winter). As a second stage, the analysis of the gas plume dispersion was accomplished with the data obtained from the above campaigns. The model used a Lagrangian control volume for discretization and simulated the gas plume evolution, associating thermodynamics and the impact of the thermodynamics on the hydrodynamics of the gas plume. The predominant transport occurred toward the south-southwest (northeast) during the summer (winter) period. The difference in the plume width occurred mainly in the upper surface layer. The gas plume displaced toward the south-southwest (northeast-north) during the summer (winter) period. The gas flow releases seemed not to affect the local hydrodynamics. The plume movement was always influenced by the tidal and meteorological forcings, in that order. The simulation results indicated that, as the gas plume rose in the water column, the same plume was horizontally displaced toward current predominant direction. The extreme situation provided a critical radius (maximum horizontal displacement) from the gas release source of $35.2 \mathrm{~m}$. The comparison between the measured and the calculated data showed that the model satisfactorily represented the main features of the gas release, such as the displacement, diameter and ascending time of the plume. Although the mean plume widths have the same order of magnitude between the measurements and the calculations, improvements may enhance the model's performance during the earlier plume development. Important and unique data were collected during these subsurface releases, which contributed to the characterization of the behavior of different blowouts in different seasons. The experiments provided a baseline for a computational model capable of reproducing gas plume transport and dispersion in the marine environment. The model was able to predict the gas release transport and fate in the environment. Thus it can be used as a tool for contingency planning of an accidental underwater gas release.
\end{abstract}


Keywords: Underwater gas blowouts; Experimental data; Gas modeling; Shallow water; Northeastern Brazilian coast; Southwestern Tropical Atlantic. 


\section{List of Figures}

\section{Chapter 1}

Figure 1. Worldwide field experiments at sea.

Figure 2. Example of the comparison of measured and modeled width of the plume using SINTEF blowout model (source: Rye et al., 1997)......... 22

Figure 3. Example of the comparison between the larger-scale data radius and the numerical model's results developed by Yapa and Zheng (1997) (source: Zheng and Yapa, 1998).

Figure 4. Comparison between the model simulation with gas and water, developed by Zheng et al. (2002), and the Echo Sounder data at 0-300 m (source: Chen and Yapa, 2002).

Figure 5. Comparison between the numerical data, developed by Yapa et al. (1999), and the observed data (source: Yapa and Xie, 2002). 24

\section{Chapter 2}

Figure 1. Map of the coastal region where sea experiments were carried out (source: Google Earth, 2010).... 28

Figure 2. Schematic figure of field campaigns. 30

Figure 3. Bubble plume definition sketch adopted in the modeling (source: Friedl and Fanneløp, 2000). 34

\section{Chapter 4}

\section{Figures from the paper}

Figure 1. Localization map in the coastal region of the Suape Harbor, Pernambuco, Brazil ( $\square$ ), presenting the experimental station ( $\mathbf{x})$, located $11 \mathrm{~km}$ far from the coastline (solid line). Isobaths of $20 \mathrm{~m}$ (dashed line) and $30 \mathrm{~m}$ (dash-dotted line) are also plotted. 
Figure 2. Logistic scheme of the field campaigns.

Figure 3. Set of used equipment for gas release from the sea bottom...... 77

Figure 4. Polar plots of the mean current velocity for the surface ( $\square$ ), middle $(\triangle)$ and bottom $(0)$ of the water column in the summer spring low tide during the low (a) and high (b) gas flow release; and in the neap ebb tide during the low (c) and high (d) gas flow release.

Figure 5. Examples of vertical CTD profiles obtained off Suape Harbor, Brazil, during: (a) austral summer; and (b) austral winter period.

Figure 6. Screenshots of the natural gas plume vertical evolution during the summer period campaigns. Neap ebb tide at the depths of (a) $4 \mathrm{~m}$ and (b) $24 \mathrm{~m}$ during high flow release. Spring low tide at the depths of (c) $1.5 \mathrm{~m}$ and (d) $19 \mathrm{~m}$ during low flow release and of (e) $4 \mathrm{~m}$ and (f) $20 \mathrm{~m}$ during high flow release. Spring flood tide at the depths of (g) $15 \mathrm{~m}$ and (h) $24 \mathrm{~m}$ during low flow release and of (i) $3 \mathrm{~m}$ and (j) $21 \mathrm{~m}$ during high flow release. 84

Figure 7. Gas plume evolution for $\mathrm{C} 1$ campaign (summer/ neap tide) during the ebb tide from (a) east to west and (b) north to south with a $6000 \mathrm{~L} / \mathrm{hr}$ flow and (c) east to west and (d) north to south with a 9000 $\mathrm{L} / \mathrm{hr}$ flow. The horizontal lines correspond to the observed plume diameter at the specific depth.

Figure 8. Gas plume evolution for $\mathrm{C} 2$ campaign (summer/ spring tide) during the low tide from (a) east to west and (b) north to south with a $3000 \mathrm{~L} / \mathrm{hr}$ flow and (c) east to west and (d) north to south with a 9000 $\mathrm{L} / \mathrm{hr}$ flow. During the flood tide, (e) east to west and (f) north to south with a $3000 \mathrm{~L} / \mathrm{hr}$ flow and (g) east to west and (h) north to south with a 9000 $\mathrm{L} / \mathrm{hr}$ flow. The horizontal lines correspond to the observed plume diameter at the specific depth. 86

Figure 9. Gas plume evolution for $\mathrm{C} 4$ campaign (winter/ neap tide) during the high tide from (a) east to west and (b) north to south with a $3000 \mathrm{~L} / \mathrm{hr}$ flow; and (c) east to west and (d) north to south with a $9000 \mathrm{~L} / \mathrm{hr}$ flow. 
During the ebb tide, (e) east to west and (f) north to south with a 3000 $\mathrm{L} / \mathrm{hr}$ flow and (g) east to west and (h) north to south with a $9000 \mathrm{~L} / \mathrm{hr}$ flow. The horizontal lines correspond to the observed plume diameter at the specific depth. 88

Figure 10. Gas plume distances from the gas source at the moment that they reach the sea surface: (a) summer neap ebb tide (small/large circles for low/high flows); (b) summer spring tide (small/large circles for low/high flows during flood tide, inside a dashed rectangle, and small/large dashed circles for low/high flows during low tide); (c) winter spring low tide (high flow); (d) winter neap tide (small/large circles for low/high flows during ebb tide, inside a dashed rectangle, and small/large dashed circles for low/high flows during high tide). 89 


\section{List of Tables}

\section{Chapter 2}

Table 1. Campaigns carried out during the sea experiments................. 29

Table 2. Constant values used in model's simulations........................... 40

\section{Chapter 4}

\section{Tables from the paper}

Table 1. Summary of the sea campaigns........................................ 74

Table 2. Model input data/parameters used in simulations................... 79

Table 3. Synthesis observed (in situ) and modeled results gas plume features for different sea campaigns................................................. 93 


\section{List of Abbreviations}

\section{Equipment}

ADCP: Acoustic Doppler Current Profiler

CTD: Conductivity Temperature Depth

ROV: Remotely Operated Vehicle

\section{$\underline{\text { Models }}$}

CDOG: Comprehensive Deepwater Oil and Gas Blowout Model

COMBOS3D: Three-Dimensional Comprehensive Oil Spill Model for Surface and Underwater spills

MEGADEEP: MEthane GAs in DEEPwater model

\section{Others}

DOCEAN: Departamento de Oceanografia da Universidade Federal de Pernambuco

LOFEC: Laboratório de Oceanografia Física, Estuarina e Costeira do Departamento de Oceanografia da Universidade Federal de Pernambuco

PPGO/DOCEAN: Programa de Pós-Graduação em Oceanografia do Departamento de Oceanografia

SINTEF: Selskapet for INdustriell og TEknisk Forskning ved norges tekniske hoegskole (The Foundation for Scientific and Industrial Research at the Norwegian Institute of Technology)

TKE: Turbulent Kinetic Energy

UFPE: Universidade Federal de Pernambuco 


\section{List of Nomenclature}

\footnotetext{
$\mid \mathrm{V}$ local plume velocity $\left[\mathrm{m} \cdot \mathrm{s}^{-1}\right]$

$\left|V_{0}\right| \quad$ initial blowout velocity $\left[\mathrm{m} \cdot \mathrm{s}^{-1}\right]$

A surface area of a gas bubble $\left[\mathrm{m}^{2}\right]$

$C_{0}$ dissolved gas concentration [mol. $\left.\mathrm{m}^{-3}\right]$

$\mathrm{C}_{\mathrm{s}} \quad$ gas solubility $\left[\mathrm{mol} . \mathrm{m}^{-3}\right]$

$\mathrm{J}$ gas bubble flow inside the control volume [bubble $\mathrm{n}^{\mathrm{o}} . \mathrm{s}^{-1}$ ]

$\mathrm{K} \quad$ coefficient of mass transfer $\left[\mathrm{m} . \mathrm{s}^{-1}\right]$

$\mathrm{M}_{0} \quad$ excess momentum in the control volume $\left[\mathrm{m}^{4} \cdot \mathrm{s}^{-2}\right]$

$\mathrm{M}_{\mathrm{g}} \quad$ gas molecular weight $\left[\mathrm{kg} \cdot \mathrm{mol}^{-1}\right]$

$\mathrm{M}_{\mathrm{w}} \quad$ water molecular weight $\left[\mathrm{kg} \cdot \mathrm{mol}^{-1}\right]$

$\mathrm{P} \quad$ ambient pressure $[\mathrm{Pa}]$

$Q_{e} \quad$ entrainment water flux $\left[\mathrm{m}^{3} \cdot \mathrm{s}^{-1}\right]$

$\mathrm{Q}_{\mathrm{g}} \quad$ gas flux $\left[\mathrm{m}^{3} \cdot \mathrm{s}^{-1}\right]$

$Q_{s} \quad$ shear-induced entrainment water flux $\left[\mathrm{m}^{3} \cdot \mathrm{s}^{-1}\right]$

$\mathrm{Q}_{\mathrm{x}}, \mathrm{Q}_{\mathrm{y}}, \mathrm{Q}_{z}$ forced entrainment components in $\mathrm{x}, \mathrm{y}$ and $\mathrm{z}$, respectively $\left[\mathrm{m}^{3} \cdot \mathrm{s}^{-1}\right]$

$\mathrm{R} \quad$ universal gas constant [8.31 J.mol.K]

$\mathrm{T}$ temperature $[\mathrm{K}]$

$U_{0} \quad$ initial velocity of the gas and oil mixture $\left[\mathrm{m} . \mathrm{s}^{-1}\right]$

$U_{A} \quad$ velocity of the currents in the ocean $\left[\mathrm{m} \cdot \mathrm{s}^{-1}\right]$

$\mathrm{X}_{\text {SEP }} \quad$ plume separation $[\mathrm{m}]$

$\mathrm{X}_{\mathrm{sw}} \quad$ characteristic length scale $[\mathrm{m}]$

Z compressibility factor

b plume radius $[\mathrm{m}]$

$b_{0} \quad$ ratio of the initial control volume [m]

g gravity acceleration $\left[\mathrm{m}^{2} \cdot \mathrm{s}^{-1}\right]$
} 
h depth OR height of the control volume [m]

$m_{b}, m_{h}, m_{1}$ mass of the gas, hydrates and liquid, respectively, in the plume $[\mathrm{kg}]$

$\mathrm{n}$ number of moles of gas in a bubble [mol]

$\mathrm{n}_{\mathrm{h}} \quad$ hydrate number

$\mathrm{u}, \mathrm{v}$ plume horizontal velocities in the $\mathrm{x}$ and $\mathrm{y}$ directions, respectively $\left[\mathrm{m} \cdot \mathrm{s}^{-1}\right]$

ambient horizontal velocities in the $\mathrm{x}$ and $\mathrm{y}$ directions, respectively $\left[\mathrm{m} . \mathrm{s}^{-1}\right]$

w plume vertical velocity $\left[\mathrm{m} . \mathrm{s}^{-1}\right]$

$\mathrm{w}_{\mathrm{a}} \quad$ ambient vertical velocity $\left[\mathrm{m} \cdot \mathrm{s}^{-1}\right]$

$\mathrm{w}_{\mathrm{b}} \quad$ gas bubble (or bubble slip) velocity $\left[\mathrm{m} . \mathrm{s}^{-1}\right]$

$\Delta$ tor $\tau \quad$ specified time step [s]

$\Delta x, \Delta y, \Delta z$ displacements of a control volume in the $x, y, z$ directions, respectively $[\mathrm{m}]$

$\alpha \quad$ entrainment coefficient

$\beta \quad$ ratio between the cross-sectional areas occupied by the gas and that of the plume OR the gas core width/jet diameter

$\varepsilon$ or $\mathrm{f} \quad$ volume fraction of gas bubbles (including hydrate)

$\rho$ density of the gas plume and the liquid mixture $\left[\mathrm{kg} \cdot \mathrm{m}^{-3}\right]$

$\rho_{\text {a }}$ density of the ambient seawater $\left[\mathrm{kg} \cdot \mathrm{m}^{-3}\right]$

$\rho_{\text {com }} \quad$ composite density of the hydrates and gas $\left[\mathrm{kg} \cdot \mathrm{m}^{-3}\right]$

$\rho_{1} \quad$ liquid density of plume $\left[\mathrm{kg} \cdot \mathrm{m}^{-3}\right]$ 


\section{Table of Contents}

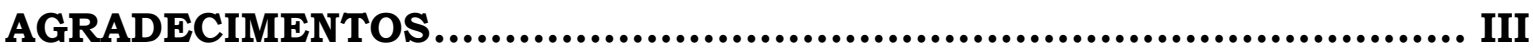

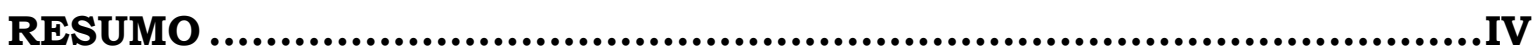

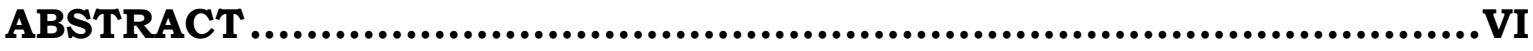

LIST OF FIGURES ..................................................................... VIII

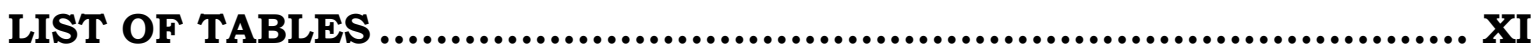

LIST OF ABBREVIATIONS ....................................................... XII

LIST OF NOMENCLATURE .......................................................... XIII

TABLE OF CONTENTS ..............................................................

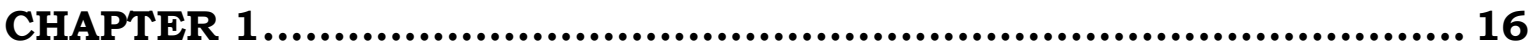

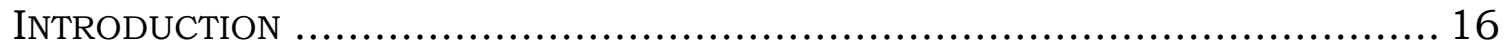

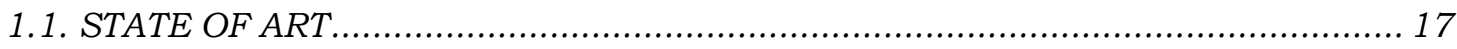

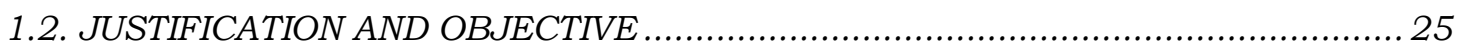

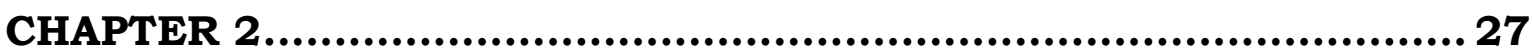

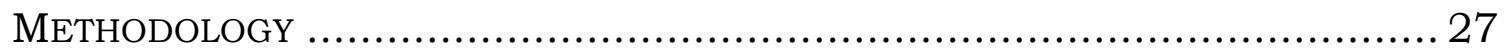

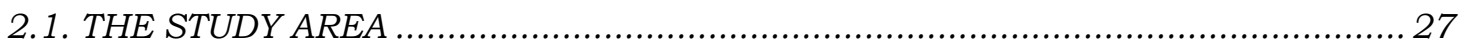

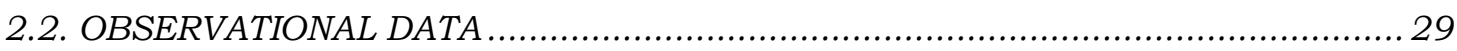

2.2.1. Field Experiment Planning and Preparations ........................................... 29

2.2.2. Gas Release Apparatus Arrangement ......................................................... 31

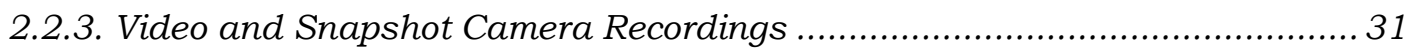

2.2.4. Sea Measurements ................................................................................... 32

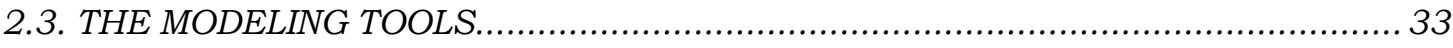

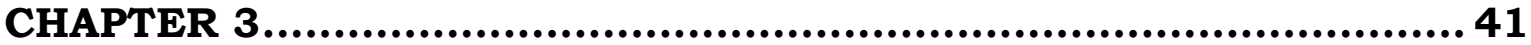

EXPERIMENTAL SET-Up AND Field DATA ACQUisition ......................... 41

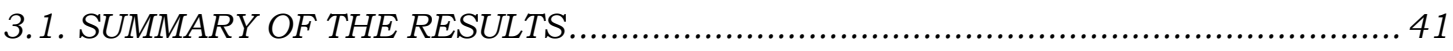

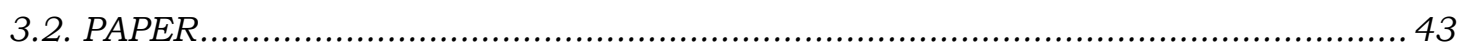

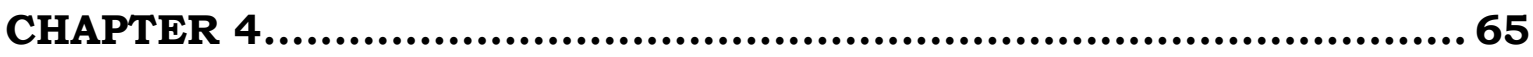

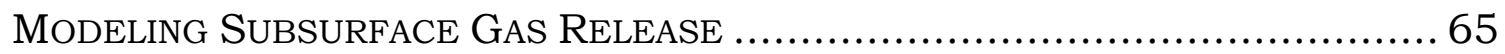

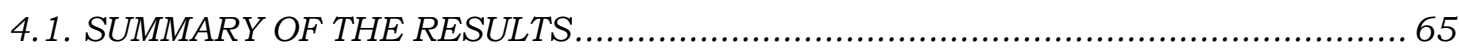

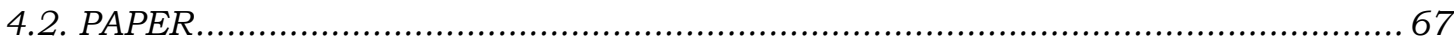

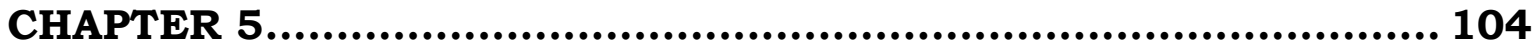

Conclusions ANd Perspectives ................................................ 104

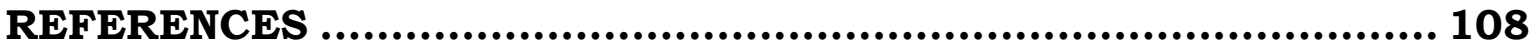




\section{Chapter 1}

\section{Introduction}

Oil and gas exploration and exploitation from the sea floor has been a growing and lucrative activity around the world. With this growth, the possibility of an accidental oil/gas release increases and consequently enhances the need for a better understanding of the dimensions and behavior of the plumes. It is important to know where, when and how much gas will reach the surface. This motivation requires realistic descriptions of blowout scenarios based on field experiments. Further, as part of a contingency planning, these experiments will provide a baseline for the calibration and validation of computational models developed to describe subsurface plume behavior (e.g., Rye et al., 1997; Yapa et al., 1999; Chen and Yapa, 2002; Johansen et al., 2003). Hence, more precise mathematical models are needed to better understand the behavior and dimensions of oil/gas plumes in addition to their consequences to the environment.

In situ experiments are expensive and demand logistical planning, even on a small scale, because they require manpower, equipment and vessels. Furthermore, these experiments are dangerous because methane gas clouds can generate explosions (Fischer, 1982; Beegle-Krause and Lynch, 2005). In certain regions, such as the North Sea, vessels are 
prohibited to work above a gas blowout due to the potential for explosion, based on previous shallow water blowout experience (Johansen et al., 2003). The major concern about accidental gas and oil blowouts is not only explosion/fire (Chen and Yapa, 2002). Other factors include the toxicity risks to humans and to the environment, and the commitment of ship buoyancy (or any floating object) due to the density decrease caused by the oil/gas mixture in the water. As a consequence very few in situ experiments have been reported in the literature, and most of them have been carried out in high latitude/deep water situations (Brewer et al., 1997; Rye et al., 1997; Johansen et al., 2003).

\subsection{STATE OF ART}

There are many differences between deep and shallow water blowouts as Zheng et al. (2002) described. The major differences are the gas hydrate formation and decomposition that occur in deep water blowouts due to the high pressure and low temperature and the gas dissolution for deep water levels. For blowouts at shallow to moderate depths, the gas dissolution from rising bubbles into seawater may be negligible because its residence time is short (Johansen, 2000). Gas expands as it rises because of the pressure decrease and thus increases the buoyancy of the jet/plume (Zheng et al., 2002). Due to the difficulties mentioned above, there have been few experiments at sea (Figure 1). The major findings from several gas injection field experiments are summarized below.

Brewer et al. $(1997,1998)$ investigated the process of methane hydrate formation in experiments conducted during January 1996 at the depth of $910 \mathrm{~m}$ in Monterey Bay, USA. The authors also aimed to develop instruments and methods for research in the natural sedimentary setting of the methane gas. For the experiments, the authors supplied a remotely operated vehicle (ROV) with a methane gas tank, two types of sediment 


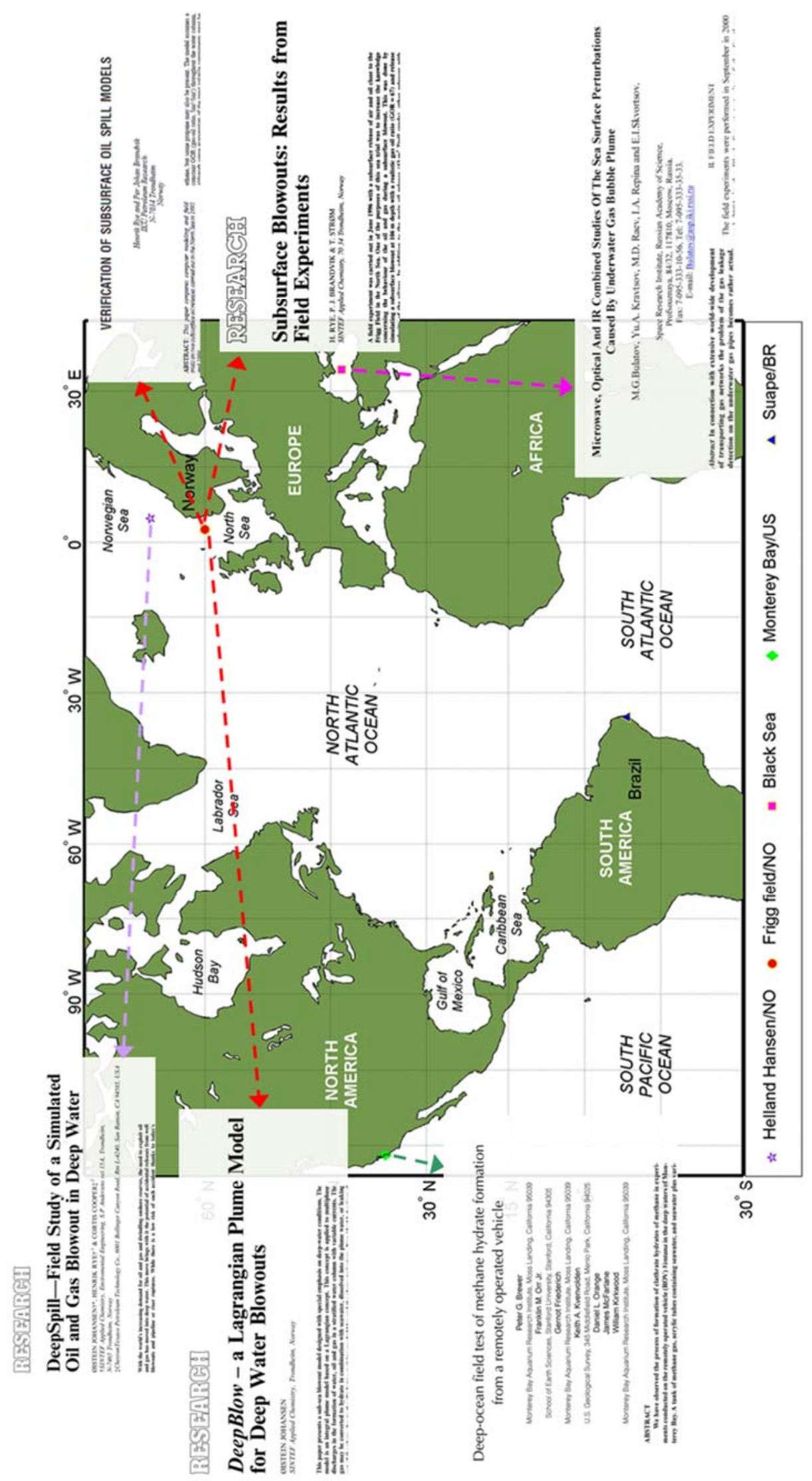

Figure 1. Worldwide field experiments at sea. 
and four samplers, while ambient seawater pressure and temperature were used. They concluded that the formation of hydrates was rapid in seawater and that the sediment type was important for the hydrate formation pattern. In addition, the use of ROV technology was fundamental for their research.

Rye et al. (1997) performed an in situ experiment with air and oil subsurface releases at $106 \mathrm{~m}$ during June 1996 in the North Sea. They collected data to improve their knowledge concerning oil/gas plume behavior during a blowout. They reproduced different blowout conditions and monitored the plume and the resulting surface oil slick. Moreover, they created a database for improving blowout models. Remote sensing of the surface slick was obtained, and they additionally used Metocean buoys, a CTD (conductivity, temperature, depth) and a ROV. The authors observed that the sampling methodology used was appropriate and that the model showed good representation of the release. Real and modeled plume presented the same proportions, although the size of the slick at the sea surface was overestimated by the model.

The experiment performed by Bulatov et al. (2002) was based on gas plume detection by microwave remote sensing methods without attention to the physical conditions of the plume. The experiment was executed during 2000/2001 using compressed air in the Black Sea. The authors observed that radar images of the perturbed zone presented great polarization dependence and concluded that microwave remote sensing is effective for detecting underwater gas pipe leakage.

The DeepSpill set of experiments were carried out by Johansen et al. $(2001,2003)$ in June 2000 at a depth of $844 \mathrm{~m}$ in the Norwegian Sea. The main goals of these experiments were to obtain high-quality data from a deep water oil/gas release and to use them to calibrate deep water plume models (Chen and Yapa, 2002). They also intended to explore methods to track the oil plume. For the trials, the authors used ROVs, echo sounders, an ADCP (Acoustic Doppler Current Profiler), a CTD and a rosette, in addition to boats, vessels and airplanes. The results indicated that the gas 
had dissolved entirely by $150 \mathrm{~m}$ beneath the surface, and no gas hydrates were formed. Furthermore, the oil reached the surface a few hundred meters from the blowout source an hour after the initial release.

Initial efforts to simulate the evolution of a single gas plume in the ocean were conducted by Fanneløp and Sjøen (1980). Those authors proposed a simplified analytical model for oil spills in shallow waters with nondimensional solutions. The classical ideal gas theory was considered to estimate the gas expansion throughout the water column. However, the authors neglected the horizontal advection of the gas by the ocean currents. Later, Friedl and Fanneløp (2000) improved the model by adding routines for the fountain effect, when the sea surface is elevated by the gas reaching the surface.

Different models have been proposed and improved to simultaneously characterize and predict the behavior of gas and oil blowouts in the ocean. Three well-known mathematical models are the SINTEF blowout model (Rye et al., 1997), the DeepBlow model (Johansen, 2000) and CDOG (Zheng et al., 2002). Modeling studies are also found in Yapa and Zheng (1997), Spaulding et al. (2000), Yapa et al. (2001), Chen and Yapa (2004) and Dasanayaka and Yapa (2009). However, studies specifically on gas release are more restricted and have been performed, for example, by Fanneløp and Sjøen (1980), Yapa and Xie (2002), Yapa et al. (2008a; 2008b).

Initially, the classical ideal gas theory was used to study plume evolution (Fanneløp and Sjøen, 1980), and the essential processes at great depths were not considered. For example, Yapa and Zheng (1997) considered only the advective transport of the gas and the environmental thermodynamic conditions in equations to predict the space-time evolution of plumes.

Eventually, improved gas modeling began to consider two important processes in deep water: gas dissolution (Zheng and Yapa, 2002; Johansen, 2003) and gas hydration (Topham, 1984a, b; Brewer et al., 1998; Chen and Yapa, 2001; Yapa et al., 2008b). According to Johansen 
(2003), the dissolution of gas into seawater is negligible for blowouts at shallow depths due to the short residence time of the gas bubbles. However, in deep water, the rising time of gas bubbles takes longer, possibilitizing dissolution (Johansen, 2000). In addition, under high pressure and low temperature, the gas can be converted into a solid-like phase called a gas hydrate (Johansen, 2003; Yapa et al., 2008b). Hydrate formation, which is a physically reversible process, might change the buoyancy of the plume in the water column (Chen and Yapa, 2001).

A comparison between field and model's results may therefore reveal where the largest potential for the improvement of existing models is expected. The main publications comparing experimental and numerical data are briefly described in the following sections.

Rye et al. (1997) used the SINTEF blowout model, which is a combination of two other subsurface release models published by Koh and Fan (1970) and Fanneløp and Sjøen (1980). Both models are based on the principle of the conservation of mass, momentum and buoyancy to simulate the mixing of a subsurface jet. However, neither model considers the ambient currents that can cause bending on subsurface plumes. The authors found that the field methodology was appropriate to simulate the mixing of a jet. A number of features obtained from the field measurements (formerly described) were well reproduced by the model, such as the subsurface plume dimensions and the rising time of the plume. However, other features were not properly represented, such as its diameter (Figure 2), which was smaller than the measured one, and the vertical velocity, which was higher than that observed, of the subsurface plume.

Yapa and Zheng (1997) developed a three-dimensional numerical model based on the Lagrangian method to simulate the behavior of an oil and gas plume during a blowout. It considered shear-induced and forced entrainments in addition to stratified and unstratified ocean environments and multi-directional ambient currents. Zheng and Yapa (1998) used experimental data comprising buoyant jets in unstratified and stratified 
environments. Those data included cases both with and without ambient currents, as well as bi- and tri-dimensional jet trajectories. The observed data were collected on small and large scales and compared with the numerical model's results (Figure 3) presenting satisfactorily comparable results.

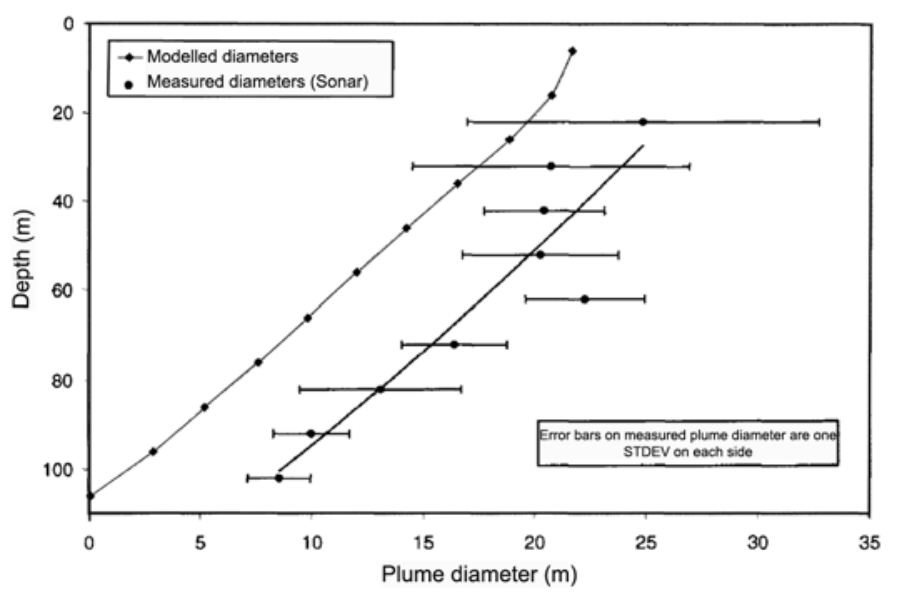

Figure 2. Example of the comparison of measured and modeled width of the plume using SINTEF blowout model (source: Rye et al., 1997).

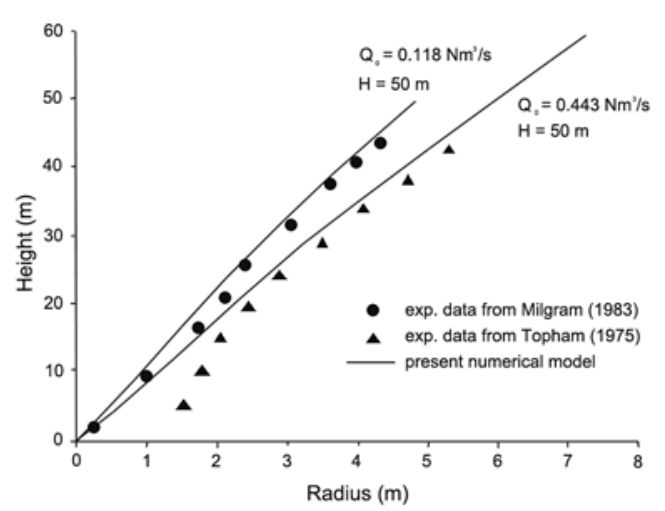

Figure 3. Example of the comparison between the larger-scale data radius and the numerical model's results developed by Yapa and Zheng (1997) (source: Zheng and Yapa, 1998).

Zheng et al. (2002) developed a mathematical model called CDOG (Comprehensive Deepwater Oil and Gas Blowout Model) to simulate the behavior of oil and gas plumes released into deep waters. The model integrates a set of modules regarding jet/plume hydrodynamics and thermodynamics, the kinetics and thermodynamics of hydrate formation, 
decomposition and gas dissolution. The numerical results obtained by CDOG were compared with the "DeepSpill" field data (Johansen et al., 2001, 2003) by Chen and Yapa (2002) and presented satisfactory results (Figure 4), despite some constrains related to the experiments like the uncertainty regarding hydrate formation. In addition, the authors concluded that gas releases from those depths (approximately $800 \mathrm{~m}$ ) would be entirely dissolved before they could reach the surface.

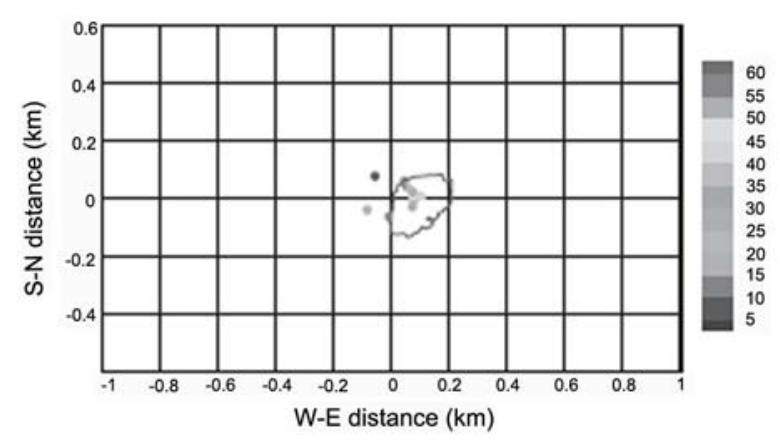

Figure 4. Comparison between the model simulation with gas and water, developed by Zheng et al. (2002), and the Echo Sounder data at 0-300 m (source: Chen and Yapa, 2002).

The experiments performed by Rye et al. (1997) were simulated by Yapa and Xie (2002) using the COMBOS3D model (Yapa et al., 1999) with the purpose of testing the model's ability to predict underwater blowouts (Figure 5). The same set of coefficients was used for all the simulations and the entrainment formula was described by Yapa et al. (1999). The comparison between numerical and experimental data was reasonably good for distances far from the nozzle, and better results were obtained for jets with a higher GLR (gas to liquid ratio), which was from $67 \mathrm{~N} \cdot \mathrm{m}^{3} \cdot \mathrm{s}^{-1}$ / $\mathrm{m}^{3} \cdot \mathrm{s}^{-1}$ and greater. The differences observed were due to experimental errors and the inadequate entrainment provided by the entrainment formula for the lower GLR. The authors concluded that the model was capable of simulating oil and gas spills only if no hydrates were formed. 


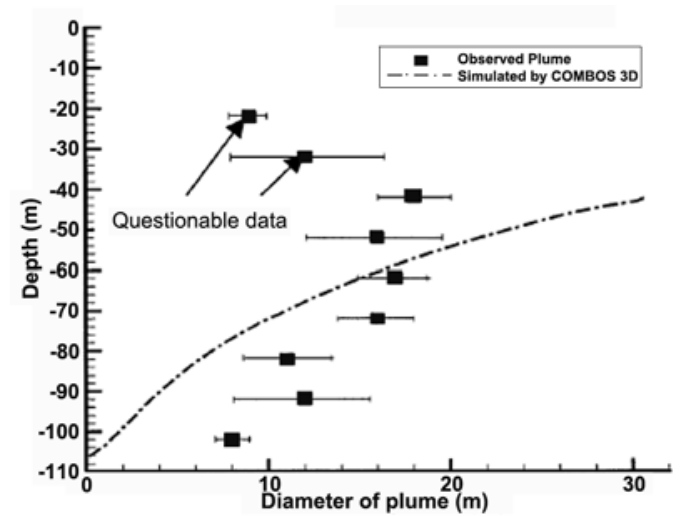

Figure 5. Comparison between the numerical data, developed by Yapa et al. (1999), and the observed data (source: Yapa and Xie, 2002).

A coherent dataset collected in deep water that allowed calibration of plume models was generated by the DeepSpill experiments presented by Johansen et al. (2003). Comparing its experimental data with the numerical results of the DeepBlow model (Johansen, 2000) was part of their analysis. The model included cross currents, gas dissolution, hydrate formation, gas bubbles escape from a bent plume and underwater plume trapping. The numerical results predicted hydrate formation, but no hydrate was observed. Modeled natural gas dissolved faster than the field data. After some adjustments, the model satisfactorily predicted the surfacing time of the plume and the location of the slick. In another publication, Johansen (2003) reviewed the theories and behaviors of deep water blowouts and compared them to those for shallow water. The author observed that the slick formation in deep water releases would be governed by the surfacing of individual oil droplets in a depth and time variable current. In contrast, for shallow and moderate deep waters, the bubble plume would rise to the surface, forming a strong radial flow and, consequently, contributing to a rapid spreading of the oil in the surface.

Yapa et al. (2008a) developed the MEGADEEP (MEthane GAs in DEEPwater) model to simulate the transport of methane gases from deep water. The foci of this model were gas and hydrates, and the model included gas hydrate formation and dissociation, gas and hydrate dissolution, hydrate crumbling and reformation, and gas bubble size 
variety and splitting. As part of their analysis, the authors simulated the DeepSpill experiments and compared the numerical results with the DeepSpill field data. The simulations worked well, except for the simulation that formed hydrates, once it was not observed during the experiments. This discrepancy was attributed to experimental uncertainties.

\subsection{JUSTIFICATION AND OBJECTIVE}

To our knowledge, there are very few studies addressing the analysis of gas plume evolution in coastal and tropical shallow waters. Neither the acquisition of experimental data nor its comparison to model's results was found in the literature. Collecting a comprehensive data set from shallow water gas releases in the Northeast of Brazil provides a valuable one-time view of the fate of such gases. The data obtained from a prosperous gas/oil-producing region of the world would enhance the knowledge concerning blowouts in shallow tropical waters. These data would additionally supply a baseline for model validation and fine-tuning. This study also describes a model developed to simulate the transport and dispersion of a subsurface gas plume released into shallow waters. It presents the model formulations and its use to simulate and compare the results with the small-scale field experiments conducted along the Northeast Brazilian coast.

The main objective of this study is to analyze the evolution of natural gas plumes under the hydrodynamics of a tropical and shallow coastal region regarding an accidental gas blowout. To achieve this intent, specific goals were performed:

- Execution of field experiments to characterize the evolution of hydrocarbon plumes in the water column during distinct seasonal and dynamic situations; 
- Execution of field experiments to determine the occurrence of hydrodynamic forcing during dry and rainy seasons for neap and spring tides during in situ experiments;

- Development of a numerical model to simulate the transport and dispersion of a subsurface gas plume released from shallow waters;

- Verification of the model output through comparison between numerical and experimental data.

This manuscript is structured as follows. Chapter 2 describes the Methodology used including an overview of the study area, a detailed description of the field experiments and the main model formulations. In Chapters 3 and 4, the main contributions from this study are described. In each of these two chapters, a synthesis of the results is initially presented followed by a copy of the manuscript submitted to two scientific journals. Finally the main conclusions and perspectives are given in Chapter 5. 


\section{Chapter 2}

\section{Methodology}

\subsection{THE STUDY AREA}

The sea experiments were conducted in the coastal region near the Suape Harbor industrial park area, Pernambuco, Brazil (Figure 1). According to the Köppen-Geiger climate classification scheme (Peel et al., 2007), the climate is warm and humid (type Am) in the region. Two welldefined seasons are observed, which are the dry season (from September to March) and the raining season (from April to August). The average annual rainfall is $1,500 \mathrm{~mm}$, and the evaporation is $1,200 \mathrm{~mm}$. According to Araujo et al. (2005), semidiurnal tides occur at Suape with a mean spring range of $2.2 \mathrm{~m}$, and mean neap range of $1.1 \mathrm{~m}$. The southeasterly trade winds are predominant throughout the year, oscillating from the east and the northeast during summer (Lins, 2002).

A weak daily thermocline (halocline) occurs near the surface as a result of radiation (evaporation) during the day. Below this region, a wellmixed and homogeneous flow has been observed. The current intensity indicates the influence of momentum exchange near the surface and bottom boundary layers (Araujo et al., 2005). According to the upper flow 


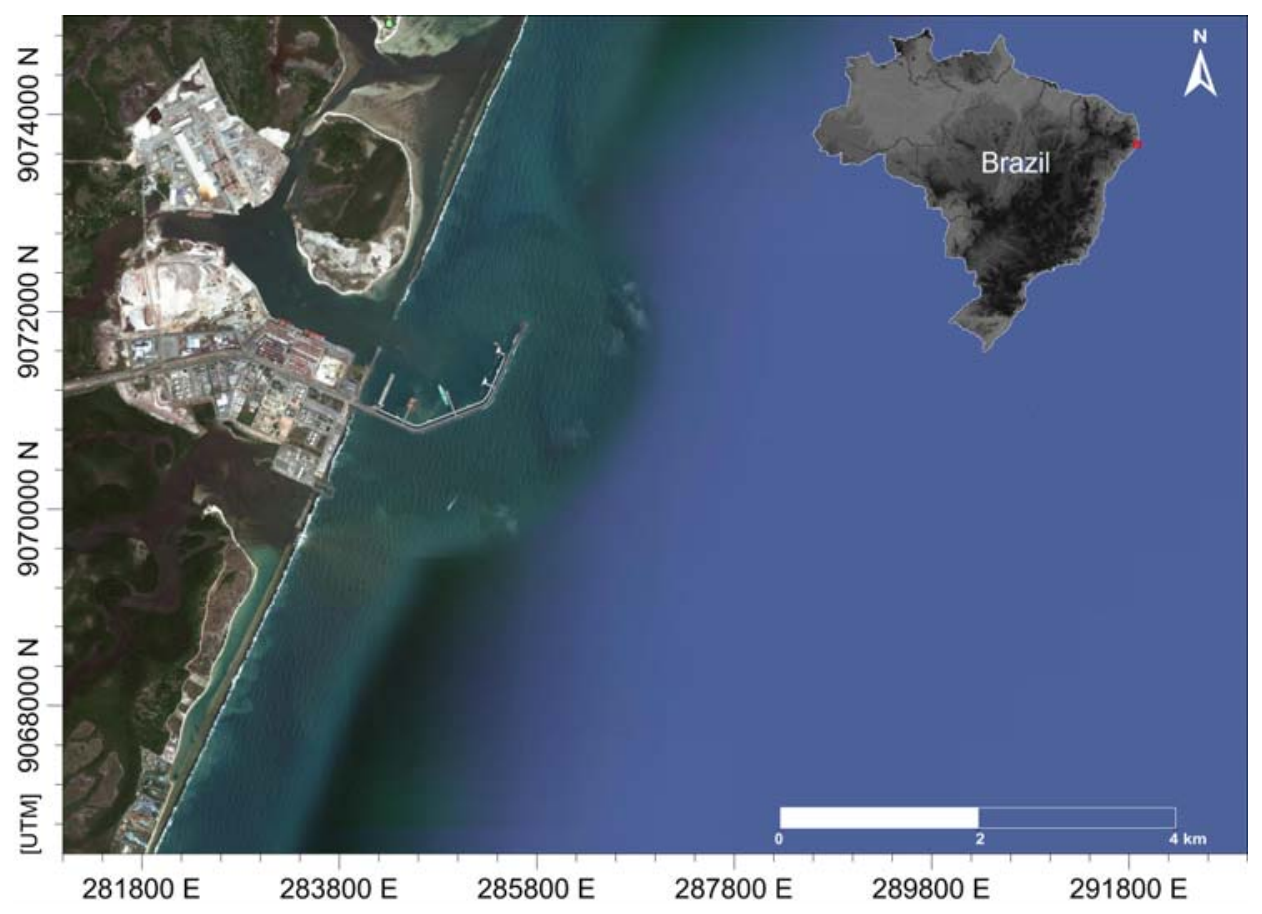

Figure 1. Map of the coastal region where sea experiments were carried out (source: Google Earth, 2010).

structures, the authors observed stronger surface variations in the current intensity and direction, which were associated with slack waters, when the wind effects were more pronounced. The authors also noticed weak wind shear effects near the surface that were associated with the strong bottom variations in current direction during the dynamic tidal stages, when gravitational forces drive the flow. As stated by Araujo et al. (2005), the energy balance is often driven by the equilibrium between the production and dissipation of turbulent kinetic energy (TKE) near boundaries. Strong dissipation rates are associated with the surface and bottom boundary layers during spring tides and the less accentuated rates occur at inner regions of the flow. The regions of maximum TKE production and vertical diffusion are associated with different levels of maximum energy. 


\subsection{OBSERVATIONAL DATA}

\subsubsection{Field Experiment Planning and Preparations}

The experiments were organized as 2-day campaigns. Four distinct campaigns with varied conditions of geophysical forcing were associated with different fluxes (from 3000 to 9000 L.h-1), tides (spring and neap) and seasonal periods (summer and winter). As described in Table 1, the field work was executed during neap and spring tides for each period of summer/dry (December 2007) and winter/rainy and (July 2008) to represent the primary seasons at the region (Aragão, 2004). The sea experiments were completed during tidal stages that characterized the extremes of the dynamic situation - one slack water tidal period (high or low tidal stage) and one dynamic tidal period (flood or ebb tidal stage). The site for the experiments was determined considering the maximum depth that could provide good visibility in the water column, logistic viability and security. Following this criterion, an area of 30 meters depth was defined that is approximately $11 \mathrm{~km}$ from the Suape Harbor coastline.

Table 1. Campaigns carried out during the sea experiments.

\begin{tabular}{cccc}
\hline Period & Campaign & Tidal forcing & Date \\
\hline \multirow{2}{*}{ Summer } & C1 & Neap & Dec/17-18/2007 \\
& C2 & Spring & Dec/23-24/2007 \\
\hline \multirow{2}{*}{ Winter } & C3 & Spring & Jul/ 05-06/2008 \\
& C4 & Neap & Jul/10-11/2008 \\
\hline
\end{tabular}

The seasonal analysis is important due to the variation between the seasonal periods concerning the physical characteristics of the area. The highest temperatures are observed from December to February (Lins, 2002), which is during the dry period, and consequently the tide and evaporation increase the salinity at the surface. During the rainy period, heavy rains increase the continental runoff into the Suape Bay. Hence, suspended particulate matter (which determines turbidity) increases and reduces the water transparency. The tides are additionally observed due to 
the influence of the gravitational forces. The spring tide represents the tide of maximal range, while the neap tide usually resembles tidal ranges that are less than the mean tidal range.

Very few studies have been found in the literature involving analysis of gas plume evolution in coastal and tropical shallow waters. Because of this paucity of publications, information concerning methodology and field data collection was obtained from the literature, which has focused primarily on temperate deep waters (Rye et al., 1997; Johansen et al., 2003).

Three vessels were simultaneously used to achieve all of the planned activities during each field campaign (Figure 2). Vessel V1 was responsible for the gas injection into the sea floor, the submarine video camera recordings, and the diving staff. On board vessel V2, the data were collected for the thermohaline structures, and vessel V3 was used for the current meter settlement. A group of 12 scientists, operators and assistants participated in the field campaigns.

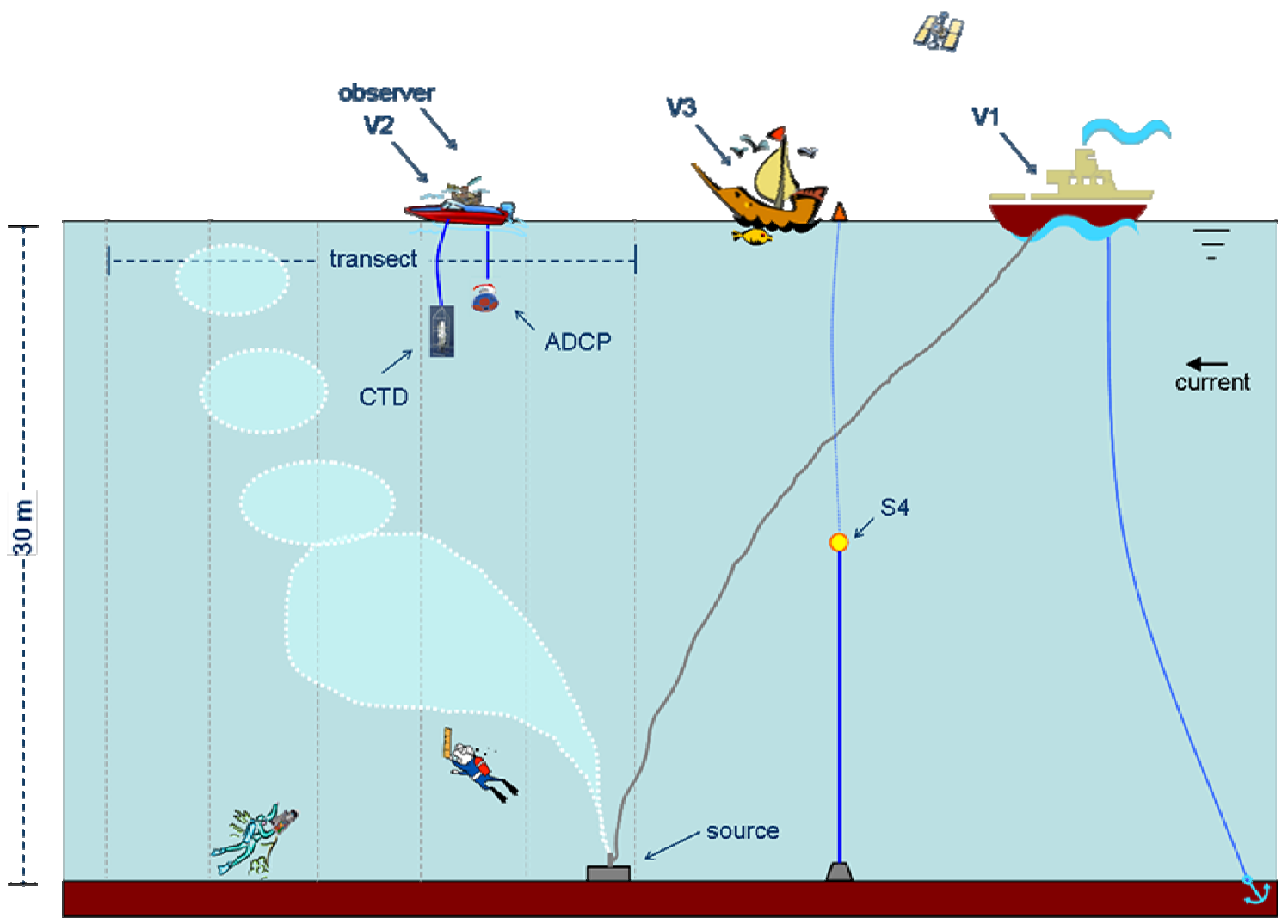

Figure 2. Schematic figure of field campaigns. 


\subsubsection{Gas Release Apparatus Arrangement}

The composition of Vehicular Natural Gas (VNG) is similar to that of methane, which in turn is the predominant gas from exploitation reservoirs. Because of that, as well as the VNG facility to acquire and manipulate, the release arrangement used three $7.5 \mathrm{~m}^{3} \mathrm{VNG}$ cylinders for the gas injection into the water.

The VNG was released from a device made especially for this purpose prior to the sea trial. The panel-like device consisted of two manometers and one rotameter with two simultaneous gas outlets. Each cylinder was connected to one manometer, which was hooked to the rotameter linked to a hose. First, the pressure was defined, and subsequently the gas flow was set to be released into the sea bottom. The outlet arrangement consisted of a U-shaped release pipe, which was anchored to a $20-\mathrm{kg}$ ballast, guiding the release almost vertically upwards. The diameter of the nozzle was $0.635 \mathrm{~cm}$, which was hooked to the ballast at $30 \mathrm{~m}$ depth. During the campaigns, the fluxes were released (exit conditions) through a 1/4-inch flexible hose at 3000 and 9000 L.h ${ }^{-1}$ (low and high flows, respectively), except for C1 campaign, for which the low flow was set to $6000 \mathrm{~L} \cdot \mathrm{h}^{-1}$.

\subsubsection{Video and Snapshot Camera Recordings}

The gas release from the bottom to the sea surface was recorded by a diver with a digital video camera (mod. Sony TRV130) in a waterproof case (mod. Croma-MR1). The camera had an "arm" attached in front of it with a depth gauge in its extremity. A second diver held a 1.4 meter ruler as a reference of size to later calculate the gas bubble plume's dimension.

To obtain relevant plume data, flows from 3000 to 9000 L.h-1 of natural gas were released outside of Suape Harbor, on the northeast coast of Brazil, at approximately $30 \mathrm{~m}$ deep over a time span of approximately 
15 minutes per release. The flow and the plume dimension were used to evaluate a numerical model for gas blowout.

\subsubsection{Sea Measurements}

The plume direction and dispersion are directly affected by the tide. Hence, the acquisition of current and wave data is important. Strong, cross-flowing currents tend to bend over the plume in the water column (Yapa et al., 2008a), and waves lead to the dispersion of the plume close to the surface. Therefore, obtaining thermodynamic data are also necessary because they are involved in the rise velocity of the gas plume in addition to the gas physicochemical processes because of the density difference between gas and water.

Field measurements were simultaneously performed to collect background information with $\mathrm{S} 4, \mathrm{ADCP}$ and CTD equipment, as well as video recordings of underwater plume evolution. The wave field characterization and the tide gauge measurements were obtained with the Interocean S4ADW-i Current Meter. This equipment was moored for 24 hours at half the mean depth water. Data were registered at $2 \mathrm{~Hz}$ sampling rate every three (two) hours in the summer (winter) period during periods of 30 minutes. The tide gauge data at this frequency allowed for the characterization of the temporal evolution of the highfrequency (wind-driven waves) and low-frequency (tide-driven waves) waves that occurred in the area during the campaigns. The sea level variation measured was compared to the tide forecast available from the Diretoria de Hidrografia e Navegação (Directorate of Hydrography and Navigation; DHN, 2007; 2008) of Brazilian Navy.

The current intensity and direction were obtained from the ADCP equipment (mod. Workhorse Rio Grande $600 \mathrm{kHz}$ ) configured for 80 levels, which correspond to the number of water profiling depth cells (WN) to cover the maximum expected water depth. Once a depth around 30 meters was defined for the study area, the sampling data with $\mathrm{WN}=80$ 
occur every $0.4 \mathrm{~m}$ along the water column. The ADCP was placed half a meter from the water surface, and two transects were done at the gas plume area. One cross section surveyed along a zigzag course, and the other cross section surveyed in a straight line with the purpose of comprising the plume area.

Thermodynamic data were obtained by the CTD equipment (mod. SBE-19plus Seacat Profiler) performing one vertical profile in the plume of rising droplets during each gas flow release. Generally, before the first gas flow release, two ADCP transects and one CTD profile were executed to be used as control data (with no gas release) for the hydrodynamic and thermodynamic surveys, respectively. Furthermore, the CTD data (salinity, temperature and density) were averaged in one-meter bins. All of the field work was georeferenced using two Global Positioning System devices (GPSs; mod. Garmin III-Plus and mod. GPSmap Garmin 298 Sounder).

\subsection{THE MODELING TOOLS}

A mathematical model was used for the forecasting and analysis of a gas plume evolution throughout the water column. It was formulated from a set of routines produced in computational code. The model's development was primarily based on theoretical propositions from Yapa and Zheng (1997). Following the usual framework and notations used in previous gas modeling, the nomenclature proposed by Friedl and Fanneløp (2000) was adopted as presented in Figure 3.

The model, GASOCEAN, is founded on the linear momentum balance of gas, seawater and oil (Chen and Yapa, 2004). The variation of mass inside the plume is provided considering the prime physicalchemical processes of water entrainment, gas dissolution and bubble separation process. The equations use a Lagrangian control volume approach for discretization. The plume evolution is calculated through the vertical displacement of this Lagrangian control volume along the ocean depth for each numerical time step. This displacement occurs due to the 


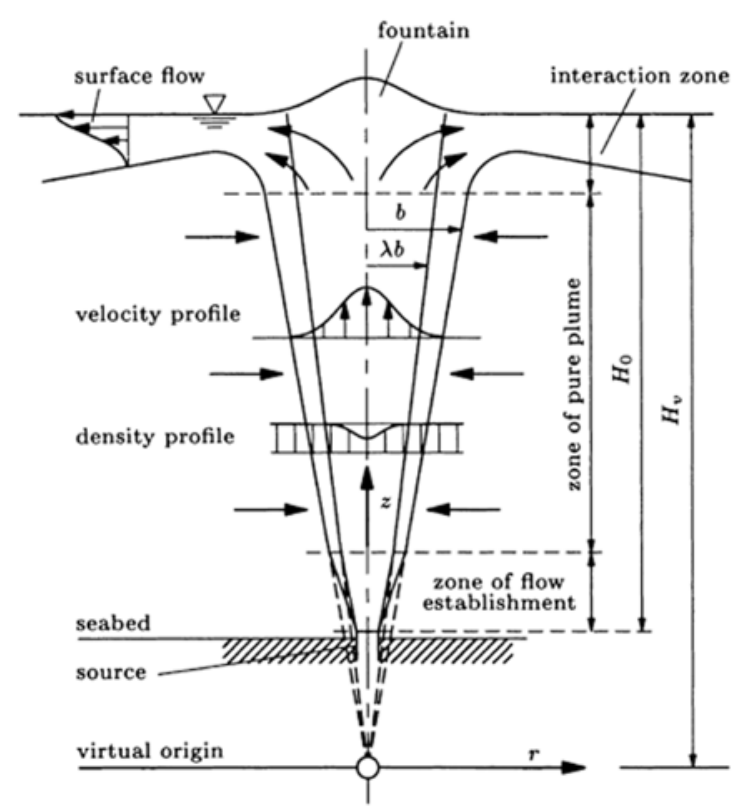

Figure 3. Bubble plume definition sketch adopted in the modeling (source: Friedl and Fanneløp, 2000).

non-linear features between the current velocity fields and the initial momentum of the plume.The position of the control volume along the simulation is obtained by the following equations:

$$
\mathrm{h}=|\mathrm{V}| \cdot \Delta \mathrm{t}
$$

and

$$
\Delta \mathrm{t}=0.1 \cdot \mathrm{b}_{0} /\left|\mathrm{V}_{0}\right|
$$

where $\mathrm{h}=$ the depth of the control volume $[\mathrm{m}] ;|\mathrm{V}|=$ the local plume velocity $\left[\mathrm{m} . \mathrm{s}^{-1}\right]$; and $\Delta \mathrm{t}=\mathrm{a}$ specified time step [s]. In Eq. (2), $\mathrm{b}_{0}=$ the ratio of the initial control volume $[\mathrm{m}]$ in contact with the sea bottom, which is obtained from the blowout release, and $\left|V_{0}\right|=$ the initial blowout velocity $\left[\mathrm{m} \cdot \mathrm{s}^{-1}\right]$.

The main equations used in this model describing the gas plume evolution are presented as follows and further detailed explanations may 
be found in Yapa's publications (Yapa and Zheng, 1997; Chen and Yapa, 2004). The momentum equations are applied to the average conditions in each control volume, taking into account the relative velocities between the gas and liquid:

$$
\begin{aligned}
& \frac{\mathrm{d}}{\mathrm{dt}}\left[\left(\mathrm{m}_{1}+\mathrm{m}_{\mathrm{b}}+\mathrm{m}_{\mathrm{h}}\right) \mathrm{u}\right]=\mathrm{u}_{\mathrm{a}} \rho_{\mathrm{a}} \mathrm{Q}_{\mathrm{e}}-\mathrm{u} \rho_{\mathrm{com}} \mathrm{Q}_{\mathrm{g}}, \\
& \frac{\mathrm{d}}{\mathrm{dt}}\left[\left(\mathrm{m}_{1}+\mathrm{m}_{\mathrm{b}}+\mathrm{m}_{\mathrm{h}}\right) \mathrm{v}\right]=\mathrm{v}_{\mathrm{a}} \rho_{\mathrm{a}} \mathrm{Q}_{\mathrm{e}}-\mathrm{v} \rho_{\mathrm{com}} \mathrm{Q}_{\mathrm{g}},
\end{aligned}
$$

The momentum equation in the vertical direction, with the incorporation of bubble ascending velocities relative to the slip (buoyant) velocity, is given by the following equation:

$$
\begin{aligned}
& \frac{\mathrm{d}}{\mathrm{dt}}\left[\mathrm{m}_{1} \mathrm{w}+\left(\mathrm{m}_{\mathrm{b}}+\mathrm{m}_{\mathrm{h}}\right)\left(\mathrm{w}+\mathrm{w}_{\mathrm{b}}\right)\right]=\mathrm{w}_{\mathrm{a}} \rho_{\mathrm{a}} \mathrm{Q}_{\mathrm{e}}-\mathrm{w} \rho_{\text {com }} \mathrm{Q}_{\mathrm{g}} \\
& +\left(\rho_{\mathrm{a}}-\rho_{\mathrm{l}}\right) \mathrm{g} \pi \mathrm{b}^{2}(1-\beta \varepsilon) \mathrm{h}+\left(\rho_{\mathrm{a}}-\rho_{\text {com }}\right) \mathrm{g} \pi \mathrm{b}^{2} \beta \varepsilon \mathrm{h},
\end{aligned}
$$

where $\mathrm{m}_{1}=$ the plume liquid mass $[\mathrm{kg}], \mathrm{m}_{\mathrm{b}}=$ the plume gas mass $[\mathrm{kg}], \mathrm{m}_{\mathrm{h}}=$ the mass of hydrates inside the plume $[\mathrm{kg}], \mathrm{u}=$ the horizontal plume velocity in the $\mathrm{x}$ direction $\left[\mathrm{m} \cdot \mathrm{s}^{-1}\right], \mathrm{u}_{\mathrm{a}}=$ the ambient horizontal velocity in the $\mathrm{x}$ direction $\left[\mathrm{m} \cdot \mathrm{s}^{-1}\right], \rho_{\mathrm{a}}=$ the density of the ambient seawater $\left[\mathrm{kg} \cdot \mathrm{m}^{-3}\right]$, which was obtained from the field data, $Q_{e}=$ the entrainment water flux $\left[\mathrm{m}^{3} \cdot \mathrm{s}^{-1}\right], \rho_{\text {com }}=$ the composite density of the hydrates and gas $\left[\mathrm{kg} \cdot \mathrm{m}^{-3}\right], \mathrm{Q}_{\mathrm{g}}=$ the gas flux $\left[\mathrm{m}^{3} \cdot \mathrm{s}^{-1}\right], \mathrm{v}=$ the horizontal plume velocity in the $\mathrm{y}$ direction $\left[\mathrm{m} . \mathrm{s}^{-1}\right]$ and $\mathrm{v}_{\mathrm{a}}=$ the ambient horizontal velocity in the $\mathrm{y}$ direction $\left[\mathrm{m} \cdot \mathrm{s}^{-1}\right]$, which was obtained from field data. For the vertical direction, $w=$ the plume vertical velocity $\left[\mathrm{m} \cdot \mathrm{s}^{-1}\right], \mathrm{w}_{\mathrm{a}}=$ the ambient vertical velocity $\left[\mathrm{m} \cdot \mathrm{s}^{-1}\right]$, $\mathrm{w}_{\mathrm{b}}=$ the gas bubble (or bubble slip) velocity $\left[\mathrm{m} \cdot \mathrm{s}^{-1}\right], \rho_{1}=$ the liquid density of the plume $\left[\mathrm{kg} \cdot \mathrm{m}^{-3}\right], \mathrm{g}=$ the acceleration due to gravity $\left[\mathrm{m}^{2} \cdot \mathrm{s}^{-1}\right], \mathrm{b}=$ the plume radius $[\mathrm{m}], \beta=$ the ratio between the cross-sectional areas occupied by the gas and that of the plume, and $\mathrm{h}=$ the control volume height $[\mathrm{m}]$, 
which ranges from 0.65 to 0.8 for vertical plumes (Yapa and Zheng, 1997). The gas bubble volume fraction inside the control volume, including hydrate shells, is represented by $\varepsilon=\left(\rho_{1}-\rho\right) /\left(\rho_{1}-\rho_{\text {com }}\right)$, where $\rho=$ the density of gas plume and liquid mixture $\left[\mathrm{kg} \cdot \mathrm{m}^{-3}\right]$.

The bubble slip velocity $\left(\mathrm{w}_{\mathrm{b}}\right)$ is intimately related to the sea temperature and its practically stable condition of relative density with the surroundings. According to some authors (Yapa and Zheng, 1997; Yapa et al., 1999; Zheng and Yapa, 2000), the vertical velocity difference between the gas and liquid inside a plume $\left(\mathrm{w}_{\mathrm{b}}\right)$ varies from 0.25 to $0.35 \mathrm{~m} \cdot \mathrm{s}^{-1}$. A gas bubble, which ranges in diameter from 1 to $10 \mathrm{~mm}$, affects the plume behavior as the slip velocity of gas bubbles (Zheng et al., 2002). In this study, the slip velocity for underwater releases was assumed to be 0.3 m.s. ${ }^{-1}$ as proposed by Yapa and Zheng (1997) and Johansen (2000).

The fate of the underwater plume is also determined by the entrainment process. As the plume rises through the water column, the ambient fluid enters through the outer surface of the plume. There are many models that use methods of constant coefficient, which need to change the coefficient based on the case under consideration. In this study we use the equations given in Yapa and Zheng (1997), which extended the formulations proposed by Lee and Cheung (1990) to account for 3D velocities. These equations do not require changing entrainment coefficients from case to case.

Lee and Cheung (1990) proposed that the entrainment is the combination of shear-induced entrainment and forced entrainment. The former, which is always present even with no ambient currents, occurs because of shear between the plume and the ambient fluid. The latter is considered when the advection of ambient fluid into the plume takes place. The equations resulted from the work of above authors are given below:

$$
\mathrm{Q}_{\mathrm{s}}=2 \pi \mathrm{bh} \alpha|| \overrightarrow{\mathrm{V}}\left|-\mathrm{V}_{\mathrm{a}}^{\prime}\right|,
$$


in which $\mathrm{Q}_{\mathrm{s}}=$ shear-induced entrainment, and $\alpha=$ entrainment coefficient.

$$
\begin{aligned}
\mathrm{Q}_{\mathrm{x}} & =\rho_{\mathrm{a}}\left|\mathrm{u}_{\mathrm{a}}\right|\left(\pi \mathrm{b} \Delta \mathrm{b}|\cos \varphi \cos \theta|+2 \mathrm{~b} \Delta \mathrm{s} \sqrt{1-\cos \theta^{2} \cos \varphi^{2}}\right. \\
& +\frac{\pi \mathrm{b}^{2}}{2}|\Delta(\cos \varphi \cos \theta)| \Delta \mathrm{t}, \\
\mathrm{Q}_{\mathrm{y}} & =\rho_{\mathrm{a}}\left|\mathrm{v}_{\mathrm{a}}\right|\left(\pi \mathrm{b} \Delta \mathrm{b}|\cos \varphi \sin \theta|+2 \mathrm{~b} \Delta \mathrm{s} \sqrt{1-\sin \theta^{2} \cos \varphi^{2}}\right. \\
& \left.+\frac{\pi \mathrm{b}^{2}}{2}|\Delta(\cos \varphi \sin \theta)|\right) \Delta \mathrm{t}, \\
\mathrm{Q}_{z} & =\rho_{\mathrm{a}}\left|\mathrm{w}_{\mathrm{a}}\right|\left(\pi \mathrm{b} \Delta \mathrm{b}|\sin \varphi|+2 \mathrm{~b} \Delta \mathrm{s}|\cos \varphi|+\frac{\pi \mathrm{b}^{2}}{2}|\Delta \sin \varphi|\right) \Delta \mathrm{t},
\end{aligned}
$$

where $Q_{x}, Q_{y}$ and $Q_{z}=$ forced entrainment components in $x, y$ and $z$, respectively, $\mathrm{u}_{\mathrm{a}}, \mathrm{v}_{\mathrm{a}}$ and $\mathrm{w}_{\mathrm{a}}=$ components of $\overrightarrow{\mathrm{V}}_{\mathrm{a}}, \theta=$ angle between the $\mathrm{x}$ axis and the plume projection on the horizontal plane, $\Delta x, \Delta y$ and $\Delta z=$ displacements of a control volume during one time step, which are found in $\Delta \mathrm{s}=\sqrt{\Delta \mathrm{x}^{2}+\Delta \mathrm{y}^{2}+\Delta \mathrm{z}^{2}}$.

Another implementation of the GASOCEAN model regards the gas dissolution mechanism in the plume's surroundings and the bubble separation process during the plume's ascension (Johansen, 2003; Zheng and Yapa, 2002). The gas dissolution process in the liquid environment is considered through the following expression (Zheng and Yapa, 2002):

$$
\frac{\mathrm{dn}}{\mathrm{dt}}=\mathrm{KA}\left(\mathrm{C}_{\mathrm{s}}-\mathrm{C}_{0}\right)
$$

in which $\mathrm{n}=$ the number of moles of gas in a bubble [mol]. $\mathrm{K}=$ the mass transfer coefficient $\left[\mathrm{m} . \mathrm{s}^{-1}\right], \mathrm{A}=$ the surface area of a gas bubble $\left[\mathrm{m}^{2}\right], \mathrm{C}_{\mathrm{S}}=$ the gas solubility (i.e., saturated value of $\mathrm{C}_{0}$ ) $\left[\mathrm{mol}^{-3}\right]$ and $\mathrm{C}_{0}=$ the dissolved gas concentration [mol. $\left.\mathrm{m}^{-3}\right]$. 
Based on Henry's Law, the concentration gradient across the bubble interface causes its dissolution. Accordingly, if the aqueous methane concentration of the plume enhances, the gradient decreases and slows the bubble dissolution (Leifer et al., 2006).

The gas slip velocity makes gas rise faster than the plume fluid. The whole trajectory of the bubbles may vary expressively because of this gas separation. The critical length represents the distance at which occurs the separation between the plumes of gas and oil. Its computation is done by comparing the momentum in the control-volume (gas and oil) with the horizontal momentum induced by environmental current fields.

The theoretical concept developed by Davidson and Pun (1999) and Davidson and Wang (2002) is applied for estimating the eventual separation between gas and oil plumes throughout the seawater column. This approach defines the excess momentum (per unit density - $\mathrm{M}_{0}$ ) of the mixture according to the environment forcing for each time step as follows:

$$
\mathrm{M}_{0}=\pi\left(\mathrm{U}_{0}-\mathrm{U}_{\mathrm{A}}\right) \mathrm{U}_{0} \mathrm{~b}_{0}^{2}
$$

where $\mathrm{M}_{0}=$ excess momentum in the control volume (gas and oil) $\left[\mathrm{m}^{4} \cdot \mathrm{s}^{-2}\right]$, $\mathrm{U}_{0}=$ initial velocity of the gas and oil mixture $\left[\mathrm{m} \cdot \mathrm{s}^{-1}\right]$, and $\mathrm{U}_{\mathrm{A}}=$ velocity of the currents in the ocean $\left[\mathrm{m} . \mathrm{s}^{-1}\right]$.

The characteristic length scale - $\mathrm{X}_{\mathrm{Sw}}[\mathrm{m}]$, which is calculated at each numerical time step, supplies an estimate of the transition point between the weakly advected and the strongly advected behavior. This scale relates to the excess momentum in the mixture (oil and gas) to the ocean momentum (always by units of density) and is represented by:

$$
\mathrm{X}_{\mathrm{SW}} \cong \frac{\mathrm{M}_{0}^{1 / 2}}{\mathrm{U}_{\mathrm{A}}}
$$


Experimental data reveal that plumes separation ( $\left.\mathrm{X}_{\mathrm{SEP}}\right)$ actually occurs when the excess momentum in the ambient fluid is about hundred-fold the momentum of the plumes, which means:

$$
\frac{\mathrm{X}_{\mathrm{SEP}}}{\left(\mathrm{M}_{0}^{1 / 2} / \mathrm{U}_{\mathrm{A}}\right)} \leq 100 \text {, }
$$

The variation (loss) of gaseous mass from the hydration and dissolution processes in the ambient water is given by the following equation:

$$
\frac{\mathrm{dm}_{\mathrm{b}}}{\mathrm{dt}}=-\mathrm{f} \cdot \mathrm{J} \cdot \tau \cdot\left(\frac{\mathrm{dn}}{\mathrm{dt}}+\frac{\mathrm{dn}_{\mathrm{s}}}{\mathrm{dt}}\right) \mathrm{M}_{\mathrm{g}},
$$

in which $\mathrm{dm}_{\mathrm{b}} / \mathrm{dt}=$ the gaseous mass loss due to hydration and dissolution $\left[\mathrm{kg} \cdot \mathrm{s}^{-1}\right], \mathrm{f}=\varepsilon$ is the gas fraction inside the control volume, $\mathrm{J}=$ the gas bubble flow inside the control volume [bubble $\left.\mathrm{n}^{\mathrm{o}} \cdot \mathrm{s}^{-1}\right], \tau=\Delta \mathrm{t}$ is the gas traveling time through the control volume $[\mathrm{s}], \mathrm{dn} / \mathrm{dt}=$ the hydrate formation tax $\left[\mathrm{mol}_{\mathrm{s}} \mathrm{s}^{-1}\right]$, and $\mathrm{dn}_{\mathrm{s}} / \mathrm{dt}=$ the gas dissolution tax regarding the gas bubble $\left[\mathrm{mol} . \mathrm{s}^{-1}\right] . \mathrm{M}_{\mathrm{g}}$ is the gas molecular weight $\left[\mathrm{kg} \cdot \mathrm{mol}^{-1}\right]$ according to the following equation:

$$
\mathrm{PM}_{\mathrm{g}}=\rho_{\mathrm{b}} \mathrm{ZRT},
$$

where $\mathrm{P}=$ the ambient pressure $[\mathrm{Pa}], \mathrm{Z}=$ the compressibility factor, $\mathrm{R}=$ the universal gas constant [8.31 J.mol.K] and $\mathrm{T}=$ the temperature $[\mathrm{K}]$.

The liquid mass conservation for each time step is computed by the equation below:

$$
\frac{\mathrm{dm}_{1}}{\mathrm{dt}}=\rho_{\mathrm{a}} \mathrm{Q}_{\mathrm{e}}-\mathrm{f} \cdot \mathrm{n}_{\mathrm{h}} \frac{\mathrm{dn}}{\mathrm{dt}} \mathrm{M}_{\mathrm{w}},
$$


where $\mathrm{dm}_{1} / \mathrm{dt}=$ the gaseous mass loss due to dissolution $\left[\mathrm{kg} \cdot \mathrm{s}^{-1}\right], \mathrm{n}_{\mathrm{h}}=$ the hydrate number (ex.: $n_{h}=6$ for $\mathrm{CH}_{4}$ ) and $\mathrm{M}_{\mathrm{w}}=$ the water molecular weight [kg. $\left.\mathrm{mol}^{-1}\right]$.

In the present simulations, the main component of the gaseous mixture considered was methane $\left(\mathrm{C}_{1}\right)$, which amounts to $94.2 \%$ of the released VNG. The ambient salinity, temperature, density and current velocity fields at each depth, obtained during the campaigns in the coastal region of the Suape Harbor industrial park area, were used to represent sea conditions in the routines of the gas plume model. Those forcings were used as the input data to the GASOCEAN model to simulate the evolution of the gas plume. Table 2 presents the constant values used in the simulations.

Table 2. Constant values used in model's simulations.

\begin{tabular}{ll}
\hline Parameter & Value \\
\hline Gas core width/jet diameter & 0.8 \\
Shear-induced entrainment coefficient & 0.083 \\
Orifice diameter & $0.00635 \mathrm{~m}$ \\
Bubble slip velocity & $0.3 \mathrm{~m} \cdot \mathrm{s}^{-1}$ \\
Initial bubble radius & $0.005 \mathrm{~m}$ \\
Molecular weight of gas & $0.017 \mathrm{~kg} \cdot \mathrm{mol}^{-1}$ \\
\hline
\end{tabular}




\section{Chapter 3}

\section{Experimental Set-Up and Field Data Acquisition}

\subsection{SUMMARY OF THE RESULTS}

This chapter aims to enhance the knowledge concerning subsurface gas blowouts in shallow tropical waters. This analysis occurred through the collection of seawater physical properties, in situ video registrations and hydrodynamic data during four sea experiments. The evolution of gas plumes in the water column was also observed from the bottom to the water surface. These experiments simulated distinct gas discharges (from 3000 to $9000 \mathrm{~L} . \mathrm{h}^{-1}$ ) at approximately $30 \mathrm{~m}$ depth (close to $15 \mathrm{~km}$ far from the coast) during neap/spring tides of different seasonal periods (summer/dry and winter/rainy). The data would additionally supply a baseline for model validation and fine-tuning. The methods used and the results obtained from this study are presented in this chapter. The main objective is to describe and document sea experiments regarding an accidental gas blowout in the Brazilian Continental Shelf by analyzing the evolution of the natural gas plume under the coastal hydrodynamics of the region. 
Results presented predominant transport toward the southsouthwest during the summer period and toward the northeast during the winter. Highest current intensities were observed during the winter spring tide. A vertical stratification could be observed during the summer season, differently from the winter, which registered a slight mixed water column. The thermohaline structure presented shallow clines during the winter period with the highest parameters values observed during the summer period. The difference in the plume width occurred mainly in the upper surface layer. The gas plume displaced toward the south-southwest (northeast-north) during the summer (winter) period. The gas flow releases seemed not to affect the local hydrodynamics. The plume movement was always influenced by the tidal and meteorological forcing.

The next Section of this chapter presents the manuscript entitled Field study of a simulated subsurface gas blowout in tropical and shallow water along the Brazilian coast, which was accepted in September $3^{\text {th }}$, 2012, and is available at the on-line journal Tropical Oceanography (http: / /www.ufpe.br/tropicaloceanography). 


\title{
3.2. PAPER
}

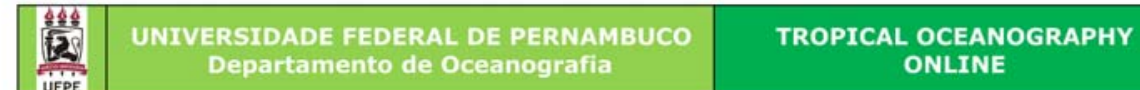

\section{ISSN: 1679-3013 \\ D.O.I.: 10.5914/to.2011.0071 \\ FIELD STUDY OF A SIMULATED SUBSURFACE GAS BLOWOUT IN TROPICAL AND SHALLOW WATER ALONG THE BRAZILIAN COAST}

\author{
Fabiana S. LEITE $^{1,2, *}$ \\ Moacyr ARAUJO ${ }^{1,2}$ \\ Marcus A. SILVA ${ }^{1,2}$ \\ Rodolfo A. SILVA ${ }^{1,2}$ \\ Pedro TYAQUICA ${ }^{2}$ \\ Enrique L. DROGUETT ${ }^{2}$
}

Recebido em: 20/05/2012

Aceito em: 03/09/2012

Although oil and gas exploration from the sea floor has experimented a rapid grow in the low latitude regions, very few gas blowout experiment in tropical and shallow waters has been published by the scientific community. This study aims to increase the knowledge concerning the gas behavior during a subsurface blowout in tropical shallow seawater. Field experiments were carried out by simulating a subsurface blowout with natural gas at approximately $30 \mathrm{~m}$ depth off Suape harbor, in the Northeast Brazilian coast. Four distinct scenarios with varied conditions of geophysical forcing were associated with different fluxes and seasonal periods. The methane fluxes released during the scenarios were set to 3,000 and 9,000 L.h ${ }^{-1}$ (low and high flows, respectively). During the austral summer were registered east-northeasterly winds with mean intensity of $7.2 \mathrm{~m} . \mathrm{s}^{-1}$. Significant wave heights were around $0.9 \mathrm{~m}$ propagating westward. Surface current intensities around $0.5 \mathrm{~m} . \mathrm{s}^{-1}$ with south-southwest direction; vertical stratification; gas plume displacement were registered toward south-southwest and plume width up to $2.7 \mathrm{~m}$ close to the surface. During the austral winter were observed winds blowing from the southeast with mean intensity of $6.6 \mathrm{~m} . \mathrm{s}^{-1}$. Significant wave heights were around 1.6 $\mathrm{m}$ propagating northwestward. Similar summer current intensities were toward the northeast. A slight mixed water column was registered. Gas plume width was higher than $1.3 \mathrm{~m}$ close to the surface and presented a northeast-northward displacement. The gas plume movement was always influenced by the tidal and meteorological forcings, in that order. Difference in the plume width occurred mainly in the upper surface layer and current measurements indicated that the gas bubbles do not affect the local hydrodynamics.

Key words: Experimental data, Natural gas, Underwater blowout, Tropical Atlantic.

\section{RESUMO}

Apesar da exploração marinha de óleo e gás ter experimentado um rápido crescimento em regiões de baixa latitude, poucos experimentos em águas rasas tropicais têm sido publicados pela comunidade científica. Este estudo foi desenvolvido com o objetivo de incrementar o conhecimento acerca do comportamento de uma pluma de gás natural durante um vazamento acidental em águas rasas tropicais. Experimentos de campo foram realizados através da reprodução in situ de um vazamento de gás natural a aproximadamente $30 \mathrm{~m}$ de profundidade ao largo do Porto de Suape, na costa nordeste do Brasil. Quatro cenários distintos foram associados a diferentes fluxos de gás e períodos sazonais. Os fluxos de gás liberados durante os cenários foram configurados

1. Laboratory of Physical and Coastal Oceanography at the Oceanography Department (LOFEC/DOCEAN), Federal University of Pernambuco, Av. Arquitetura, s/n, Cidade Universitária, 50740-550, Recife - PE, Brazil.

2. Center for Risk Analysis and Environmental Modeling (CEERMA), Federal University of Pernambuco, Av. Arquitetura, s/n, Cidade Universitária, 50740-550, Recife - PE, Brazil. E-mails: fasoaresl@yahoo.ca; moa@ufpe.br; marcus@ufpe.br; rodolfoas@hotmail.com; ealopez@uol.com.br. 
LEITE, F. S. et al. Field study of a simulated subsurface gas blowout in tropical and shallow water along the Brazilian Coast.

para 3.000 e 9.000 L.h $^{-1}$ (vazões baixa e alta, respectivamente). Durante o verão austral foram registrados ventos de leste-nordeste com intensidade média de $7,2 \mathrm{~m} . \mathrm{s}^{-1}$; altura significativa das ondas por volta de $0,9 \mathrm{~m}$ propagando-se para oeste; intensidade de corrente na superfície de aproximadamente $0,5 \mathrm{~m} \cdot \mathrm{s}^{-1}$ com direção sul-sudoeste; estratificação vertical; deslocamento das plumas na direção sul-sudoeste e largura das plumas de até $2,7 \mathrm{~m}$ perto da superfície. Durante o inverno austral foram observados ventos de sudeste com intensidade média de $6,6 \mathrm{~m} \cdot \mathrm{s}^{-1}$; altura significativa das ondas por volta de $1,6 \mathrm{~m}$ propagando-se para noroeste; intensidades de corrente superficiais similares às do verão direcionando-se para nordeste; uma coluna d'água levemente misturada; plumas de gás com largura maior do que $1,3 \mathrm{~m}$ próximo à superfície e deslocamento para nordeste-norte. O movimento das plumas foi influenciado pelas forçantes de maré e meteorológica, nesta ordem. A diferença no diâmetro da pluma ocorreu principalmente na camada mais próxima à superfície. As medições de correntes indicaram que as bolhas de gás não afetam a hidrodinâmica local.

Palavras chave: Dados experimentais, Gás natural, Vazamentos submarinos, Atlântico tropical.

\section{INTRODUCTION}

Oil and gas exploration and exploitation from the sea floor has been a growing and lucrative activity around the world. With this growth, the possibility of an accidental oil/gas release increases and consequently rises the need for a better understanding of the evolution (and dimensions) of oil/gas plumes in seawater. More specifically, it is important to know where, when and how much gas will reach the surface. This motivation requires realistic descriptions of blowout scenarios through in situ experiments. Furthermore, as a part of contingency planning, these experiments would provide baseline data for the calibration and validation of computational models developed to describe subsurface plume behavior (e.g., RYE et al., 1997; YAPA et al., 1999; CHEN and YAPA, 2002; JOHANSEN et al., 2003).

Gas expands as it rises along water depth because of the pressure decrease and thus increases the buoyancy of the jet/plume (ZHENG et al., 2002). There are many differences between deep and shallow water blowouts (ZHENG et al., 2002). In deep water blowouts the gas hydrate formation and decomposition occur due to the high pressure and low temperature, as well as gas dissolution when the water layer is deep. For blowouts at shallow to moderate depths, the gas dissolution from rising bubbles into seawater may be negligible and no hydrates are observed (JOHANSEN, 2000).

In situ natural gas releasing experiments are expensive and demand logistical planning because they require manpower, equipment and vessels. Furthermore, these experiments are dangerous because methane gas clouds can generate explosions (FISCHER, 1982; JOHANSEN et al., 2003; BEEGLE-KRAUSE and LYNCH, 2005). The major concerns from accidental gas and oil blowouts are not only explosion/fire (CHEN and YAPA, 2002). Other factors include the toxicity risks to humans and to the environment, and the commitment of ship buoyancy due to the density decrease caused by the oil/gas mixture. As a consequence very few in situ experiments have been reported in the literature, and most of them have been carried out in high latitude/deep water situations (BREWER et al., 1997; RYE et al., 1997; JOHANSEN et al., 2003).

Brewer et al. (1997, 1998), for example, investigated the process of methane hydrate formation in experiments conducted during January 1996 at the depth of $910 \mathrm{~m}$ in Monterey Bay, USA. The authors supplied a remotely operated vehicle (ROV) with a methane gas tank, two types of sediment and four samplers, while ambient seawater pressure and temperature were registered. They concluded that the formation of hydrates is rapid in seawater and that the sediment type is important for the hydrate formation pattern. Rye et al. (1997) performed an in situ experiment with air and oil subsurface release at $106 \mathrm{~m}$ during June 1996 in the North Sea. They reproduced different blowout conditions and monitored the plume and the resulting surface oil slick. Remote sensing of the surface slick was obtained, and Metocean buoys, CTD 
LEITE, F. S. et al. Field study of a simulated subsurface gas blowout in tropical and shallow water along the Brazilian Coast.

(conductivity, temperature, depth) and ROV were used. Measurements were applied for improving blowout models. The authors observed that the sampling methodology was appropriated and that the model showed good agreement with sea observations. Real and modeled plume presented the same proportions, although the size of the slick at the sea surface was overestimated by the model.

The experiment performed by Bulatov et al. (2002) was based on gas plume detection by microwave remote sensing methods without attention to the physical conditions of the plume. The experiment was executed during 2000/2001 using compressed air in the Black Sea. The authors observed that radar images of the perturbed zone presented great polarization dependence and concluded that microwave remote sensing is effective for detecting underwater gas pipe leakage.

The DeepSpill set of experiments were also carried out by Johansen et al. (2001, 2003) during June 2000 at a depth of $844 \mathrm{~m}$ in the Norwegian Sea. The main goals of these experiments were to obtain high-quality data from a deep water oil/gas release and to use them to calibrate deep water plume models (CHEN and YAPA, 2002). They also intended to explore alternative methods to track the oil plume. For the trials, the authors used ROVs, echo sounders, an ADCP (acoustic Doppler current profiler), a CTD and a rosette, in addition to boats, vessels and airplanes. The results indicated that the gas had dissolved entirely by $150 \mathrm{~m}$ beneath the surface, and no gas hydrates were formed. Furthermore, the oil reached the surface a few hundred meters from the blowout source about one hour after the initial release.

In this paper we present a comprehensive data set of geophysical and gas release measurements obtained from in situ experiment carried out off Northeast of Brazil. These measurements are expected to enhance the knowledge concerning gas blowouts in shallow tropical waters, supplying baseline data for blowout model calibration and validation. Hydrological and hydrodynamic data were collected during distinct seafloor gas plume releases at approximately $30 \mathrm{~m}$ depth. Measurements were conducted during neap/spring tides of summer/dry and winter/rainy periods. It was expected that the gas plume would quickly rise to the surface following the local hydrodynamics and that gas entrainment would be the major process acting on the plume evolution. The paper is structured as follows: a detailed description of the experimental set-up is provided in the Material and Methods Section; the measurements obtained during the experiments are described in the Results and Discussion Section. Finally, the primary conclusions and recommendations are presented in the Conclusion Section.

\section{MATERIAL AND METHODS}

\section{Study Area, Planning and Preparations}

The field work is comprised of in situ observation of a natural gas plume throughout the water column in the coastal region near the Suape Harbor industrial park area, Pernambuco, Brazil. According to the Köppen-Geiger climate classification scheme (PEEL et al., 2007), the climate is warm and humid (type Am) in the region. Two well-defined seasons are observed, which are the dry season (from September to March) and the rainy season (from April to August). The average annual rainfall is $1,500 \mathrm{~mm}$, and the evaporation is $1,200 \mathrm{~mm}$. According to Araujo et al. (2005), semidiurnal tides occur at Suape with a mean spring (neap) range of $2.2 \mathrm{~m}(1.1 \mathrm{~m})$. The southeasterly trade winds are predominant throughout the year, oscillating from the east and the northeast during summer (LINS, 2002).

A weak thermocline (halocline) occurs near the surface as a result of solar radiation (evaporation) during the day. Below this region, a well-mixed and homogeneous flow has been observed. The current intensity indicates the influence of momentum exchange near the surface and bottom boundary layers (ARAUJO et al., 2005). According to the upper flow structures, the authors observed strong surface variations in the current intensity and direction, which were associated with slack waters, when the wind effects were more pronounced. The authors also noticed weak wind shear effects near the surface that were associated with strong bottom variations in current direction during the 
LEITE, F. S. et al. Field study of a simulated subsurface gas blowout in tropical and shallow water along the Brazilian Coast.

dynamic tidal stages, when gravitational forces drive the flow. As stated by Araujo et al. (2005), the energy balance is often driven by the equilibrium between the production and dissipation of turbulent kinetic energy (TKE) near boundaries. The stronger dissipation rates are associated with the surface and bottom boundary layers during spring tides, and the less accentuated rates occur at inner regions of the flow. The regions of maximum TKE production and vertical diffusion are associated with different levels of maximum energy.

The experiments were planned as two-day campaigns. The site for the experiments was determined considering the maximum depth that could provide good visibility in the water column, logistic viability and security. Following this criterion, an area of 30 meters depth was defined that is approximately $11 \mathrm{~km}$ from the coastline of Cabo de Santo Agostinho (Fig.1).

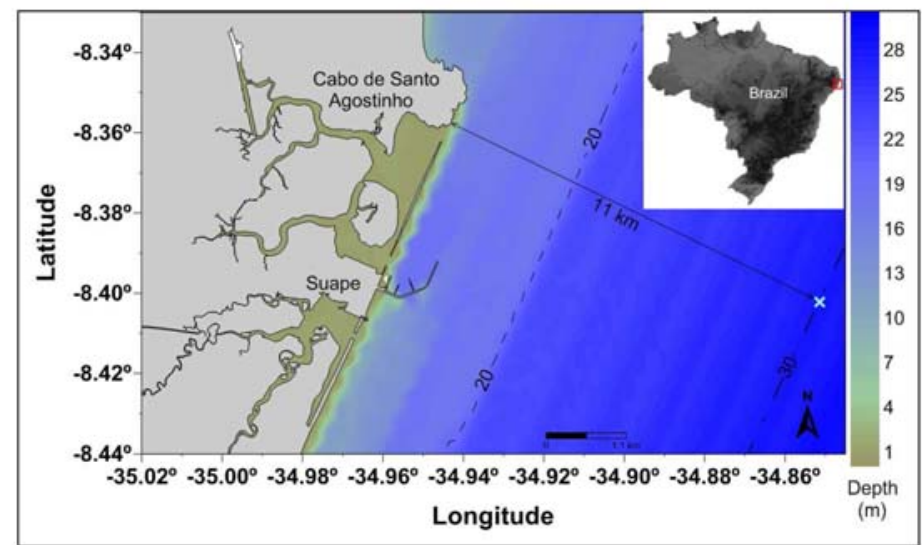

Figure 1 - Localization map in the coastal region of the Suape Harbor, Pernambuco, Brazil, presenting the experimental station $(x)$, located $11 \mathrm{~km}$ away from the coastline (solid line). Isobaths of $20 \mathrm{~m}$ (dashed line) and $30 \mathrm{~m}$ (dashdotted line) are also plotted (SILVA, 2004).

The campaigns (referred to as $\mathrm{C} 1, \mathrm{C} 2, \mathrm{C} 3$ and $\mathrm{C} 4$ - see Tab. 1) were planned with the intent to: (i) characterize the evolution of hydrocarbons plumes in the water column during distinct seasonal and dynamic situations; and (ii) determine the existence of hydrodynamic forcing during the dry and rainy seasons for the neap and spring tides.

Table 1 - Summary of the sea campaigns.

\begin{tabular}{c|c|c|c}
\hline Period & Campaign & Tidal forcing & Date \\
\hline \multirow{2}{*}{ Summer } & C1 & Neap & $12 / 17-18 / 2007$ \\
\cline { 2 - 4 } & C2 & Spring & $12 / 23-24 / 2007$ \\
\hline \multirow{2}{*}{ Winter } & C3 & Spring & $07 / 05-06 / 2008$ \\
\cline { 2 - 4 } & C4 & Neap & $07 / 10-11 / 2008$ \\
\hline
\end{tabular}

The field work was executed during neap and spring tides for each period of summer/dry (December 2007) and winter/rainy and (July 2008) to represent the primary seasons of the region (ARAGÃO, 2004). It was completed during tidal stages that characterized the extremes of the dynamic situation - slack water tidal period (high or low tidal stage) and dynamic tidal period (flood or ebb tidal stage).

This analysis is important due to the discrepancy between the seasonal periods concerning the physical characteristics of the area. The highest temperatures are observed from December to February (LINS, 2002), which correspond to the dry period, and consequently tides and evaporation increase the salinity at the surface. During the 
LEITE, F. S. et al. Field study of a simulated subsurface gas blowout in tropical and shallow water along the Brazilian Coast.

rainy period, heavy rains increase the continental runoff into the Suape Bay. Hence, the suspended particulate matter (i.e., the turbidity) increases and reduces the water transparency. The tides are additionally observed due to the influence of the gravitational forces. The spring tide represents the maximum tidal range, while the neap tide usually resembles tidal variations that are less than the mean tidal range.

Three vessels were simultaneously used to achieve all of the planned activities during each field campaign. Vessel V1 was responsible for the gas injection into the sea floor, the submarine video camera recordings and the diving staff. On board vessel V2, the data were collected for the thermohaline structures, and vessel V3 was used for the current meter settlement. A group of 12 scientists, operators and assistants participated in the field campaigns. Figure 2 shows the main activities during the subsurface blowout field experiment.

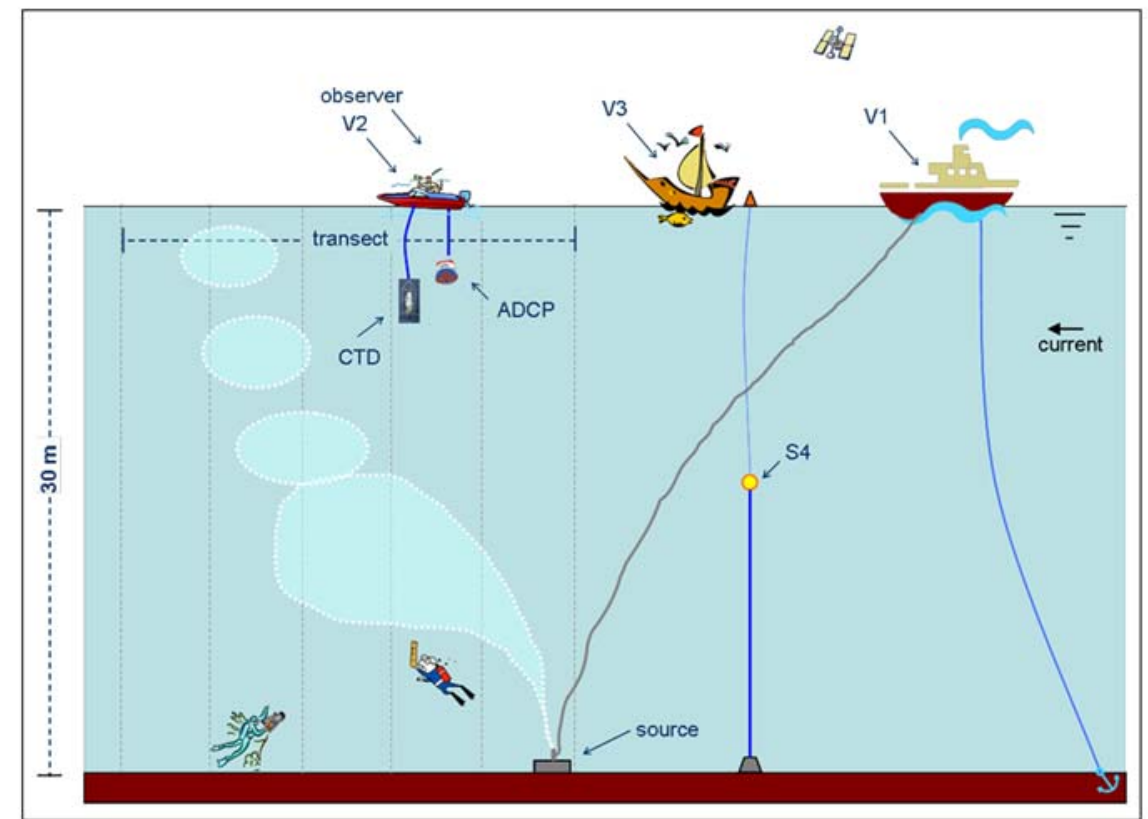

Figure 2 - Logistic scheme of the field campaigns.

\section{Release Arrangement}

Vehicular Natural Gas (VNG) was used because it is easy to acquire and to manipulate. The similarity between the composition of VNG and that of methane predominant gas from the exploitation reservoirs in the ocean was also important for this choice.

Three $7.5 \mathrm{~m}^{3}$ VNG cylinders (Fig. 3) were obtained for the gas injection into the water. The VNG was released from a device made especially for this purpose prior to the sea trial. This device was panel-like, with two simultaneous gas outlets, and consisted of two manometers and one rotameter. Each cylinder was connected to one manometer which was hooked to a rotameter linked to a hose. First, the pressure was defined and, subsequently, the gas flow was set to be released into the sea bottom. The outlet arrangement consisted of a U-shaped release pipe, which was moored to a $20 \mathrm{~kg}$ ballast, which directed the release almost vertically upwards. The diameter of the nozzle was $1 / 4$ of an inch, which was hooked to the ballast at $30 \mathrm{~m}$ depth. The gas was pumped down and transported as pressurized gas to the release platform through a $1 / 4$-inch flexible 
LEITE, F. S. et al. Field study of a simulated subsurface gas blowout in tropical and shallow water along the Brazilian Coast.

hose. The fluxes released (exit conditions) during the scenarios were set to 3,000 and 9,000 L.h. ${ }^{-1}$ (low and high flows, respectively), except for campaign C1, for which the low flow was set to 6,000 L.h.'

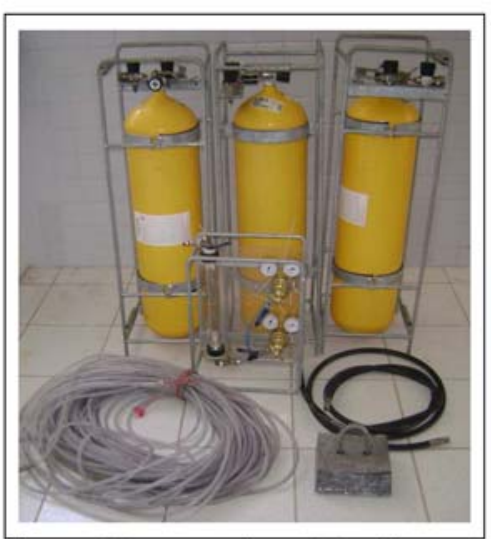

Figure 3 - Set of used equipment for gas release into the sea bottom.

\section{Video and Snapshot Camera Recordings}

The gas release from the bottom to the sea surface was recorded by a diver with a digital video camera (mod. Sony TRV130) in a waterproof case (mod. Croma-MR1). The camera had an "arm" attached in front of it with a depth gauge in its extremity. A second diver held a 1.4 meter ruler as a reference of size to later calculate the gas bubble plume dimension.

In order to obtain relevant plume data, flows from 3,000 to 9,000 L.h ${ }^{-1}$ of natural gas were released at approximately $30 \mathrm{~m}$ deep over a time span of approximately 15 minutes per release.

\section{Sea Measurements}

The plume direction and dispersion are directly affected by the tides; therefore the acquisition of current and wave data are important. Strong, cross-flowing currents tend to bend over the plume in the water column (YAPA et al., 2008), and waves lead to the dispersion of the plume close to the surface. Therefore, obtaining thermodynamic data are also necessary because they are involved in the rise velocity of the gas plume in addition to the gas physicochemical processes because of the density difference between gas and water.

Field measurements were carried out to collect background information, such as CTD, ADCP and S4 current meter data. The current intensity and direction were obtained with the ADCP equipment (mod. Workhorse Rio Grande $600 \mathrm{kHz}$ ), which was configured for $\mathbf{8 0}$ levels. Such levels correspond to the number of water profiling depth cells (WN) to cover the maximum expected water depth. Once the study area was defined to be around 30 meters depth, the $\mathrm{WN}=80$ results on current measurements every $0.4 \mathrm{~m}$ along the water column. The ADCP was placed half a meter from the water surface, and two transects were taken at the gas plume area. One cross section surveyed along a zigzag course, and the other cross section surveyed in a straight line with the purpose of comprising the plume area.

Thermodynamic data from the area were acquired by the CTD equipment (mod. SBE-19plus Seacat Profiler). Generally, before the first gas flow release, two ADCP transects and one CTD profile were completed to be used as control data (with no gas release) for the hydrodynamic and thermodynamic surveys, respectively. Subsequently, one vertical CTD profile was obtained directly from the plume of rising droplets after two 
LEITE, F. S. et al. Field study of a simulated subsurface gas blowout in tropical and shallow water along the Brazilian Coast.

current meter transects during each gas flow release. Furthermore, the CTD data (salinity, temperature and density) were averaged in one-meter bins.

The wave field characterization and the tide gauge measurements were completed with the Interocean S4ADWi Current Meter. This equipment was moored for 24 hours at half the mean water depth. The current meter data were sampled at a rate of $2 \mathrm{~Hz}$ for periods of 30 minutes every three (two) hours in the summer (winter) period. The tide gauge data at $2 \mathrm{~Hz}$ frequency allowed for the characterization of the temporal evolution of low-frequency (tide-driven waves) and high-frequency waves (wind-driven waves) that occurred in the area during the campaigns. All of the field work was georeferenced using two Global Positioning System devices (GPSs; mod. Garmin III-Plus and mod. GPSmap Garmin 298 Sounder). The sea level variation was measured and compared to the tide forecast available from the Diretoria de Hidrografia e Navegação (Directorate of Hydrography and Navigation; DHN, 2007; 2008) of Brazilian Navy.

\section{RESULTS AND DISCUSSION}

Oceanographic data were obtained during the field campaigns with the purpose of enhancing the knowledge regarding gas blowouts in a prosperous gas/oil-producing tropical region.

\section{Wind Stress}

Wind forcing has been known to strongly influence gas transfer over the global ocean (WANNINKHOF et al., 2009) in addition to near-surface turbulence (ZAPPA et al., 2007). The wind fluctuation in the study area occurs on the scale of minutes, hours, days, weeks and months. Wind measurements obtained from the meteorological station of Porto de Galinhas $\left(8.511^{\circ} \mathrm{S}, 35.003^{\circ} \mathrm{W}\right)$ at $10 \mathrm{~m}$ height, which is located $15 \mathrm{~km}$ south of the study area, were used to define the wind effect during the field campaigns. Figure 4a-b shows the seasonal-averaged wind data (2000 to 2005) at Porto de Galinhas, indicating that more intense and frequent winds come from southeast-east, with a mean intensity close to $7.0 \mathrm{~m} \cdot \mathrm{s}^{-1}$.

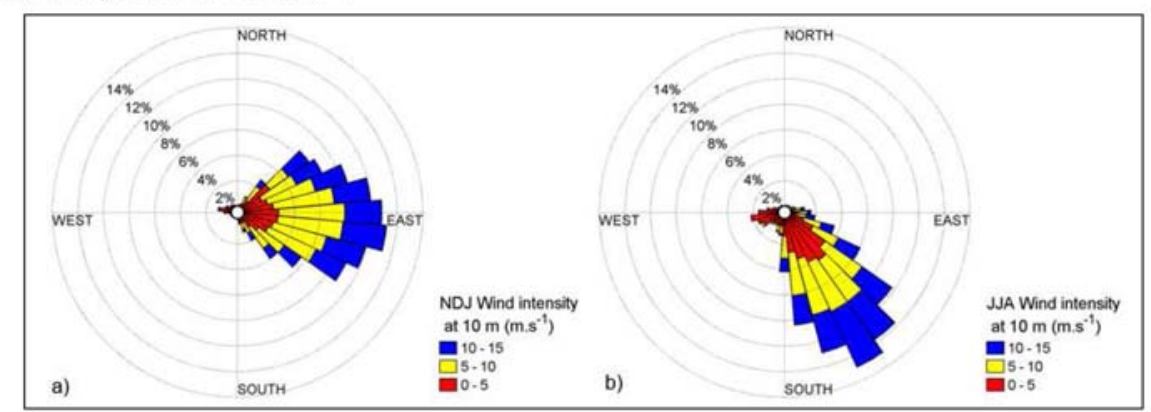

Figure 4 - Seasonal-averaged wind for: (a) summer period (NDJ means November to January); and (b) winter period (JJA means June to August) measured at 10 meters high in the Porto de Galinhas' meteorological station.

The mean direction is from the east-northeast from November to January (Fig. 4a), presenting mean intensity of $7.2 \mathrm{~m} . \mathrm{s}^{-1}$; and from the southeast during the period from June to August (Fig. 4b) with mean wind intensity of $6.6 \mathrm{~m} \cdot \mathrm{s}^{-1}$. Therefore, the prevailing winds change direction when they are influenced by an important meteorological system. As reported by Lins (2002), the southeasterlies prevail during the entire year, switching between east and northeast directions in summer periods.

According to Wunsch (2002) and numerous other studies, the upper layers of the ocean are driven by the wind and the top hundred meters of the mass flux is directly sustained by the wind stress. Considering the shallow depth of the field experiment, it is reasonable to expect this scenario to occur. However, because the site is near to the 
LEITE, F. S. et al. Field study of a simulated subsurface gas blowout in tropical and shallow water along the Brazilian Coast.

coast, the tide also has great control over the local dynamics. This tidal control possibility is also stated by Wunsch (2002), who observed that the mass flux of the ocean is controlled primarily by the wind and secondarily by the tidal forcing.

The wind effect over the natural gas amplifies its dissipation into the atmosphere. Regarding a low to moderate (below $10 \mathrm{~m} \cdot \mathrm{s}^{-1}$ ) mean wind velocity, LeNeveu (2011) explained that, in general, the atmospheric concentrations of a gas are higher and less reliable at low wind speeds. This uncertainty can be dealt with probabilistic risk assessment.

\section{Wave Field}

The characteristics of high frequency surface waves result from the direct wind action and the interaction between the wave and the sea bottom, once these waves lead to the dispersion of the plume close to the surface. According to Wanninkhof et al. (2009), they have found a great intensification of gas fluxes caused by breaking waves and bubble entrainment. Additionally, Bock et al. (1999) found a reasonable correlation between the gas transfer velocity and short wind waves. However, despite the fact that the wave field strongly affects gas exchange, it is not yet possible to accurately quantify the effect of breaking waves on this exchange (WANNINKHOF et al., 2009).

With the primary purpose of observing the wave field, the S4ADWi current meter was deployed for $24 \mathrm{~h}$ on December $20^{\text {th }}, 2007$ (summer period campaigns) and July $5^{\text {th }}$, 2008 (winter period campaigns). Registered data from the S4ADWi were used to generate frequency diagrams of the significant wave height $\left(H_{s}\right)$, wave propagation direction $\left(\theta_{\mathrm{s}}\right)$ and significant period $\left(T_{s}\right)$. Significant wave height is defined as the mean wave height of the highest third of the waves. $\theta_{\mathrm{s}}$ is referenced by true north (zero degrees), increasing clockwise.

During the summer period, significant wave heights were registered between 0.7 to $1.0 \mathrm{~m}$, propagating in a bimodal direction of 210 and 320 degrees (mainly westward). These waves presented a significant period of 6.5 to 6.7 seconds. Waves with $\mathrm{H}_{\mathrm{s}}$ between 1.2 and $1.8 \mathrm{~m}$ were observed in this area during the winter period. These waves propagated mainly between 315 and 350 degrees (often northwestward) and presented a significant period of 7.0 to 7.4 seconds. These results are in agreement with the current observations that were performed by the ADCP equipment. They reveal the seasonal distribution of the prevailing winds at the Suape Harbor coastal region as previously described in the wind stress section.

\section{Current Measurements}

The current data obtained during the summer and winter periods are respectively shown in Figures 5 and 6 . It is expected that the cross-shore currents during dynamic tidal stages and the wind effects of different periods would influence the bending of the gas plume.

The data obtained during the field campaigns were submitted to a $95 \%$ confidence interval calculation, which aided in determining a statistically consistent representation of the field data. The results of this analysis are shown in the following sections.

\section{Summer period}

The summer season is represented by the first two field campaigns, which are described hereafter. According to the current data acquired during the neap ebb tide (Fig. $5 a$ ), the current direction prevailed southward throughout the water column, with the exception of the bottom layer with no gas release (the control data), which presented a southwest direction. Slightly higher mean current intensities for this first field campaign were observed when the lowest $\left(6,000 \mathrm{~L} \cdot \mathrm{h}^{-1}\right.$ or $\left.0.1 \mathrm{~m}^{3} \cdot \mathrm{min}^{-1}\right)$ gas flow was released (maximum mean values at the surface of approximately $0.6 \mathrm{~m} . \mathrm{s}^{-1}$ ). Compared to the control data, the hydrodynamics did not show any highlighted differences in the current velocities and directions. This initial campaign had many mishaps, and because of that, it 
LEITE, F. S. et al. Field study of a simulated subsurface gas blowout in tropical and shallow water along the Brazilian Coast.

was not possible to obtain hydrodynamic and thermodynamic data from the slack water tidal period.

For the spring tide period, the current directions were predominantly southwestward. However, other current directions were also registered, excluding those northward and northeastward. The mean current intensities were stronger during the flood tidal stage, reaching up to $0.7 \mathrm{~m} . \mathrm{s}^{-1}$ at the surface during the high flow release $\left(9,000\right.$ L. h $^{-1}$ or $\left.0.15 \mathrm{~m}^{3} \cdot \mathrm{min}^{-1}\right)$.

During low tide (Fig. 5b), the three sets of current data (the control data and the low and high releases) presented different directions, which were southwestward, southward and southeast-eastward, respectively. The only altered behavior along the water column occurred at the bottom layer with no gas release, which showed a low mean northwestward intensity. The highest mean current intensity (approximately 0.5 $\mathrm{m} . \mathrm{s}^{-1}$ ) was observed during the $9,000 \mathrm{~L} . \mathrm{h}^{-1}$ flow release. The exception was at the bottom layer velocity, which was higher at the $3,000 \mathrm{~L} \cdot \mathrm{h}^{-1}\left(0.05 \mathrm{~m}^{3} \cdot \mathrm{min}^{-1}\right)$ release $\left(0.1 \mathrm{~m} \cdot \mathrm{s}^{-1}\right)$, followed by the highest flow.

At the moment of the flood tidal stage (Fig. 5c), the predominant direction was southwestward followed by the westward direction. The most intense currents were observed during the high flow release (approximately $0.7 \mathrm{~m} . \mathrm{s}^{-1}$ ), with the exception of the bottom layer. This layer later presented a high mean value of $0.2 \mathrm{~m} \cdot \mathrm{s}^{-1}$ during the low flow $\left(3,000 \mathrm{~L} . \mathrm{h}^{-1}\right)$ release northwestward. 
LEITE, F. S. et al. Field study of a simulated subsurface gas blowout in tropical and shallow water along the Brazilian Coast.

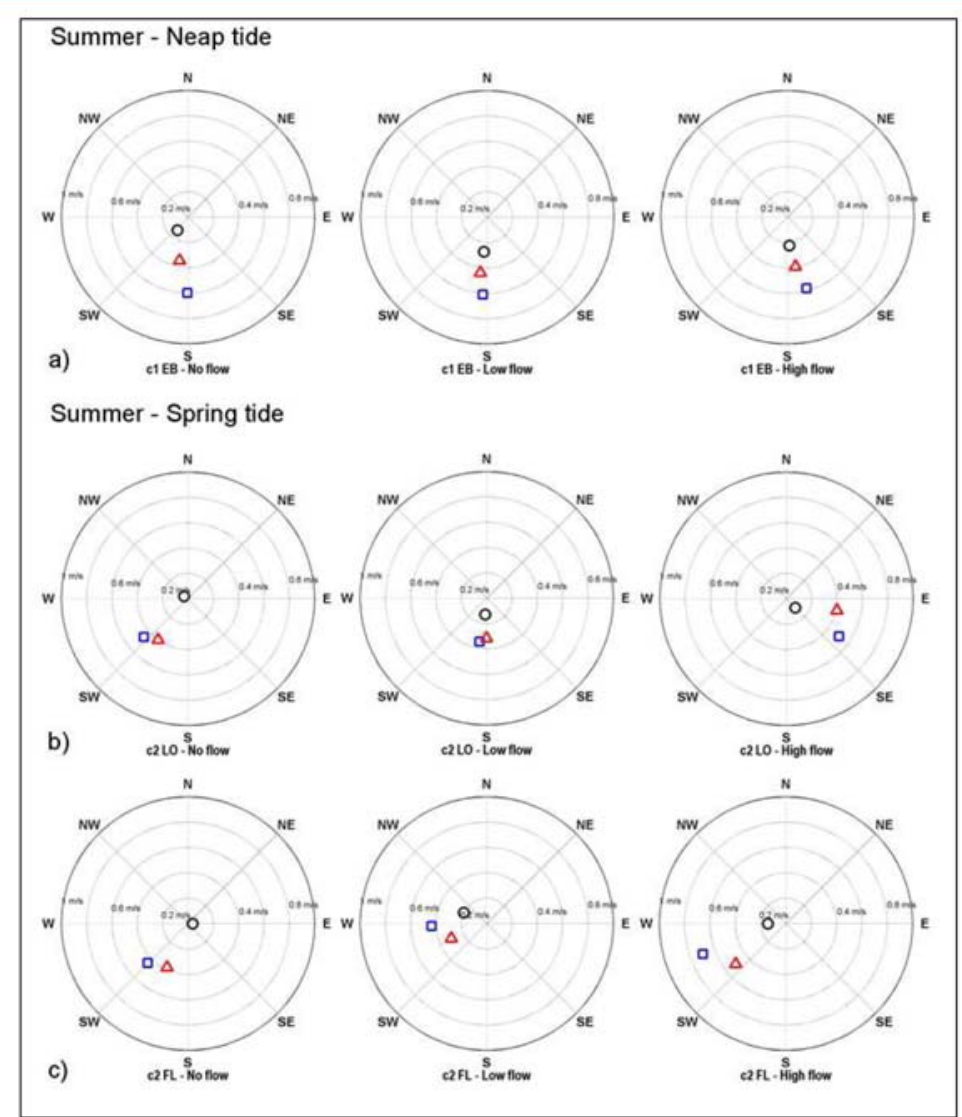

Figure 5 - Polar plots of the summer mean velocity current values for the surface ( $\square$ ), middle $(\Delta)$ and bottom $(O)$ of the water column during (a) the neap ebb tide, (b) the spring low tide and (c) the spring flood tide.

\section{Winter period}

During the third campaign (Fig. 6a), data were only collected for the spring low tide due to rough sea conditions. The dominant current direction was northeastward. The highest mean surface intensity was registered during the 3,000 L.h ${ }^{-1}$ flow release (approximately $0.8 \mathrm{~m} \cdot \mathrm{s}^{-1}$ ) while, for the other layers, more intense currents were observed during the control data acquisition. With no gas release, the current was at least $0.1 \mathrm{~m} \cdot \mathrm{s}^{-1}$ different when compared to the data obtained during the gas releases and was predominantly directed northward.

For the neap tide data collection, the predominant current direction was northward, more specifically northeastward. The current intensities presented high mean surface values during the high flow release at the ebb tidal stage (approximately $0.5 \mathrm{~m} . \mathrm{s}^{-1}$ ). However, it was during the control data acquisition at high tide that the highest mean values were observed for the other two layers.

During high tide (Fig. 6b), the most frequent current direction was northwestward, except for the control data collection, which was directed northeastward. More intense currents were observed during the $9,000 \mathrm{~L}^{-\mathrm{h}^{-1}}$ gas release (up to $0.4 \mathrm{~m} \cdot \mathrm{s}^{-1}$ ) at the 
LEITE, F. S. et al. Field study of a simulated subsurface gas blowout in tropical and shallow water along the Brazilian Coast.

surface. However, it was during the control data acquisition that more intense currents were registered for the other two water column layers.

By the time of the neap ebb tide (Fig. 6c), the current directions were more frequently toward the northeast-north, except for the bottom layer pointing eastward during the high flow. The highest mean intensities were registered during the high flow release (up to $0.5 \mathrm{~m} \cdot \mathrm{s}^{-1}$ ), mainly for the surface and bottom layers. Without the gas release, currents directions prevailed to the north and the velocities were less intense than those observed during the gas releasing periods.

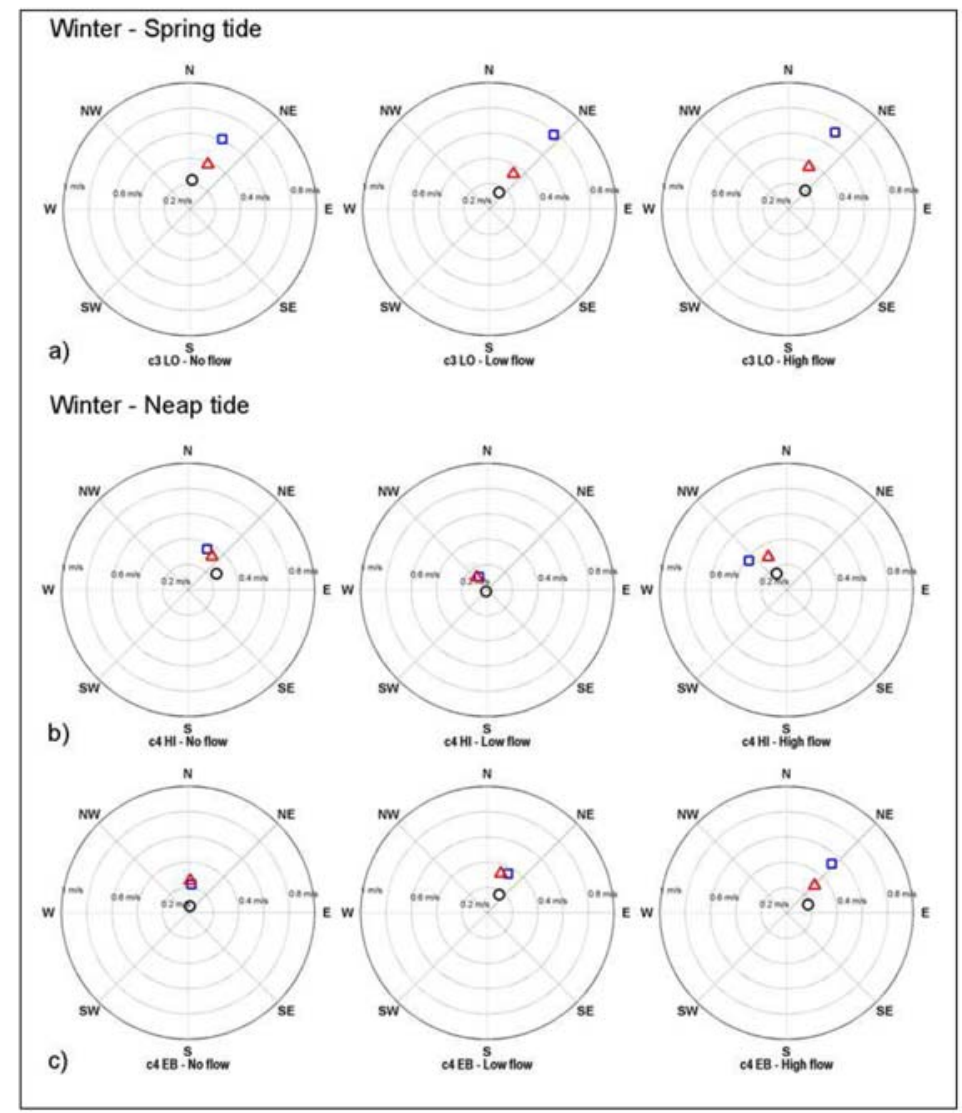

Figure 6 - Polar plots of the winter mean velocity current values for the surface ( $\square$ ), middle $(\triangle)$ and bottom $(O)$ of the water column during (a) the spring low tide, (b) the neap high tide and (c) the neap ebb tide.

The current direction prevailed toward the south-southwest during the summer period, when northeasterly trade winds are present (ARAUJO et al., 2011). Otherwise, during the winter period, the northeastward current preponderated as a consequence of the southeasterly trades, which are common during this season (SILVA et al., 2009). Weak wind shear effects associated with strong bottom variations in current direction were observed during dynamic tidal stages, when gravitational forces overrule the flow, as was observed by Araujo et al. (2005). 
LEITE, F. S. et al. Field study of a simulated subsurface gas blowout in tropical and shallow water along the Brazilian Coast.

The third campaign registered the highest current intensities (up to $0.8 \mathrm{~m} \cdot \mathrm{s}^{-1}$ at surface), which occurred in the spring low tide during the winter. This observation agrees with Araujo et al. (2005), who associated the stronger surface deviations in current intensity and direction to the slack water periods in Suape, when the wind shear stress is easily felt in the water column.

Current measurements were also registered by the S4ADWi current meter. A stick plot diagram, describing the current intensities and directions during the summer and winter campaigns, is presented in Figure 7. This figure also shows the comparison between the registered sea level variation and the variation forecasted by Suape Harbor (DHN, 2007, 2008).

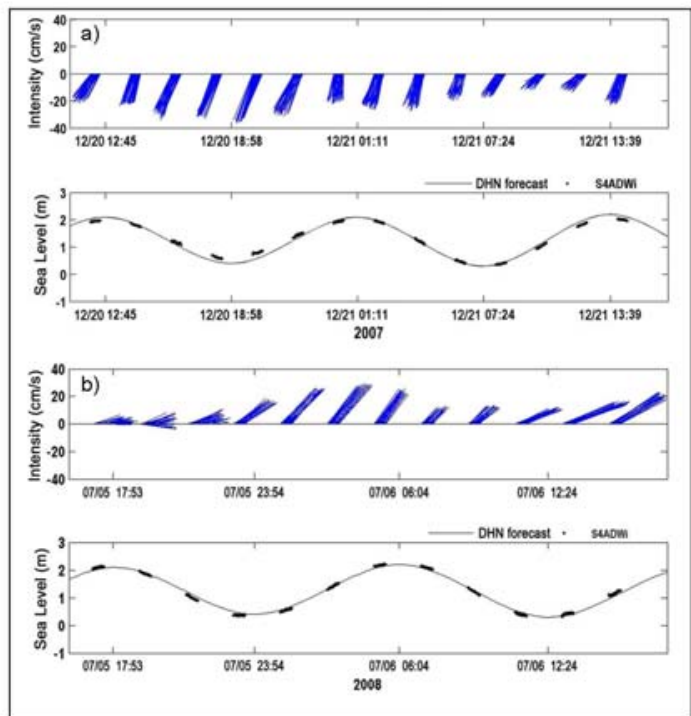

Figure 7 - Stick plot diagram of the current velocity vector and sea level variation registered at (a) the summer and (b) the winter period campaigns.

In the summer period, this equipment registered current intensities of up to 0.4 $\mathrm{m} . \mathrm{s}^{-1}$ and a predominant southwest-southward direction. The same intensity was also observed during the winter period; however, the current velocity mean value was higher during the winter and the northeastward current direction prevailed. The values that were obtained by the S4ADWi current meter were lower than those found by the ADCP. However, stronger currents were registered during the winter period by this profiler, as it was also detected by the S4ADWi current meter. Additionally, the directions of the currents were in complete agreement between both pieces of equipment, with the currents prevailing toward the southwest-south directions in the summer and northeastward in the winter period.

The incongruity in the current intensity results can be explained by the different dates that the S4ADWi current meter data were recorded (only $24 \mathrm{~h}$ for each period), when the tide, wind and other natural events (such as summer rains, droughts and extreme heat) are considered together. The agreement in current direction can be interpreted as the steady influence of the wind, which is more stable when considering the predominance during both periods.

Compared to the oscillations obtained by Suape Harbor (PE), the sea level variation in the study area during the dry and rainy periods was not significantly different from the 
LEITE, F. S. et al. Field study of a simulated subsurface gas blowout in tropical and shallow water along the Brazilian Coast.

calculated approximation given by DHN $(2007 ; 2008)$. Therefore, there was no important time lag between the measured values and those calculated at that harbor.

\section{Thermohaline Structure}

The thermodynamic data are presented in Figures 8 and 9, during the summer and winter periods, respectively. These data emphasize the physical differences between seasons, when salinity and temperature variations compromise the buoyancy and the rising velocity of the gas plume.

\section{Summer period}

The first field campaign, which occurred during the neap ebb tide with the release of 6,000 L. $^{-1}$ flow, presented values of seawater physical properties (Fig. 8a) ranging between 37.0 and 37.2 for salinity, $25.8{ }^{\circ} \mathrm{C}$ and $27.6^{\circ} \mathrm{C}$ for temperature and 1024.1 $\mathrm{kg} \cdot \mathrm{m}^{-3}$ and $1024.9 \mathrm{~kg} \cdot \mathrm{m}^{-3}$ for density. With the flow release of $9,000 \mathrm{~L} \cdot \mathrm{h}^{-1}$, the CTD values (Fig. 8b) varied from 36.9 to 37.2 for salinity, $25.8^{\circ} \mathrm{C}$ to $27.6^{\circ} \mathrm{C}$ for temperature and a density range identical to the lowest flow release. The control data presented nearly the same behavior as the data when the gas flows were released. The salinity and density increased with depth, while the temperature presented the opposite behavior. Below 18 meters deep, the change in these parameters was negligible.

During the second campaign, at the spring low tide, the vertical distribution of the salinity/ temperature/ density (Fig. 8c) presented, respectively, minimum values of 36.9/ $25.3{ }^{\circ} \mathrm{C} / 1024.1 \mathrm{~kg} \cdot \mathrm{m}^{-3}$ with a $3,000 \mathrm{~L}^{\mathrm{h}} \mathrm{h}^{-1}$ gas flow release. The maximum values for these parameters were, respectively, $37.2 / 27.4{ }^{\circ} \mathrm{C} / 1025.1 \mathrm{~kg} \cdot \mathrm{m}^{-3}$. At close to 20 meters deep the thermocline ended, where the values of the parameters did not present any abrupt difference with increasing depth. The control data obtained during this tide were similar to the low flow release as shown in Figure 8d. Registers of these parameters during the 9,000 L.h $\mathrm{h}^{-1}$ of natural gas release were the same as those for the low flow, except the maximum values of temperature and salinity, which presented only 0.1 unit of difference between the flows. At approximately 21 meters deep, which was the end of the thermocline, these values stabilized with depth.

At the spring flood tide, when a 3,000 L. $\mathrm{h}^{-1}$ gas flow was released, the vertical distribution of salinity, temperature and density (Fig. $8 \mathrm{e}$ ) presented, respectively, minimum values of $36.8 / 25.3^{\circ} \mathrm{C} / 1024.0 \mathrm{~kg} \cdot \mathrm{m}^{-3}$ and maximum values of $37.3 / 27.5^{\circ} \mathrm{C} /$ $1025.1 \mathrm{~kg} \cdot \mathrm{m}^{-3}$. During a 9,000 L.h ${ }^{-1}$ gas discharge (Fig. 8f), these parameters were identical to those from the low flow, except for the minimum salinity, which was only 0.1 higher. The base of these clines (for salinity, temperature and density) was close to a depth of 23 meters. These parameters became constant according to the increasing depth for both of the released flows. Similar to the first campaign, there was no explicit difference between these parameters for the different gas flow releases or the control data of this period. 
LEITE, F. S. et al. Field study of a simulated subsurface gas blowout in tropical and shallow water along the Brazilian Coast.

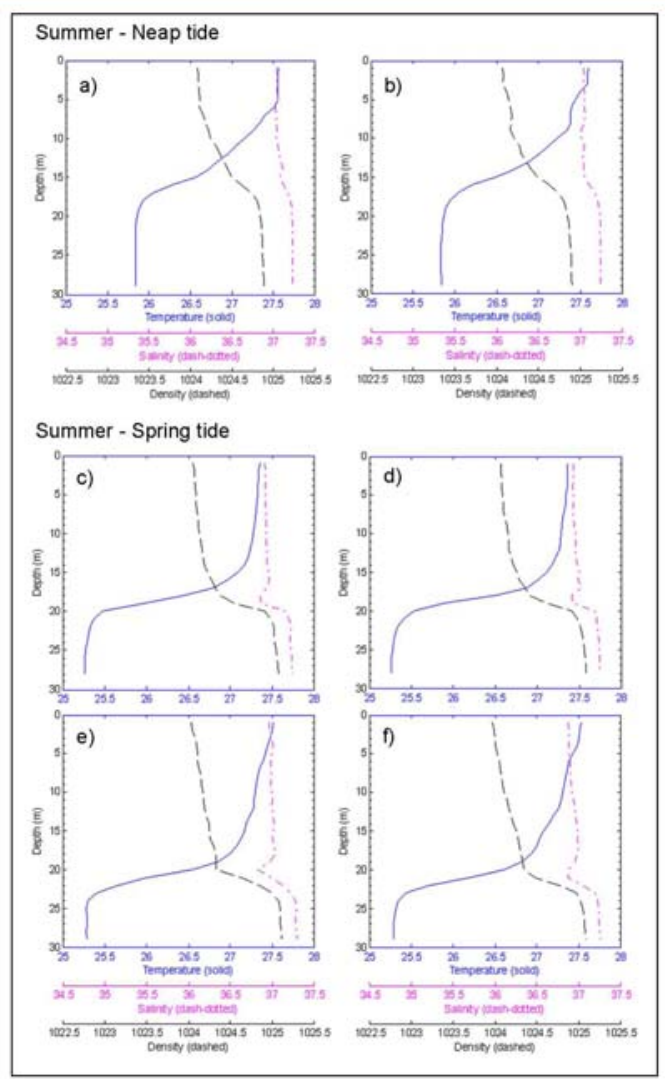

Figure 8 - Vertical CTD profiles during the summer period at neap ebb tide for flow releases of: (a) 6,000 L.h ${ }^{-1}$ and (b) 9,000 L.h. ${ }^{-1}$. At spring low tide, for flow releases of: (c) 3,000 L.h ${ }^{-1}$ and (d) no flow. At spring flood tide, for flow releases of: (e) 3,000 L.h. h $^{-1}$ and (f) 9,000 L.h.' .

\section{Winter period}

The third campaign corresponds to the spring low tide, when the thermodynamic data were not collected due to the sea condition during the first release of natural gas $\left(3,000 \mathrm{~L} . \mathrm{h}^{-1}\right)$. With the release of 9,000 L. $\mathrm{h}^{-1}$ of VNG, the salinity, temperature and density parameters (Fig. 9a) ranged between 34.7 and $37.0,26.0^{\circ} \mathrm{C}$ and $26.3^{\circ} \mathrm{C}$ and $1022.8 \mathrm{~kg} \cdot \mathrm{m}^{-3}$ and $1024.5 \mathrm{~kg} \cdot \mathrm{m}^{-3}$, respectively. As shown in Figure $9 \mathrm{~b}$, the data obtained without gas release presented values identical to the flow release. Initially, these parameters increased with depth in both situations, but they became essentially constant after approximately 6 meters, which was at the base of the clines.

The last campaign, which occurred during the neap tide, began with the release of 3,000 L.h. ${ }^{-1}$ of gas at the high tide (Fig. 9c) and showed a vertical distribution of salinity/ temperature/ density, respectively, from 36.7 to $37.0,26.2{ }^{\circ} \mathrm{C}$ to $26.3{ }^{\circ} \mathrm{C}$ and 1024.3 $\mathrm{kg} \cdot \mathrm{m}^{-3}$ to $1024.6 \mathrm{~kg} \cdot \mathrm{m}^{-3}$. Unlike the other scenarios, these values remained constant close to the surface. From approximately 9 meters and deeper, the salinity and density slightly increased with increasing depth, while the temperature values slowly decreased below this depth. The CTD values for the 9,000 L. $\mathrm{h}^{-1}$ flow release (Fig. 9d) comprised exactly the same ranges for salinity, temperature and density. Similar to the former flow 
LEITE, F. S. et al. Field study of a simulated subsurface gas blowout in tropical and shallow water along the Brazilian Coast.

release, these parameters were essentially constant near the surface, presenting lower values at approximately 8 meters deep. The salinity and density continued to increase toward the bottom, although the temperature became almost constant (with a slight decrease) starting from $14 \mathrm{~m}$ down to the bottom.

During the neap ebb tide, the vertical distribution of the seawater physical properties registered the same data range for the flow releases and control data (Fig. 9ef). The salinity values presented a range from 36.7 to 36.9 , while temperatures extended shortly from 26.2 to $26.4{ }^{\circ} \mathrm{C}$, and density presented limits from 1024.2 to $1024.5 \mathrm{~kg} \cdot \mathrm{m}^{-3}$. The standard behavior of these parameters remained the same with increasing depth. However, the vertical distribution for both of the situations was slightly different. For the gas releases, the salinity and density began to rise constantly below $16 \mathrm{~m}$, while such an increase occurred below $14 \mathrm{~m}$ in the no-gas release scenario. The temperature decreased below the cited depths.

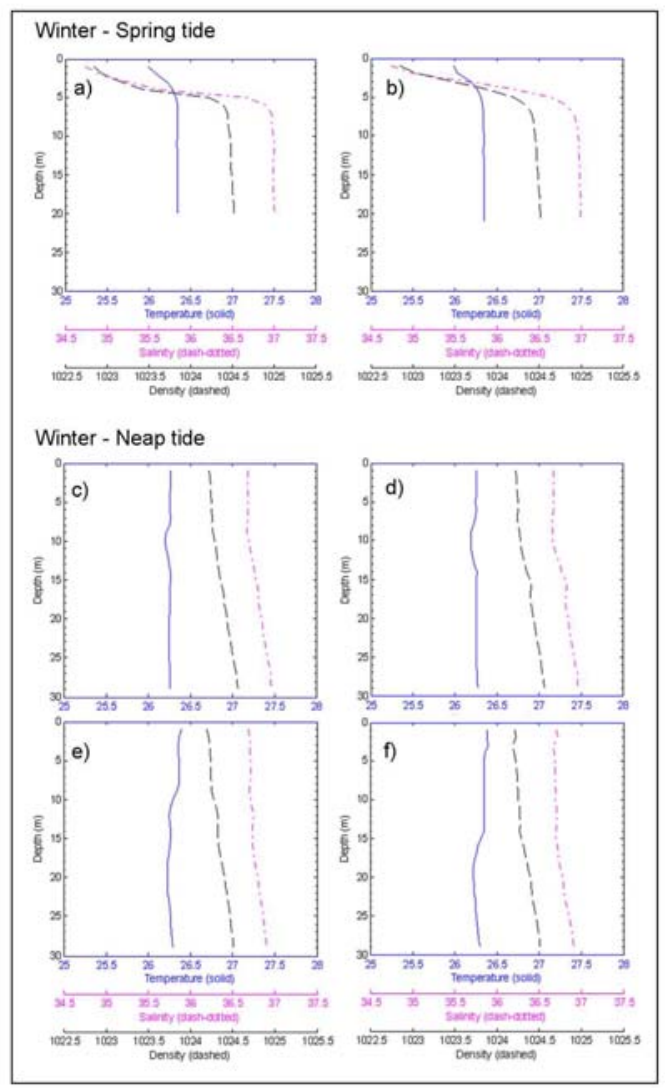

Figure 9 - Vertical CTD profiles during the winter period at spring low tide for flow releases of: (a) 9,000 L.h. -1 $^{-1}$ and (b) no flow. At neap high tide, for flow

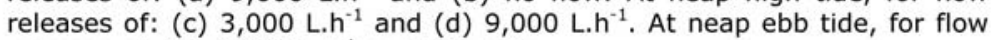
releases of: (e) 3,000 L. . ${ }^{-1}$ and (f) no flow.

The highest temperature, density and salinity values were recorded during the summer period, primarily during the neap ebb tide, likely because of evaporation that overcomes precipitation, resulting in shallow saltier waters (LINS, 2002). At this tidal 
LEITE, F. S. et al. Field study of a simulated subsurface gas blowout in tropical and shallow water along the Brazilian Coast.

condition, the vertical temperature profile reveals a mixed layer extending to 7 meters deep, as well as the base of the thermocline near the depth of $18 \mathrm{~m}$. Additionally, a pycnocline and a halocline-like structure were observed in an interval between 5-18 m. The maximum peak of temperature $\left(27.6^{\circ} \mathrm{C}\right)$ of all the four campaigns was registered during the high flow release of the neap ebb tide.

During the summer spring low tide, the lowest temperature of both periods was observed. Moreover, the gaps observed at the spring flood tide suggested the same approach reported by Rye et al. (1997). In experiments performed in stratified waters, McDougall (1978) and Asaeda and Imberger (1993) observed an undulating behavior of the plume in the vertical direction caused by stratification.

The greatest salinity and density differences along seawater depth (2.3 and 1.7 $\mathrm{kg} \cdot \mathrm{m}^{-3}$, respectively) were observed in the winter period, especially during the spring low tide. In general, the salinity and density data collected during this campaign contained the lowest values of all the campaigns. During this third campaign, there was a great inclination of the halocline and pycnocline from the surface down to 6 meters deep. The thermocline followed the same depth; however, temperature followed along a smoother variation, not exceeding $0.4^{\circ} \mathrm{C}$ of difference.

Areas with considerable variation within short depths are notable during the summer period due to the elevated values of temperature and salinity caused by solar radiation and evaporation, respectively, at the surface. As reported by Araujo et al. (2005), the water is homogeneous and well-mixed below this area, which is a common situation observed in coastal systems in the Northeast of Brazil (ARAUJO et al., 1999). In contrast, these variations along sea depth are not entirely clear in the winter season. This situation is likely caused by the intense southeasterly trade winds that are common during this period (ARAUJO et al., 2011) and can completely mix the shallow water column. However, a slight tendency toward increasing (decreasing) salinity and density (temperature) values occur with increasing depth.

\section{Subsurface Gas Releases and Recordings}

Johansen et al. (2003) suggested safety restrictions of surface vessel activities until all of the gas dissolves well beneath the surface in deep water blowouts. Blowouts in shallow waters are indeed dangerous once the gas reaches the surface, as has been observed during field campaigns, and can harm anyone who is on the surface using an engine.

The submarine recordings during all of the campaigns were performed outside the plume, which allowed for the observation of gas bubble clouds during the releases. It was possible to observe the displacement of the gas plume from the release point to the water surface. All of the observations and measurements of the plume width were recorded by the diver and confirmed in laboratory after screenshots and image analysis.

Examples of screenshots of the submarine recordings during summer and winter are presented in Figure 10. This set was chosen based on good screen visualization of the plume and the availability of simultaneous oceanographic data.

For the first campaign ( $\mathrm{C} 1$ ), during summer, screenshots were obtained for the 9,000 L. $h^{-1}$ flow release in the neap ebb tide. The width of the gas plume was one order of magnitude higher in the upper half of the water column than the lower half. Close to the bottom (approximately $24 \mathrm{~m}$ ), the plume diameter was approximately $0.3 \mathrm{~m}$, while near the surface (approximately $4 \mathrm{~m}$ deep), it was slightly higher than $2.0 \mathrm{~m}$. 
LEITE, F. S. et al. Field study of a simulated subsurface gas blowout in tropical and shallow water along the Brazilian Coast.

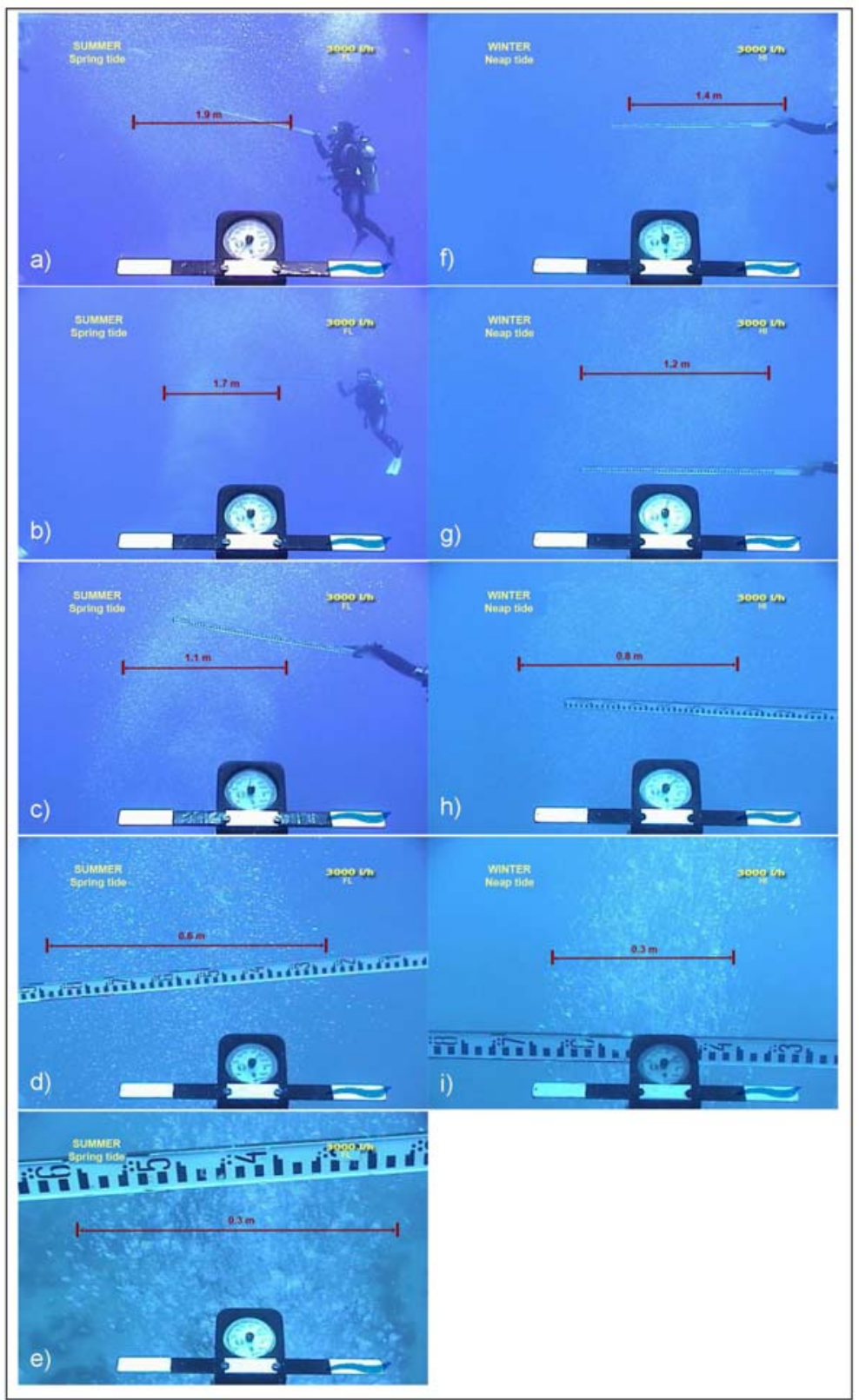

Figure 10 - Screenshots of the vertical evolution of the natural gas plume for the 3,000 L. $\mathrm{h}^{-1}$ flow release during the summer spring flood tide of C2 at depths of: (a) $2 \mathrm{~m}$, (b) $11 \mathrm{~m}$, (c) $15 \mathrm{~m}$, (d) $21 \mathrm{~m}$ and (e) $24 \mathrm{~m}$; for the 3,000 L.h ${ }^{-1}$ flow release during the winter neap high tide of $\mathrm{C} 4$ at depths of: (f) $13 \mathrm{~m}$, (g) $15 \mathrm{~m}$, (h) $21 \mathrm{~m}$ and (i) $24 \mathrm{~m}$ in the water column. 
LEITE, F. S. et al. Field study of a simulated subsurface gas blowout in tropical and shallow water along the Brazilian Coast.

In the second campaign (C2), which occurred during the summer spring tide, the plume breadth for the low gas release at low tide was approximately $0.3 \mathrm{~m}$ at $24 \mathrm{~m}$ deep and reached $1.2 \mathrm{~m}$ at the surface. For the $9,000 \mathrm{~L}^{-1} \mathrm{~h}^{-1}$ flow release, the gas plume presented a diameter between $0.3 \mathrm{~m}$ close to the bottom (approximately $24 \mathrm{~m}$ ) and 2.7 $\mathrm{m}$ close to the surface (approximately $4 \mathrm{~m}$ depth). The images obtained during the flood tide of the C2 campaign presented plume diameters ranging from $0.3 \mathrm{~m}$ for both flow

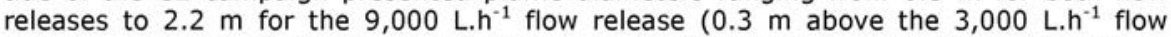
release - Fig. 10a-e). Despite the difference between the surface breadth of the low and high flow releases during the low tide, the order of magnitude of both tidal stages was the same for the $\mathrm{C} 1$ campaign.

The video recordings during the winter period presented muddy waters that brought difficulties in analyzing the gas plumes due to the poor visibility, mainly during the C3 spring tide. The visibility problem occurred because of a group of factors associated with moderate rainfall precipitation, strong surface wind stress, shallow depth, and estuarine output, such as levels of sediments, nutrient, pollutant and fresh water discharges into the ocean. For the neap tide, the last campaign (C4), the diameter of the plume was similar up to $15 \mathrm{~m}$ depth during both gas releases in the high tide. The diameter varied from $0.3 \mathrm{~m}$ close to the bottom to $1.2 \mathrm{~m}$ at the middle depth. However, the diameter near depths of $13 \mathrm{~m}$ was approximately $1.4 \mathrm{~m}$ during the low flow release (Fig. 10f-i), while it was approximately $1.3 \mathrm{~m}$ at $6 \mathrm{~m}$ from the surface for the $9,000 \mathrm{~L}^{-\mathrm{h}^{-1}}$ flow release. One can presume with these measurements that the plume diameter during the low flow release must be wider and closer to the surface. It was not possible to measure the plume diameter in the video recordings due to the camera approach. However, the video approach reaffirms the presumption of a bigger plume diameter.

According to the data, the gas plume displaced southward during the first campaign. During the second campaign, the plume presented a similar area at the surface during the highest gas flow release at both tidal stages. However, in contrast to campaign $\mathrm{C} 1$, the plume moved southwestward, which was closer to the coast, during the flood tide.

The width of the plume was similar from the bottom to the middle depth of the water column for all of the campaigns, which some images were able to capture. The difference appeared mainly at the surface, where the wind, wave, current and thermohaline structure may act all together to give a particular characteristic to the plume behavior. Observations from the vessel during the gas releases showed that the plumes took approximately 1.5 minutes to reach the sea surface. Yet, during all of the experiments, the gas rapidly dispersed upward when it reached the sea surface. The dispersion occurred due to the fact that natural gas is $35 \%$ lighter than air (RIVKIN, 2007; OBANIJESU and MACAULAY, 2009) and, in a shallow area, it passes throughout the water column.

During the summer period, the gas plume presented a width higher than $2 \mathrm{~m}$ close to the surface and a displacement southward at the first campaign, which is explained mainly by tidal forcing. The video images generally indicated southward current directions with mean surface intensities of $0.6 \mathrm{~m} . \mathrm{s}^{-1}$, which induced the plume transport towards this direction. The significant wave height presented lower values (from 0.7 to $1.0 \mathrm{~m}$ ) compared to the winter values, and the wave direction prevailed westward, with a significant period of approximately 6.6 seconds.

The tendency of the plume to displace southwestward during the summer spring tide was observed in both tidal stages. The surface plume width at this condition varied from $1.2 \mathrm{~m}$ to $2.7 \mathrm{~m}$ at the surface. This behavior represents a mix of meteorological and tidal forcing influences. As presented by the wind results and observed by other authors (LINS, 2002; ARAUJO et al., 2011), the winds vary between the east and northeast during the summer, despite the southeasterly predominance in this region. Moreover, currents moved toward the southern and western directions with mean current velocities varying between 0.4 and $0.7 \mathrm{~m}^{-1} \mathrm{~s}^{-1}$, which may influence the plume displacement. 
LEITE, F. S. et al. Field study of a simulated subsurface gas blowout in tropical and shallow water along the Brazilian Coast.

The winter period presented a mixed water column with stronger southeasterly trade winds, a higher significant wave height, which varied from 1.2 to $1.8 \mathrm{~m}\left(T_{\mathrm{s}} \sim 7.2\right.$ s), and a wave direction towards the northwest-north. Higher intensity currents moving northeastward were observed mainly during the spring tide campaign. According to the data collected, the gas plume likely moved toward the northeast-north direction.

During the winter neap tide it was possible to obtain screenshots of the plume evolution in the water column. The inclination of the plume displacement was northeastward, because the wind and wave conditions were prominent. In addition to these conditions, the current direction also predominated northeastward, and its intensities reached $0.5 \mathrm{~m} . \mathrm{s}^{-1}$, which contributed to the narrower plume width.

Table 2 presents a synthesis of the results with the main characteristics of the gas plumes observed during the sea campaigns.

Table 2 - Synthesis of the observed results of the gas plumes during the sea campaigns.

\begin{tabular}{c|c|c|c}
\hline Period & Tide & Plume Transport & Mean Plume Width at Surface $(\mathrm{m})$ \\
\hline \multirow{2}{*}{ Summer } & Neap & $\mathrm{S}$ & 2.0 \\
\cline { 2 - 4 } & Spring & SW & 2.7 \\
\hline \multirow{2}{*}{ Winter } & Neap & NE-N & 1.4 \\
\cline { 2 - 4 } & Spring & NE & 2.0 \\
\hline
\end{tabular}

CONCLUSION

As far as we know this study represents the first gas release experiment performed in shallow and tropical waters. Four distinct scenarios with different geophysical forcing were associated with two different gas release rates and seasonal periods. It was possible to collect a comprehensive and valuable data set to supply a baseline data for model calibration and validation in addition to documenting the methodology. The information allowed for the characterization of the plume evolution throughout the water column in distinct conditions of geophysical forcing associated with seasonal periods.

Results confirm that gas plume displacement was always influenced by the tidal and meteorological forcings. During the austral summer, the wind blew from the eastnortheast with mean intensity of $7.2 \mathrm{~m} . \mathrm{s}^{-1}$. Significant wave heights were registered around $0.9 \mathrm{~m}$ propagating mainly westward with significant period about $6.7 \mathrm{~s}$. Mean surface current intensities were around $0.5 \mathrm{~m} . \mathrm{s}^{-1}$ toward the south-southwest direction. Vertical stratification was clear at the water column with values of seawater physical variables almost constant below 20 meters deep. The gas plume displaced southsouthwestward and presented an observed plume width up to $2.7 \mathrm{~m}$ close to the surface. During the austral winter, the wind blew stronger from the southeast presenting mean intensity of $6.6 \mathrm{~m}^{-1} \mathrm{~s}^{-1}$. Significant wave heights around $1.6 \mathrm{~m}$ were registered propagating often northwestward with significant period about $7.2 \mathrm{~s}$. Mean surface current intensities were around $0.5 \mathrm{~m} \cdot \mathrm{s}^{-1}$ toward the northeast direction. A slight mixed water column was observed. The gas plume presented a width higher than $1.3 \mathrm{~m}$ close to the surface and a northeast-northward displacement.

Because of the paucity of studies in tropical shallow waters, available information in literature concerning methodological approaches and field data collection has focused primarily on temperate deep waters. As this is the first known gas experiment performed in the shallow coastal waters of Brazil, it seems also important to register difficulties and suggestions for later studies. For example, a considerable improvement for this methodology would be setting four rectangular GPS waypoints, with the gas release location and the potential area for plume dispersion inside it to acquire better data for comparison. This simple practical approach would avoid additional efforts to align and to compare measurements issued from different campaigns.

Another aspect is associated with the absence of a real-time strict recording control from the surface, which would lead to a better capture of the overall plume evolution. Additionally, the water turbidity during winter campaigns lowered the quality of the video 
LEITE, F. S. et al. Field study of a simulated subsurface gas blowout in tropical and shallow water along the Brazilian Coast.

recordings. Such mishaps could be amended with the use of a camcorder spotlight or, even better, with the use of a ROV. Finally, the ADCP results sometimes did not registered the data, which could be associated with the intersection of the transmitted pulse with the gas bubbles. As experienced by Johansen et al. (2003), the use of echo sounders was effective for tracking the gas bubbles as the bubbles raised through the water column. This observation points out a probable calibration problem for the ADCP use because it operated with a $600 \mathrm{kHz}$ transducer, while Johansen et al. (2003) tested transducers from 18 to $200 \mathrm{kHz}$, and the best results came from the $38 \mathrm{kHz}$ transducer. Several tests with the ADCP frequency should be taken into account. These experiments would help to calibrate the equipment and to obtain an accurate value to track gas bubbles. It has been fairly successful for former researchers in deeper waters in obtaining higher quality dimension measurements of the plume.

The earlier suggestions would lead to improve data quality for next in situ experiments. Nevertheless, results presented and discussed here represent an original and very useful dataset for calibration and validation of underwater gas blowout models in tropical and shallow oceanic systems.

\section{AKNOWLEDGEMENTS}

This research was financially supported by the Brazilian National Research Council (CNPq) under the project grants 550197/2005-2 (CTPetro 16/2005) and 558143/2009-1 (CTHidro/CTInfra 38/2009). The authors are thankful to everyone who was engaged in the field campaigns. The authors also thank Dr. Raul Montagne (UFRPE, Brazil) and Fabrice Hernandez (IRD, France) for providing valuable comments that improved the manuscript.

\section{REFERENCES}

ARAGÃO, J. O. R. A Influência dos Oceanos Pacífico e Atlântico na Dinâmica do Tempo e do Clima do Nordeste do Brasil. In: Eskinazi-Leça, E.; Neumann-Leitão, S.; Costa, M. F. (Orgs.). Oceanografia: Um cenário tropical. $1^{\text {a }}$ ed. Recife/PE: Edições Bagaço, 2004. p. 131-184.

ARAUJO, M.; LHERITIER, D.; SILVA, M. A.; LUNA, M. C.; MEDEIROS, C. Tidal turbulence and eddy-viscosity in coastal waters at northeastern Brazil. Journal of Coastal Research, v. 21, p. 18-27, 2005.

ARAUJO, M.; LIMONGI, C.; SERVAIN, J.; SILVA, M.; LeITE, F. S.; VELEDA, D.; LENTINI, C. A. D. Salinity-induced mixed and barrier layers in the Southwestern tropical Atlantic Ocean off the Northeast of Brazil. Ocean Science, v. 7, p. 63-73, 2011.

ARAUJO, M.; MEDEIROS, C.; RIBEIRO, C. Energy balance and time-scales of mixing and stratification in the Jaboatão estuary, NE-Brazil. Revista Brasileira de Oceanografia, V. 47, p. $145-154,1999$.

ASAEDA, T.; IMBERGER, J. Structure of bubble plumes in linearly stratified environments. Journal of Fluid Mechanics, v. 249, p. 35-57, 1993.

BEEGLE-KRAUSE, C. J.; LYNCH, W. Combining modeling with response in potential deep well blowout: lessons learned from thunder horse. Proceedings of the International Oil Spill Conference, Miami Beach, p. 1-6, 2005.

BOCK, E. J.; HARA, T.; FREW, N. M.; MCGILLIS, W. R. Relationship between air-sea gas transfer and short wind waves. Journal of Geophysical Research, v. 104, p. 2582125831, 1999.

BREWER, P. G.; ORR JR., F. M.; FRIEDERICH, G.; KVENVOLDEN, K. A.; ORANGE, D. L.; MCFARLANE, J.; KIRKWOOD, W. Deep-ocean field test of methane hydrate formation from a remotely operated vehicle. Geology, v. 25, p. 407-410, 1997.

BREWER, P. G.; ORR JR., F. M.; FRIEDERICH, G.; KVENVOLDEN, K. A.; ORANGE, D. L. Gas hydrate formation in the deep sea: in situ experiments with controlled release of methane, natural gas, and carbon dioxide. Energy \& Fuels, v. 12, p. 183-188, 1998. 
LEITE, F. S. et al. Field study of a simulated subsurface gas blowout in tropical and shallow water along the Brazilian Coast.

BULATOV, M. G.; KRAVTSOV, Yu. A.; RAEV, M. D.; REPINA, I. A.; SKVORTSOV, E. I. Microwave, optical and IR combined studies of the sea surface perturbations caused by underwater gas bubble plumes. IEEE Geoscience and Remote Sensing Symposium. IGARSS 2002, v. 5, p. 2983-2985, 2002.

CHEN, F. H.; YAPA, P. D. A model for simulating deepwater oil and gas blowouts - Part II: comparison of numerical simulations with "DeepSpill" field experiments. Journal of Hydraulic Research, v. 41, n. 4, p. 353-365, 2002.

DHN - Diretoria de Hidrografia e Navegação, 2007. Tábuas das marés. WWW Page, http://www.dhn.mar.mil.br (accessed 12.05.2007).

DHN - Diretoria de Hidrografia e Navegação, 2008. Tábuas das marés. WWW Page, http://www.dhn.mar.mil.br (accessed 06.30.2008).

FISCHER, D. W. Managing technological accidents: two blowouts in the North Sea. IIASA Proceedings Series, Pergamon Press, Oxford, 234 p., 1982.

JOHANSEN, $\varnothing$. DeepBlow - a Lagrangian plume model for deep water blowouts. Spill Science \& Technology Bulletin, v. 6, p. 103-111, 2000.

JOHANSEN, Ø.; RYE, H.; MELBYE, A.; JENSEN, H.; SERIGSTAD, B.; KNUTSEN, T. Deep Spill JIP Experimental Discharges of Gas and Oil at Helland Hansen, Parts I, II, and III - Technical Report, SINTEF Applied Chemistry, Norway, 2001.

JOHANSEN, $\emptyset$.; RYE, H.; COOPER, C. DeepSpill - Field study of a simulated oil and gas blowout in deep water. Spill Science \& Technology Bulletin, v. 8, p. 433-443, 2003.

LENEVEU, D. M. Analysis of potential acid gas leakage from wellbores in Alberta, Canada. International Journal of Greenhouse Gas Control, v. 5, n. 4, p. 862-879, 2011.

LINS, P. A. M. Hidrologia e hidrodinâmica do baixo estuário do Rio Ipojuca, PE. MSc Thesis, Department of Oceanography, Federal University of Pernambuco, Brazil, 2002.

MCDOUGALL, T. J. Bubble plumes in stratified environments. Journal of Fluid Mechanics, v. 85, p. 655-672, 1978.

OBANIJESU, E. O.; MACAULAY, S. R. A. West African Gas Pipeline (WAGP) project: associated problems and possible remedies. In: YANFUL, E. K. (Ed.). Appropriate Technology for Environmental Protection in the Developing World. Springer Books: Netherlands, 2009. p. 101-112.

PEEL, M. C.; FINLAYSON, B. L.; MCMAHON, T. A. Updated world map of the KöppenGeiger climate classification. Hydrology and Earth System Sciences, v. 11, p. 16331644, 2007.

RIVKIN, P. E. Hazards and hazard mitigation techniques for natural gas and hydrogen fueling operations. Process Safety Progress, v. 26, p. 27-34, 2007.

RYE, H.; BRANDVIK, P. J.; STROM, T. Subsurface blowouts: results from field experiments. Spill Science \& Technology Bulletin, v. 4, p. 239-256, 1997.

SILVA, M. A. Modelagem matemática da circulação e da dispersão de poluentes na região costeira do Porto de Suape - PE, Brasil. MSc Thesis, Department of Oceanography, Federal University of Pernambuco, Brazil, 2004.

SILVA, M. A.; ARAUJO, M.; SERVAIN, J.; PEVEN, P.; LENTINI, C. A. D. High-Resolution Regional Ocean Dynamics Simulation in the Southwestern Tropical Atlantic. Ocean Modelling, 30, 256-269, 2009.

WANNINKHOF, R.; ASHER, W. E.; HO, D. T.; SWEENEY, C. S.; MCGILLIS, W. R. Advances in quantifying air-sea gas exchange and environmental forcing. Annual Review of Marine Science, v. 1, p. 213-244, 2009. 
LEITE, F. S. et al. Field study of a simulated subsurface gas blowout in tropical and shallow water along the Brazilian Coast.

WUNSCH, C. What is the thermohaline circulation? Science. V. 298, p. 1179-1180, 2002.

YAPA, P. D.; DASANAYAKA, L. K.; BANDARA, U. C.; NAKATA, K. Modeling the impact of an accidental release of methane gas in deepwater. In: OCEANS 2008, 15-18 Sept. 2008, Quebec, CA. Conference publication, p. 1-10, 2008.

YAPA, P. D.; ZHENG, L.; NAKATA, K. Modeling Underwater Oil/Gas Jets and Plumes. Journal of Hydraulic Engeneering, v. 125, n. 5, 16872, 1999.

ZAPPA, C. J.; MCGILLIS, W. R.; RAYMOND, P. A.; EDSON, J. B.; HINTSA, E. J.; ZEMMELINK, H. J.; DACEY, J. W. H.; HO, D. T. Environmental turbulent mixing controls on air-water gas exchange in marine and aquatic systems. Geophysical Research Letters, v. 34, L10601, doi:10.1029/2006GL028790, 2007.

ZHENG, L.; YAPA, P. D.; CHEN, F. H. A model for simulating deepwater oil and gas blowouts - Part I: theory and model formulation. Journal of Hydraulic Research, $v$. 41, n. 4, p. 339-351, 2002. 


\section{Chapter 4}

\section{Modeling Subsurface Gas Release}

\subsection{SUMMARY OF THE RESULTS}

The data obtained in situ during four field campaigns were used in the analysis of the gas plume dispersion accounting for more than 10 different scenarios. The model formulations are presented as well as its use to simulate and compare the results with the small-scale field experiments conducted along the Northeast Brazilian coast. Theoretical propositions were obtained from Yapa and Zheng (1997) and usual framework and notations were adopted from Friedl and Fanneløp (2000).

The model is based on the linear momentum balance of gas, seawater and oil. The discretization of equations uses a Lagrangian control volume approach. The vertical displacement of this Lagrangian control volume calculates the plume evolution along the ocean depth for each numerical time step. The variation of mass inside the plume is provided considering the prime physical-chemical processes of water entrainment, gas dissolution and bubble separation.

The numerical results indicated an important gas plume displacement in the southwest-northeast axis with a southwest direction 
for the summer scenarios. The gas plumes were completely displaced from the release source along the southwest-northeast axis northeastward during the winter period scenarios. The plume displacement occurred inside a radius of $35 \mathrm{~m}$ from the gas release source, which was observed during the winter neap ebb tide toward the northeast. Comparing the experimental and numerical results, the model responded positively in reproducing the plume evolution throughout the water column presenting satisfactorily displacement, diameter and ascending time of the plume.

The next Section of this chapter presents the manuscript entitled Modeling Subsurface Gas Release in Tropical and Shallow Waters: Comparison with Field Experiments off Brazil's Northeast Coast accepted for publication in the Human and Ecological Risk Assessment: An International Journal and available on Taylor \& Francis Online at: http://www.tandfonline.com/doi/abs/10.1080/10807039.2012.723182 since August 30th, 2012. 


\subsection{PAPER}

\section{Modeling Subsurface Gas Release in Tropical and Shallow Waters: Comparison with Field Experiments off Brazil's Northeast Coast}

Fabiana S. Leite, Marcus A. Silva, Moacyr Araujo, Rodolfo A. Silva, and Enrique L. Droguett

Laboratory of Physical and Coastal Oceanography at the Oceanography Department and Center for Risk Analysis and Environmental Modeling, Federal University of Pernambuco, Cidade Universitária, Recife - PE, Brazil

Address Correspondence to Fabiana S. Leite, Laboratory of Physical and Coastal Oceanography at the Oceanography Department (LOFEC/DOCEAN) and Center for Risk Analysis and Environmental Modeling (CEERMA), Federal University of Pernambuco. Av. Arquitetura, s/n, Cidade Universitária, 50740-550, Recife - PE, Brazil, phone./fax: 55 81 2126-8227; E-mail: fasoares1@yahoo.ca

Running Head: Modeling Subsurface Gas Release 


\section{ABSTRACT}

Despite the fast grow of underwater oil and gas exploration in low latitude regions, very few experimental data acquisition and modeling involving gas release in tropical and shallow waters are found in literature. In this paper, a dataset of geophysical and gas release measurements obtained from an in situ experiment conducted off the Northeast Brazil coast are used as a baseline for evaluating the GASOCEAN blowout model. Hydrological and hydrodynamic data were collected for distinct seafloor gas plume releases $(3000$ to $9000 \mathrm{~L} / \mathrm{hr}$ ) during neap/spring tides of summer/dry and winter/rainy periods. Simulation results indicate that the gas plume is horizontally displaced by the horizontal current as it rises through seawater column. The extreme situation provided a critical radius (maximum horizontal displacement) from the gas release source of $35.2 \mathrm{~m}$. The comparison between the measured and the calculated data showed that the model satisfactorily represented the main features of the gas release, such as the displacement $(11.6-35.2 \mathrm{~m})$, diameter $(1.2-2.8 \mathrm{~m})$ and ascending time (1.1-1.6 $\mathrm{min})$ of the plumes. Although the mean plume widths have the same order of magnitude between the measurements and the calculations, improvements may enhance the model's performance during the earlier plume development.

Key Words: underwater gas blowout, tropical shallow water, northeastern Brazilian coast, mathematical modeling, GASOCEAN model. 


\section{INTRODUCTION}

Recent industrial accidents such as toxic spills have caused catastrophic damage to the ecological environment (plants and animals) and consequently great economic losses to the responsible company, as British Petroleum painfully learned after the oil spill in the Gulf of Mexico, causing one of the most severe ecological disasters in history and a loss to the company estimated at U\$37 billion to be spent with cleanup, fines, and repairs. However, this leakage could have been avoided with the purchase of an equipment of U\$500,000, able to seal the well in case of accident. The savings were therefore miscalculated under the risk-taking, which means that risk assessment estimates were inaccurate (Betti and Barrucho 2010).

Several other dramatic industrial accidents have occurred in recent years, resulting in the discharge of chemicals and damaging valuable ecosystems, e.g., the wrecks of the oil tankers Erika (1999) and Prestige (2002) and the chemical spills at Doñana (Spain) in 1998 and Baia Mare (Romania) in 2000. Furthermore, a high number of less harmful incidents happen every year (EEA 2003).

Despite the abovementioned events, oil and gas exploration from the sea floor has been experiencing a rapid growth in the low latitude regions. However, very few gas blowout experiments in tropical and shallow waters have been published by the scientific community. There are many differences between deep and shallow water blowouts (Zheng et al. 2002). In deep water blowouts the gas hydrate formation and decomposition occur due to the high pressure and low temperature, as well as gas dissolution when the depth is great. For blowouts at shallow to moderate depths, the gas dissolution from rising bubbles into seawater may be negligible and no hydrates are observed (Johansen 2000). In situ natural gas releasing experiments are expensive, dangerous, and demand logistical planning because they require the movement of people, equipment, and vessels. As a consequence, very few in situ experiments have been reported in literature, and most of them have occurred in high 
latitude/deep water situations (Brewer et al. 1997; Rye et al. 1997; Johansen et al. 2003). Brewer et al. (1997, 1998), for example, investigated the process of methane hydrate formation in experiments conducted during January 1996 at the depth of $910 \mathrm{~m}$ in Monterey Bay, USA. Rye et al. (1997) performed an experiment with air and oil subsurface release at $106 \mathrm{~m}$ during June 1996 in the North Sea. The experiment performed by Bulatov et al. (2002) was based on gas plume detection by microwave remote sensing methods without attention to the physical conditions of the plume. The experiment was executed during 2000/2001 using compressed air in the Black Sea. The DeepSpill set of experiments were also carried out by Johansen et al. $(2001,2003)$ during June 2000 at a depth of $844 \mathrm{~m}$ in the Norwegian Sea. The main goals of these experiments were to obtain high-quality data from a deep water oil/gas release and to use them to calibrate deep water plume models (Chen and Yapa 2002).

Concerning gas release modeling, initial efforts to study the evolution of a single gas plume in the ocean were conducted by Fanneløp and Sjøen (1980). Those authors proposed a simplified analytical model for spills in shallow waters with nondimensional solutions, neglecting the horizontal advection of the gas by the currents. Yapa and Zheng (1997) first considered the advective transport of the gas and the environmental thermodynamic conditions in equations to predict the space-time evolution of plumes. Later, Friedl and Fanneløp (2000) improved the model by adding routines for the fountain effect, when the sea surface is elevated by the gas reaching the surface. Other important processes were progressively improved in deep water modeling, such as bubble separation process (Davidson and Pun 1999; Davidson and Wang 2002; Socolofsky and Adams 2002), gas dissolution (Zheng and Yapa 2002; Johansen 2003), and gas hydration (Topham 1984a,b; Brewer et al. 1998; Chen and Yapa 2001; Yapa et al. 2008b).

A comparison between field and a model's results may therefore reveal where the largest potential for the improvement of existing models 
is expected. Rye et al. (1997) carried out in situ experiments with air, water, and oil subsurface releases at approximately $100 \mathrm{~m}$ depth during June 1996 in the North Sea. They used the SINTEF blowout model, which is a combination of two other subsurface release models published by Koh and Fan (1970) and Fanneløp and Sjøen (1980). Both models are based on the principle of the conservation of mass, momentum, and buoyancy to simulate the mixing of a subsurface jet. The authors found that the field methodology was appropriate. A number of features obtained from the field measurements were well reproduced by the model, such as the subsurface plume dimensions and the rising time of the plume. However, other features were not properly represented, such as the diameter, which was smaller than that measured, and the vertical velocity, which was higher than the measured, of the subsurface plume. Yapa and Zheng (1997) developed a three-dimensional numerical model based on the Lagrangian method to simulate the behavior of an oil and gas plume during a blowout. It considered shear-induced and forced entrainments in addition to stratified and unstratified ocean environments and multidirectional ambient currents. Zheng and Yapa (1998) used experimental data that comprised buoyant jets in unstratified and stratified environments. These data included cases both with and without ambient currents, as well as two- and tri-dimensional jet trajectories. The observed data were collected on small and large scales and compared with the numerical model's results, presenting satisfactorily comparable results. Zheng et al. (2002) developed a mathematical model called CDOG to simulate the behavior of oil and gas plumes released from deep water. The model integrates a set of modules regarding jet/plume hydrodynamics and thermodynamics, the kinetics and thermodynamics of hydrate formation, and decomposition and gas dissolution. The numerical results obtained by CDOG were compared with the "DeepSpill" field data (Johansen et al. 2001, 2003) by Chen and Yapa (2002) and presented satisfactory results despite some constrains related to the experiments like the uncertainty regarding hydrate formation. In addition, the authors concluded that gas 
releases from these depths (approximately $800 \mathrm{~m}$ ) will be entirely dissolved before they can reach the surface.

The experiments performed by Rye et al. (1997) were simulated by Yapa and Xie (2002) using the COMBOS3D model (Yapa et al. 1999) with the purpose of testing the model's ability to predict underwater blowouts. The same set of coefficients was used for all the simulations and the entrainment formula was described by Yapa et al. (1999). The numerical and experimental comparison was reasonably good for distances far from the nozzle, and better results were obtained for jets with a higher GLR (gas to liquid ratio), which was from $67 \mathrm{~N} \mathrm{~m}^{3} \mathrm{~s}^{-1} / \mathrm{m}^{3} \mathrm{~s}^{-1}$ and greater. The differences observed were due to experimental errors and the inadequate entrainment provided by the entrainment formula for the lower GLR. The authors concluded that the model is capable of simulating oil and gas spills only if no hydrates are formed.

A coherent dataset collected in deep water able to calibrate plume models was generated by the DeepSpill experiments (Johansen et al. 2003). Johansen (2000) compared this experimental dataset with the numerical results of the DeepBlow model. The model included cross currents, gas dissolution, hydrate formation, gas bubbles escape from a bent plume, and underwater plume trapping. The numerical results predicted hydrate formation, but no hydrate was observed. According to the model, natural gas dissolved more quickly when compared to the field data. After some adjustments, the model satisfactorily predicted the surfacing time of the plume and the location of the slick. In another publication, Johansen (2003) reviewed the theories and behaviors of deep water blowouts and compared them to those for shallow water. The author observed that the slick formation in deep water releases will be governed by the surfacing of individual oil droplets in a depth and time variable current. In contrast, for shallow and moderate waters, the bubble plume will rise to the surface, forming a strong radial flow and, consequently, contributing to a rapid spreading of the oil in the surface. 
Yapa et al. (2008a) developed the MEGADEEP model to simulate the transport of methane gases from deep water. The foci of this model were gas and hydrates, and the model includes gas hydrate formation and dissociation, gas and hydrate dissolution, hydrate crumbling and reformation, and gas bubble size variety and splitting. As part of their analysis, the authors simulated the DeepSpill experiments and compared the numerical results with the DeepSpill field data. The simulations worked well, except for the simulation that formed hydrates because this was not observed during the experiments. This discrepancy was attributed to experimental uncertainties.

As far as the authors of this article are concerned there are very few studies addressing the analysis of gas plume evolution in coastal and tropical shallow waters. Neither the acquisition of experimental data nor its comparison to a model's results was found in the literature. The main objective of this paper is therefore to increase the knowledge concerning the gas behavior during a subsurface blowout under typical tropical and shallow seawater forcings.

The paper is structured as follows: a description of the experimental set-up and main model features are provided in the Methods and Materials section; measurements obtained during the experiments as well as the comparison between in situ observations and the model's simulations are described in the Results section. Finally, the Discussion section describes the comparison between field and numerical data as well as the conclusions from the study. The set of main equations and processes included in the model are presented in Appendix A. The symbols used in the paper are listed in Appendix B.

\section{METHODS AND MATERIALS}

\section{Gas Release Experiments and Sea State Measurements}

The sea experiments were conducted in the coastal region near the Suape Harbor industrial park area, Pernambuco, Brazil. It comprised in situ observation of a natural gas plume throughout the water column. In this 
region, the climate is warm and humid (type Am - Peel et al. 2007) and two well-defined seasons are observed: the summer/dry season (from September to March) and the winter/rainy season (from April to August). The average annual rainfall is $1,500 \mathrm{~mm}$ and the evaporation is 1,200 $\mathrm{mm}$. Semidiurnal tides occur at Suape with a mean spring (neap) range of $2.2 \mathrm{~m} \mathrm{(1.1} \mathrm{m)} \mathrm{(Araujo} \mathrm{et} \mathrm{al.} \mathrm{2005).}$

The experiments were organized as 2-day campaigns with natural gas released from the sea bottom at approximately 30 meters depth, $11 \mathrm{~km}$ from the coastline (at $-8.40^{\circ}$ and $-34.85^{\circ}$; Figure 1), simulating a subsurface gas blowout. Four distinct campaigns with varied conditions of geophysical forcing were associated with different fluxes (from 3000 to $9000 \mathrm{~L} / \mathrm{hr}$ ), tides (spring and neap) and seasonal periods (summer and winter). Specifically, the campaigns $(\mathrm{C} 1, \mathrm{C} 2, \mathrm{C} 3, \mathrm{C} 4$; Table 1) occurred in order to: (i) characterize the evolution of hydrocarbon plumes in the water column during distinct seasonal and dynamic situations; and (ii) determine the existent hydrodynamic forcing during the dry and rainy seasons for the neap and spring tides.

Table 1. Summary of the sea campaigns.

\begin{tabular}{cccc}
\hline Period & Campaign & Tidal forcing & Date \\
\hline \multirow{2}{*}{ Summer } & C1 & Neap & $12 / 17-18 / 2007$ \\
& C2 & Spring & $12 / 23-24 / 2007$ \\
\hline \multirow{2}{*}{ Winter } & C3 & Spring & $07 / 05-06 / 2008$ \\
& C4 & Neap & $07 / 10-11 / 2008$ \\
\hline
\end{tabular}




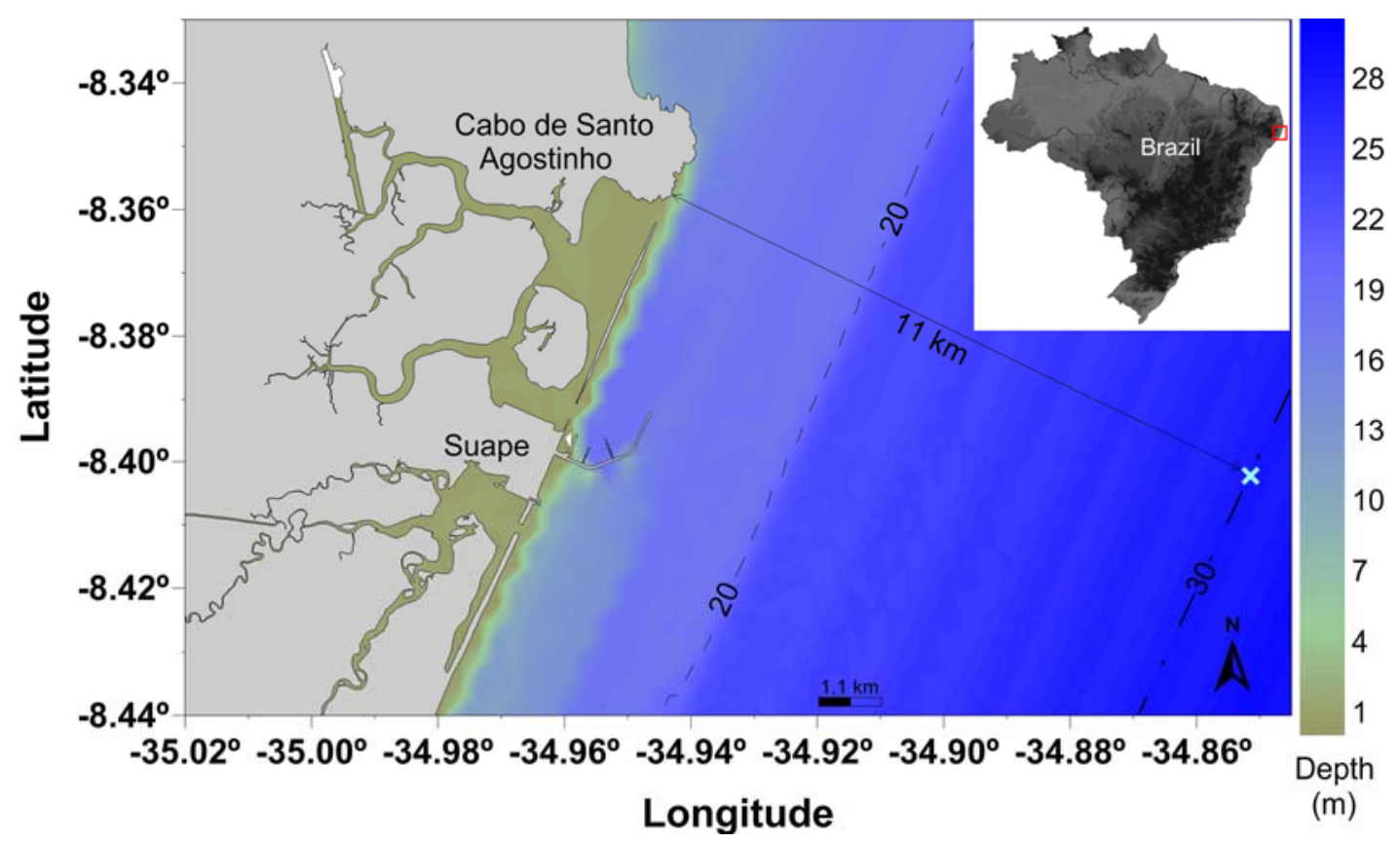

Figure 1. Localization map in the coastal region of the Suape Harbor, Pernambuco, Brazil ( $\square$ ), presenting the experimental station ( $\times$ ), located $11 \mathrm{~km}$ far from the coastline (solid line). Isobaths of $20 \mathrm{~m}$ (dashed line) and $30 \mathrm{~m}$ (dashdotted line) are also plotted.

The months of December (2007) and July (2008) were chosen to represent the primary seasons of the region, which are the summer/dry and winter/rainy periods (Aragao 2004). Experiments were executed during neap and spring tides for each representative seasonal period. The sea work was completed during tidal stages that characterized the extremes of the dynamic situation - slack water tidal period (high or low tidal stage) and dynamic tidal period (flood or ebb tidal stage). In Figure 2 are exhibited the main activities during the subsurface blowout field experiment. 


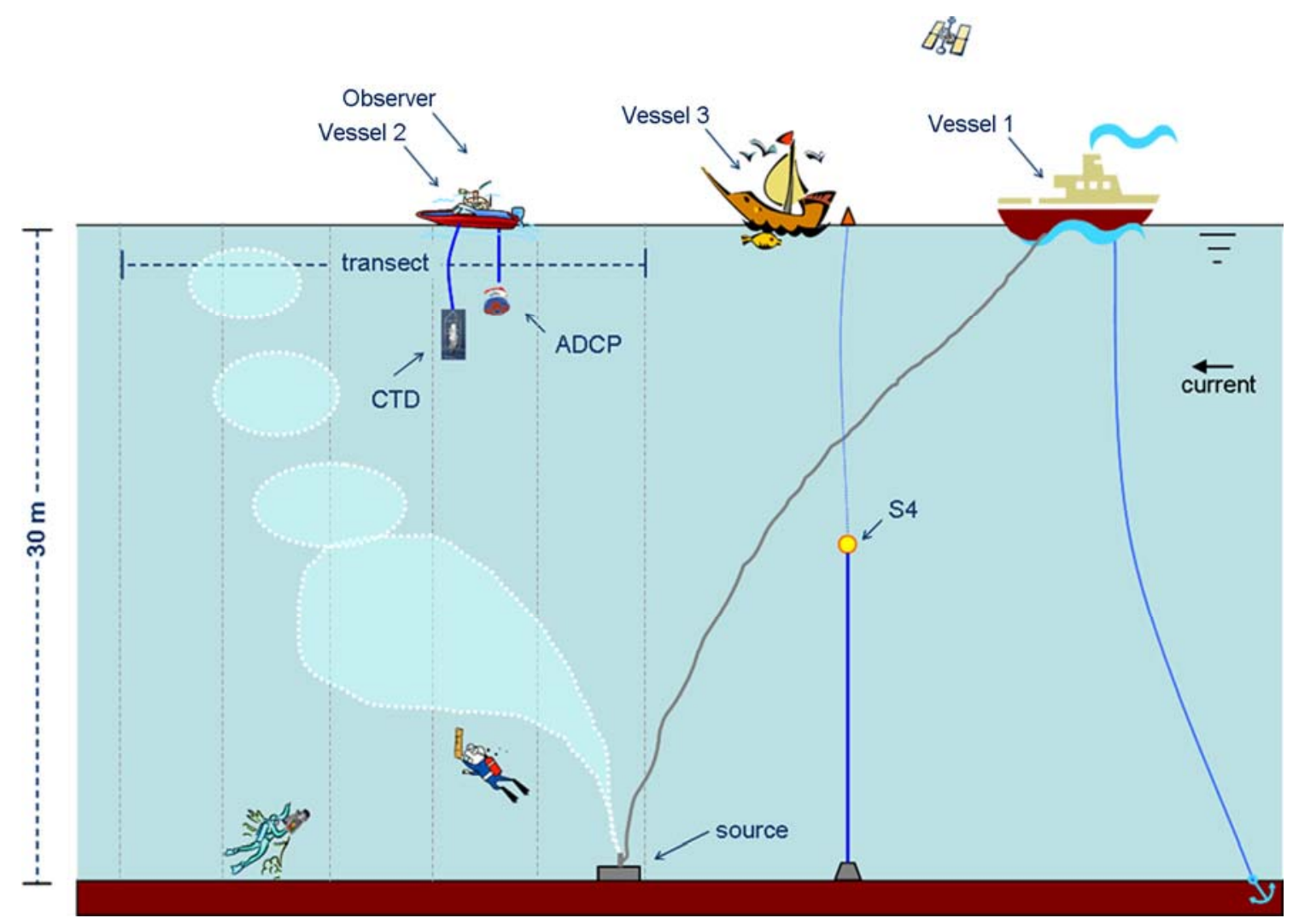

Figure 2. Logistic scheme of the field campaigns.

The composition of Vehicular Natural Gas (VNG) is similar to that of methane, which in turn is the predominant gas from exploitation reservoirs. Because of that, the release arrangement used three $7.5 \mathrm{~m}^{3}$ VNG cylinders (Figure 3), also taking into account the VNG facility to acquire and manipulate. A panel-like device, especially made for the gas release, consisted of two manometers and one rotameter with two simultaneous gas outlets. The outlet arrangement consisted of a U-shaped release pipe, which was anchored to a 20-kg ballast, guiding the release almost vertically upwards. The diameter of the nozzle was $1 / 4$ inches, which was hooked to the ballast at $30 \mathrm{~m}$ depth. During the campaigns, the fluxes were released (exit conditions) through a 1/4-inch flexible hose at 3000 and $9000 \mathrm{~L} / \mathrm{hr}$ (low and high flows, respectively), except for C1 campaign, for which the low flow was set to $6000 \mathrm{~L} / \mathrm{hr}$. 


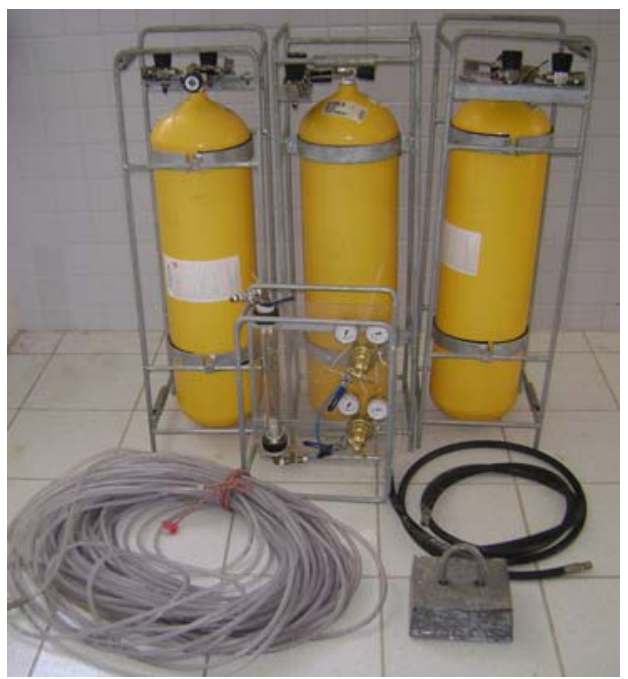

Figure 3. Set of used equipment for gas release from the sea bottom.

The gas release from the bottom to the sea surface was recorded by a diver with a digital video camera (mod. Sony TRV130) in a waterproof case (mod. Croma-MR1). The camera had an "arm" attached in front of it with a depth gauge in its extremity. A second diver held a 1.4 meter ruler as a reference of size to later calculate the gas bubble plume's dimension. To obtain relevant plume data, natural gas was released over a time span of approximately 15 minutes for each flow rate.

Sea measurements were simultaneously performed to collect background information with S4, ADCP, and CTD equipment, as well as video recordings of underwater plume evolution. The wave field characterization and the tide gauge measurements were obtained with the Interocean S4ADW-i Current Meter. This equipment was moored for 24 hours at half the mean depth water. Data were registered at a $2 \mathrm{~Hz}$ sampling rate every three (two) hours in the summer (winter) period during periods of 30 minutes. The tide gauge data at this frequency allowed for the characterization of the temporal evolution of the highfrequency (wind-driven waves) and low-frequency (tide-driven waves) waves that occurred in the area during the campaigns. The ADCP equipment (mod. Workhorse Rio Grande $600 \mathrm{kHz}$ ), configured for 80 levels, was placed half a meter from the water surface to collect current intensity and direction. Thermodynamic data were obtained by the CTD 
equipment (mod. SBE-19plus Seacat Profiler) performing one vertical profile in the plume of rising droplets during each gas flow release.

\section{GASOCEAN Model Formulation}

A mathematical model was used for the forecasting and analysis of a gas plume evolution throughout the water column. The model's development was primarily based on theoretical propositions from Yapa and Zheng (1997) and (Chen and Yapa 2004). Following the usual framework and notations used in previous gas modeling, the nomenclature proposed by Friedl and Fanneløp (2000) was adopted. A summary of the equations used for the model's development is presented in Appendix A.

The model GASOCEAN is founded on the linear momentum balance of gas, seawater, and oil. The variation of mass inside the plume is provided considering the prime physical-chemical processes of water entrainment, gas dissolution, and bubble separation process.

The bubble slip velocity $\left(\mathrm{w}_{\mathrm{b}}\right)$ is intimately related to the sea temperature and its practically stable condition of relative density with the surroundings. According to some authors (Yapa et al. 1999, Yapa and Zheng 1997, Zheng and Yapa 2000), the vertical velocity difference between the gas and liquid inside a plume $\left(\mathrm{w}_{\mathrm{b}}\right)$ varies from 0.25 to 0.35 $\mathrm{m} / \mathrm{s}$. A gas bubble, which ranges in diameter from 1 to $10 \mathrm{~mm}$, affects the plume behavior as the slip velocity of gas bubbles (Zheng et al. 2002). In this study, the slip velocity for underwater releases was assumed to be 0.3 $\mathrm{m} / \mathrm{s}$ as proposed by Yapa and Zheng (1997) and Johansen (2000).

The fate of the underwater plume is also determined by the entrainment process. As the plume rises through the water column, the ambient fluid enters through the outer surface of the plume. There are many models that use methods of constant coefficient, which need to change the coefficient based on the case under consideration. In this paper we use the equations given in Yapa and Zheng (1997), which extended the formulations proposed by Lee and Cheung (1990) to account 
for 3D velocities. These equations do not require changing entrainment coefficients from case to case.

Another implementation of the GASOCEAN model regards the gas dissolution mechanism in the plume's surroundings and the bubble separation process during the plume's ascension (Johansen 2003; Zheng and Yapa 2002). Based on Henry's Law, the concentration gradient across the bubble interface causes its dissolution. Accordingly, if the aqueous methane concentration of the plume enhances, the gradient decreases and slows the bubble's dissolution (Leifer et al. 2006).

The gas slip velocity makes gas rise faster than the plume fluid. The whole trajectory of the bubbles may vary expressively because of this gas separation. The critical length represents the distance at which occurs the separation between the plumes of gas and oil. Its computation is done by comparing the momentum in the control-volume (gas and oil) with the horizontal momentum induced by environmental current fields.

In the present simulations, the considered main component of the gaseous mixture was methane $\left(\mathrm{C}_{1}\right)$, which totals $94.2 \%$ of the VNG released. The ambient salinity, temperature, density, and current velocity fields at each depth, obtained during the campaigns in the coastal region of the Suape Harbor industrial park area, were used to represent sea conditions in the gas plume model. Those forcings were used as the input data to the GASOCEAN model to simulate the evolution of the gas plume. The model's main parameters used in the simulations are listed in Table 2.

Table 2. Model input data/parameters used in simulations.

\begin{tabular}{ll}
\hline Parameter & Value \\
\hline Gas core width/jet diameter & 0.8 \\
Shear-induced entrainment coefficient & 0.083 \\
Orifice diameter & $0.00635 \mathrm{~m}$ \\
Bubble slip velocity & $0.3 \mathrm{~m} \cdot \mathrm{s}^{-1}$ \\
Initial bubble radius & $0.005 \mathrm{~m}$ \\
Molecular weight of gas & $0.017 \mathrm{~kg} \cdot \mathrm{mol}^{-1}$ \\
\hline
\end{tabular}




\section{RESULTS}

\section{Sea State Measurements and Gas Plume Evolution}

Wind measurements were obtained from the Porto de Galinhas meteorological station at $10 \mathrm{~m}$ height, which is located $15 \mathrm{~km}$ south of the study area. They presented mean intensity around $7 \mathrm{~m} / \mathrm{s}$ in both seasons with directions from east-northeast and from southeast during the austral summer and winter, respectively. Significant wave heights were registered between 0.7 to $1.0 \mathrm{~m}$, propagating mainly westward, and waves presented significant period of 6.5 to 6.7 seconds during the summer period. The winter period presented waves with significant heights between 1.2 and $1.8 \mathrm{~m}$ and significant period of 7.0 to 7.4 seconds, moving toward northwest.

Mean surface current intensities obtained with the ADCP were around $0.5 \mathrm{~m} / \mathrm{s}$ during both seasons. The current direction prevailed toward the south-southwest during the summer period. Otherwise, the northeastward current preponderated during the winter period as a consequence of the southeasterly trades (Figure 4). During the dry period, when highest salinity, temperature, and density values were recorded, thermodynamic data varied from 36.8 to $37.3 \mathrm{psu}$ for salinity, 25.3 to $27.6^{\circ} \mathrm{C}$ for temperature and 1024 to $1025 \mathrm{~kg} / \mathrm{m}^{3}$ for density. During the rainy period, these values ranged from 34.7 to 37 psu for salinity, 26 to $26.4^{\circ} \mathrm{C}$ for temperature, and 1022.8 to $1024.6 \mathrm{~kg} / \mathrm{m}^{3}$ for density. A vertical stratification could be observed during the summer season, differently from the winter, which registered a slight mixed water column (Figure 5). 

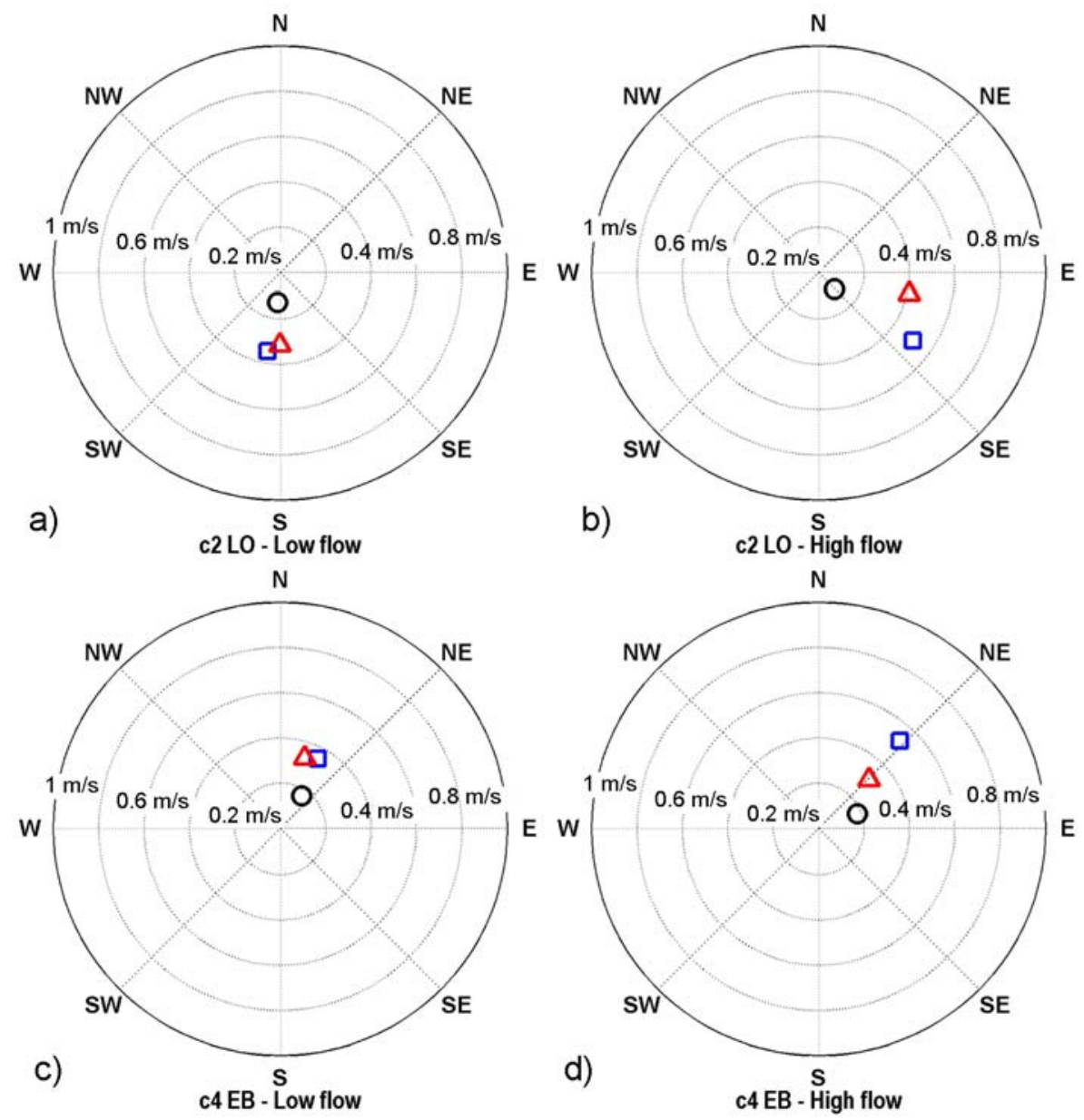

Figure 4. Polar plots of the mean current velocity for the surface ( $\square)$, middle $(\triangle)$ and bottom $(\mathrm{O})$ of the water column in the summer spring low tide during the low (a) and high (b) gas flow release; and in the neap ebb tide during the low (c) and high (d) gas flow release.

The gas plume displacement during the summer period was toward south-southwest and plume width reached up to $2.7 \mathrm{~m}$ close to the surface. During the winter period, the gas plume width was higher than $1.3 \mathrm{~m}$ close to the surface and the plume presented a northeast-northward displacement. These results confirmed that gas plume displacement was always influenced by the tidal and meteorological forcing. Examples of screenshots of the submarine recordings during summer and winter are presented in Figure 6. They correspond to the vertical evolution of a 9000 $\mathrm{L} / \mathrm{hr}$ natural gas plume released during the summer period for neap/ebb and spring/flood tides. 

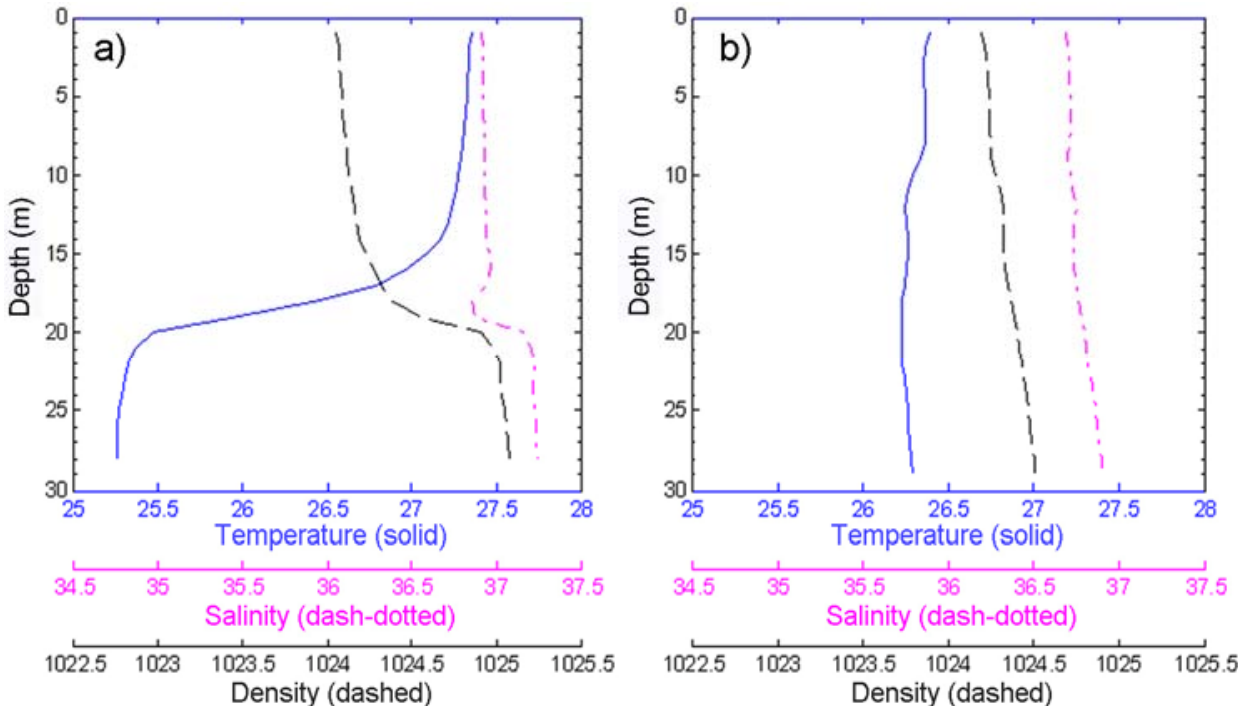

Figure 5. Examples of vertical CTD profiles obtained off Suape Harbor, Brazil, during: (a) austral summer; and (b) austral winter period. 


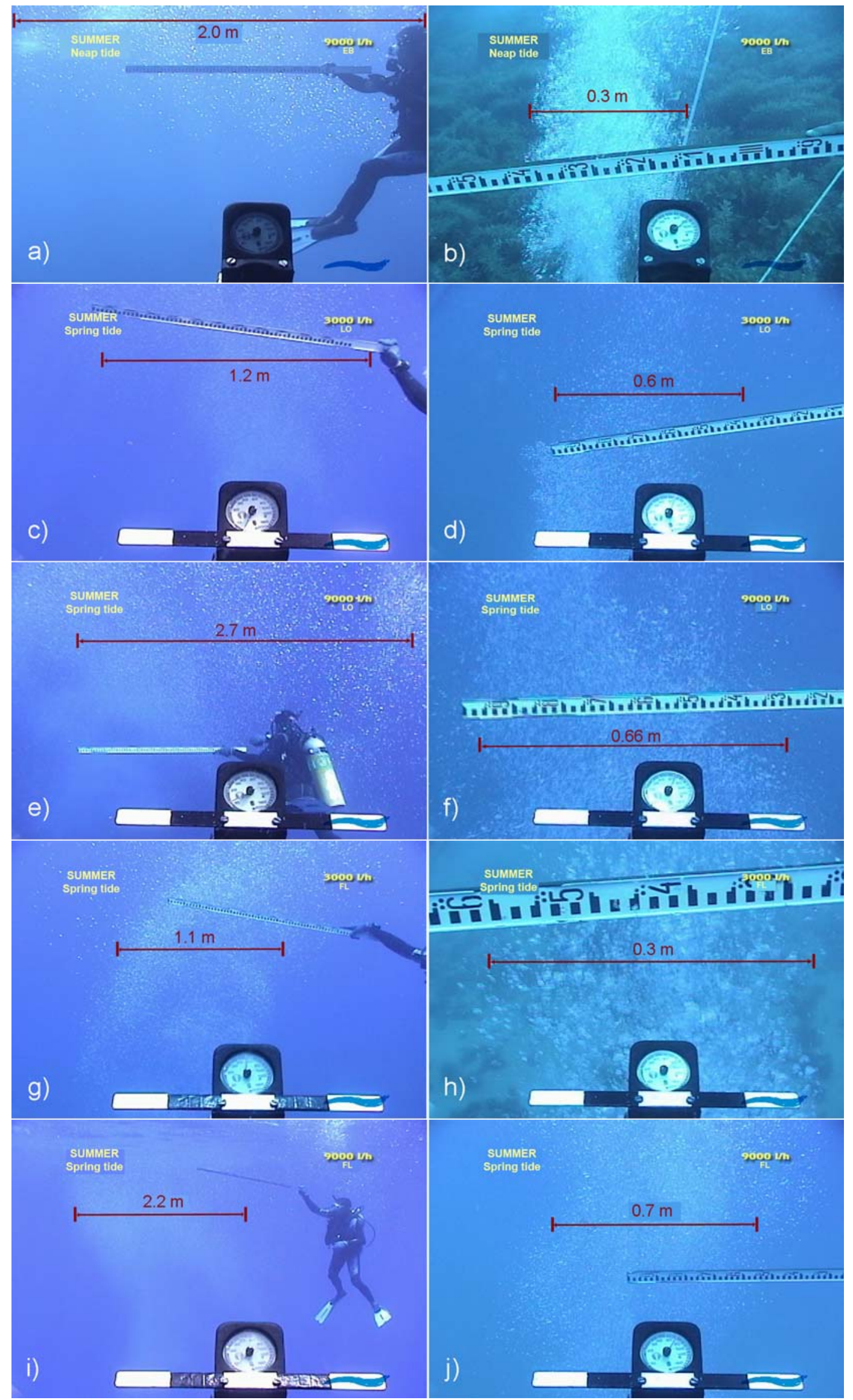


Figure 6. Screenshots of the natural gas plume vertical evolution during the summer period campaigns. Neap ebb tide at the depths of (a) $4 \mathrm{~m}$ and (b) $24 \mathrm{~m}$ during high flow release. Spring low tide at the depths of (c) $1.5 \mathrm{~m}$ and (d) $19 \mathrm{~m}$ during low flow release and of (e) $4 \mathrm{~m}$ and (f) $20 \mathrm{~m}$ during high flow release. Spring flood tide at the depths of (g) $15 \mathrm{~m}$ and (h) $24 \mathrm{~m}$ during low flow release and of (i) $3 \mathrm{~m}$ and (j) $21 \mathrm{~m}$ during high flow release.

\section{Comparison Between In Situ Observations and the Model's Results}

The experimental data obtained by the field campaigns at the study area and synthesized in the Methods and Materials section were used to threedimensionally model the transport of the natural gas plume generated from the GASOCEAN model's routines. This procedure allowed for the estimation of the radius of action of the gas plume along the entire depth (bottom $\rightarrow$ surface) as a function of the physical-oceanographic conditions.

The GASOCEAN model was forced from horizontal advective fields and in situ thermodynamic profiles. Examples of plume evolutions throughout the water column are presented in Figures 7-9 for different types of forcing during the summer and winter periods. In each figure, the gas plume trajectories are plotted along the south-north axis (S-N, positive toward north) and west-east (W-E, positive toward east). The horizontal lines in Figures 7-9 correspond to the observed plume diameter at that specific depth.

The vertical plume evolution reproduced under the environmental conditions of $\mathrm{C} 1$ campaign for an ebb tide pointed mainly southwestward (Figure 7). The simulation of a bottom release of $6000 \mathrm{~L} / \mathrm{hr}$ of vehicular natural gas (VNG) presented a plume radius on the order of $0.6 \mathrm{~m}$ (Figures $7 \mathrm{a}-7 \mathrm{~b}$ ). The radius oscillated between the hose diameter (the gas source at the sea bottom) and $0.6 \mathrm{~m}$, reaching this value in the first meters of ascending. A horizontal distance of $26.5 \mathrm{~m}$ from the gas source was achieved by the plume at the sea surface. Figures 7c-7d show a $9000 \mathrm{~L} / \mathrm{hr}$ gas blowout, which was reproduced for $\mathrm{C} 1$ campaign. In this situation, the plume radius was approximately $1.2 \mathrm{~m}$ and stabilized a few centimeters above the gas source. The plume centerline reached a distance of $28.3 \mathrm{~m}$ from the release source when it arrived at the sea surface. The ascending 
time (bottom $\rightarrow$ surface) of the gas plume was almost 1.6 minutes, which implies a vertical velocity of $0.3 \mathrm{~m} / \mathrm{s}$. The horizontal plume displacement became more pronounced above $15 \mathrm{~m}$, which was near the base depth of the clines.
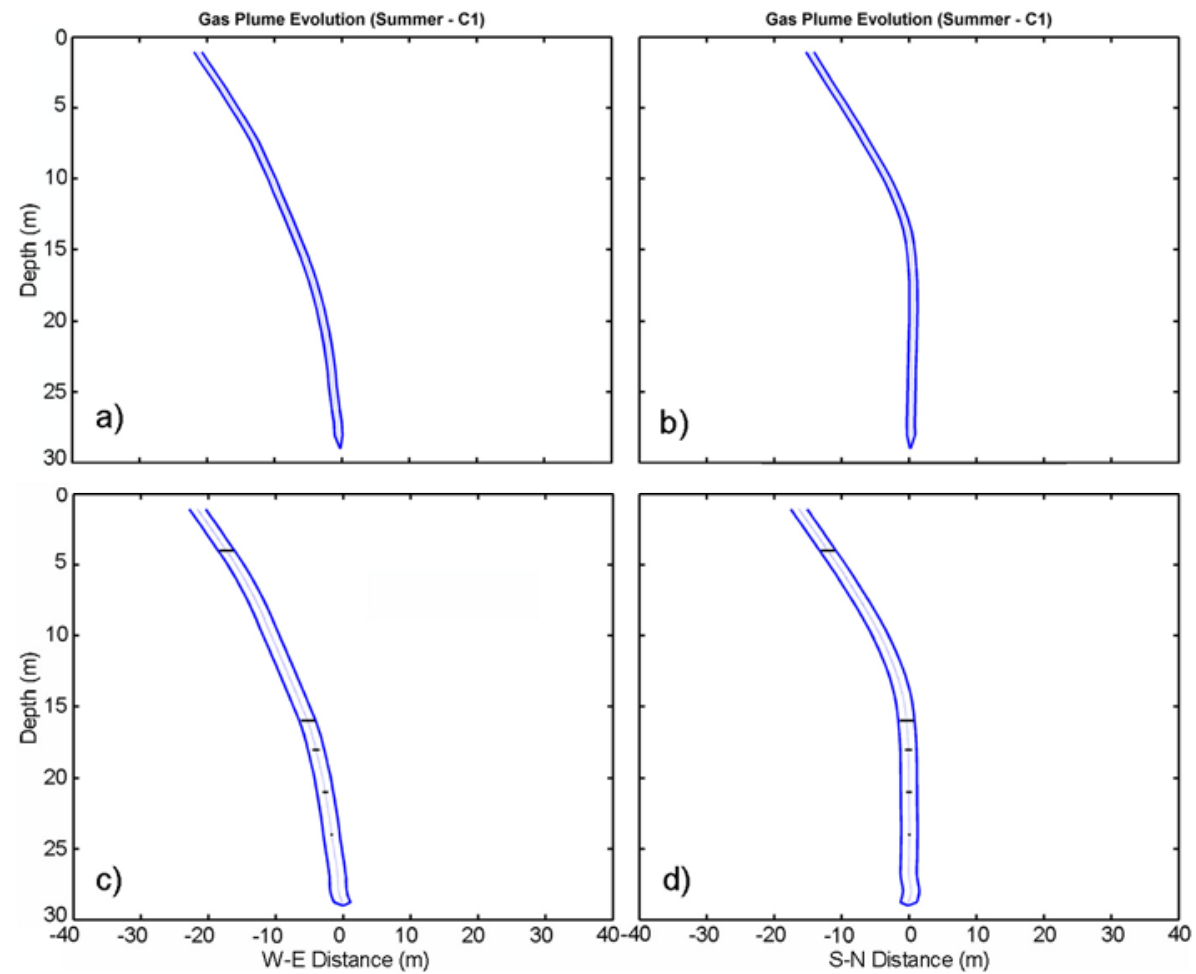

Figure 7. Gas plume evolution for $\mathrm{C} 1$ campaign (summer/ neap tide) during the ebb tide from (a) east to west and (b) north to south with a $6000 \mathrm{~L} / \mathrm{hr}$ flow and (c) east to west and (d) north to south with a $9000 \mathrm{~L} / \mathrm{hr}$ flow. The horizontal lines correspond to the observed plume diameter at the specific depth.

For the $\mathrm{C} 2$ campaign, the slack water period is shown in Figures 8a$8 \mathrm{~d}$. By the time of the lowest flow release $(3000 \mathrm{~L} / \mathrm{hr})$, the plume radius was near $0.6 \mathrm{~m}$ and had reached this value a few centimeters above the gas source. The horizontal displacement of the plume occurred above 18 $\mathrm{m}$, moving mainly toward southwest, $23 \mathrm{~m}$ from the source of gas. When the gas release of $9000 \mathrm{~L} / \mathrm{hr}$ was simulated, the plume radius duplicated, reaching $1.2 \mathrm{~m}$ right above the gas source. The distance from the release source achieved by the plume radius was $25.2 \mathrm{~m}$ in the surface, moving westward. With an ascending velocity of the plume of $0.3 \mathrm{~m} / \mathrm{s}$, it took approximately 1.55 minutes to reach the surface. 

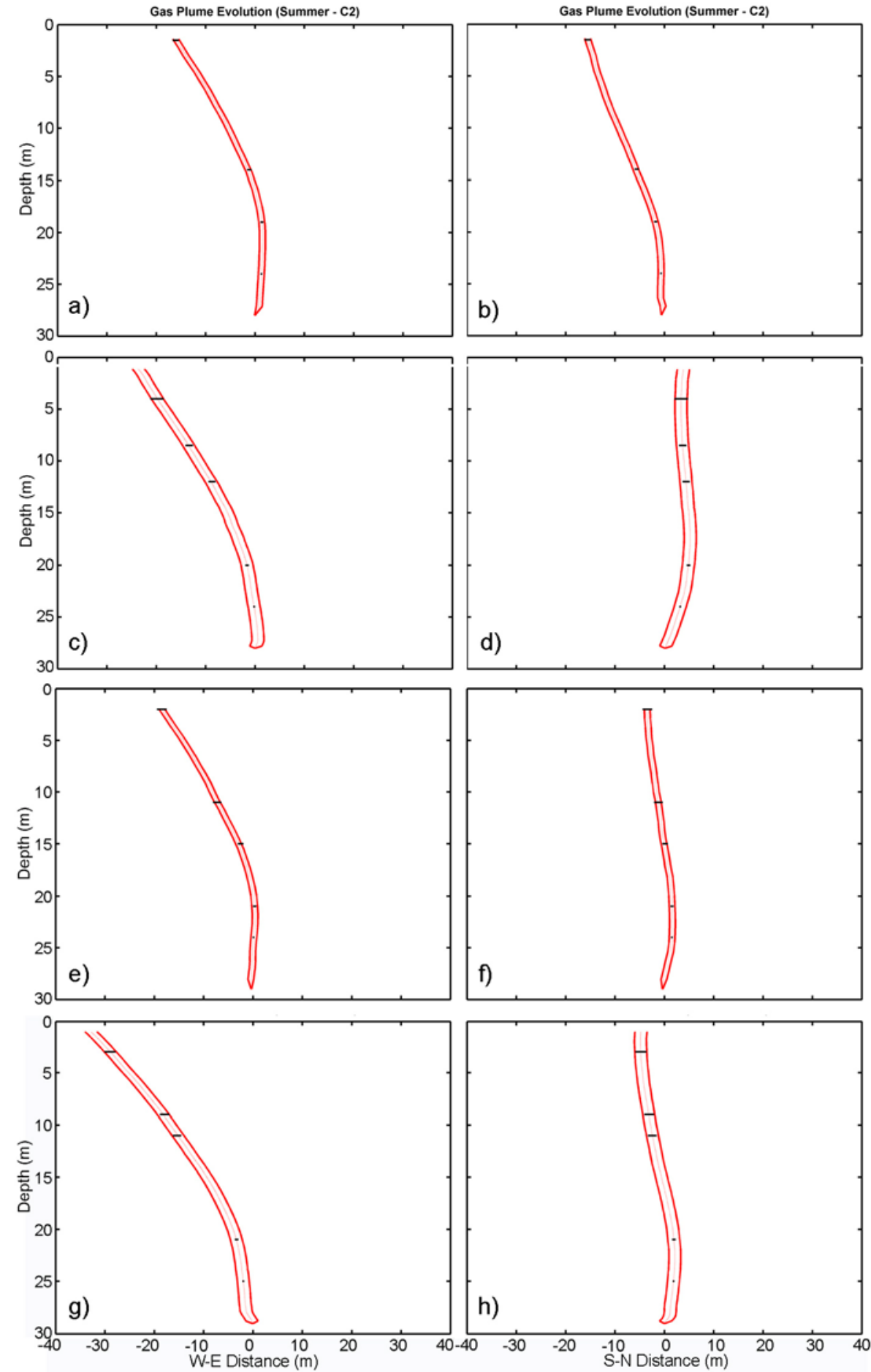

Figure 8. Gas plume evolution for $\mathrm{C} 2$ campaign (summer/ spring tide) during the low tide from (a) east to west and (b) north to south with a $3000 \mathrm{~L} / \mathrm{hr}$ flow and (c) east to west and (d) north to south with a $9000 \mathrm{~L} / \mathrm{hr}$ flow. During the flood tide, (e) east to west and (f) north to south with a $3000 \mathrm{~L} / \mathrm{hr}$ flow and (g) east to west and (h) north to south with a $9000 \mathrm{~L} / \mathrm{hr}$ flow. The horizontal lines correspond to the observed plume diameter at the specific depth. 
The dynamic flood period observed during the C2 campaign is presented in Figures 8e-8h. For both flow releases, the plume parameters were similar to those from the slack water period of the same release, although moving westward. The difference observed was in the plume displacement. The simulation of a $3000 \mathrm{~L} / \mathrm{hr}$ bottom gas release presented a more evident displacement above 18 meters, with a distance from the source of $19.4 \mathrm{~m}$. For the highest flow release, the horizontal plume displacement was more pronounced above $20 \mathrm{~m}$, where the plume centerline reached a distance from the release source of $34.4 \mathrm{~m}$.

The simulated plumes presented in Figures 9a-9h represent the $\mathrm{C} 4$ campaign. During high tide (Figures 9a-9d), the plume radius was on the order of $0.6 \mathrm{~m}$ when considering the gas release of $3000 \mathrm{~L} / \mathrm{hr}$. In the high release, the radius was twofold, specifically $1.2 \mathrm{~m}$. The plume's centerline emerged in the sea surface 11.6 (12.3) $\mathrm{m}$ far from the gas source during the 3000 (9000) L/hr release toward the northeast.

In the dynamic ebb tide period (Figures 9e-9h), the radius of the plume presented the same values of the slack water period for both flow releases. The plumes also displaced toward the northeast, taking 1.6 minutes to reach the surface with an upward velocity of $0.3 \mathrm{~m} / \mathrm{s}$; however, in this scenario, the bend was more pronounced and reached longer distances. For the low release, the plume centerline reached the surface at a distance of $32.2 \mathrm{~m}$ from the release source, while, during the higher release, it achieved $35.2 \mathrm{~m}$. 

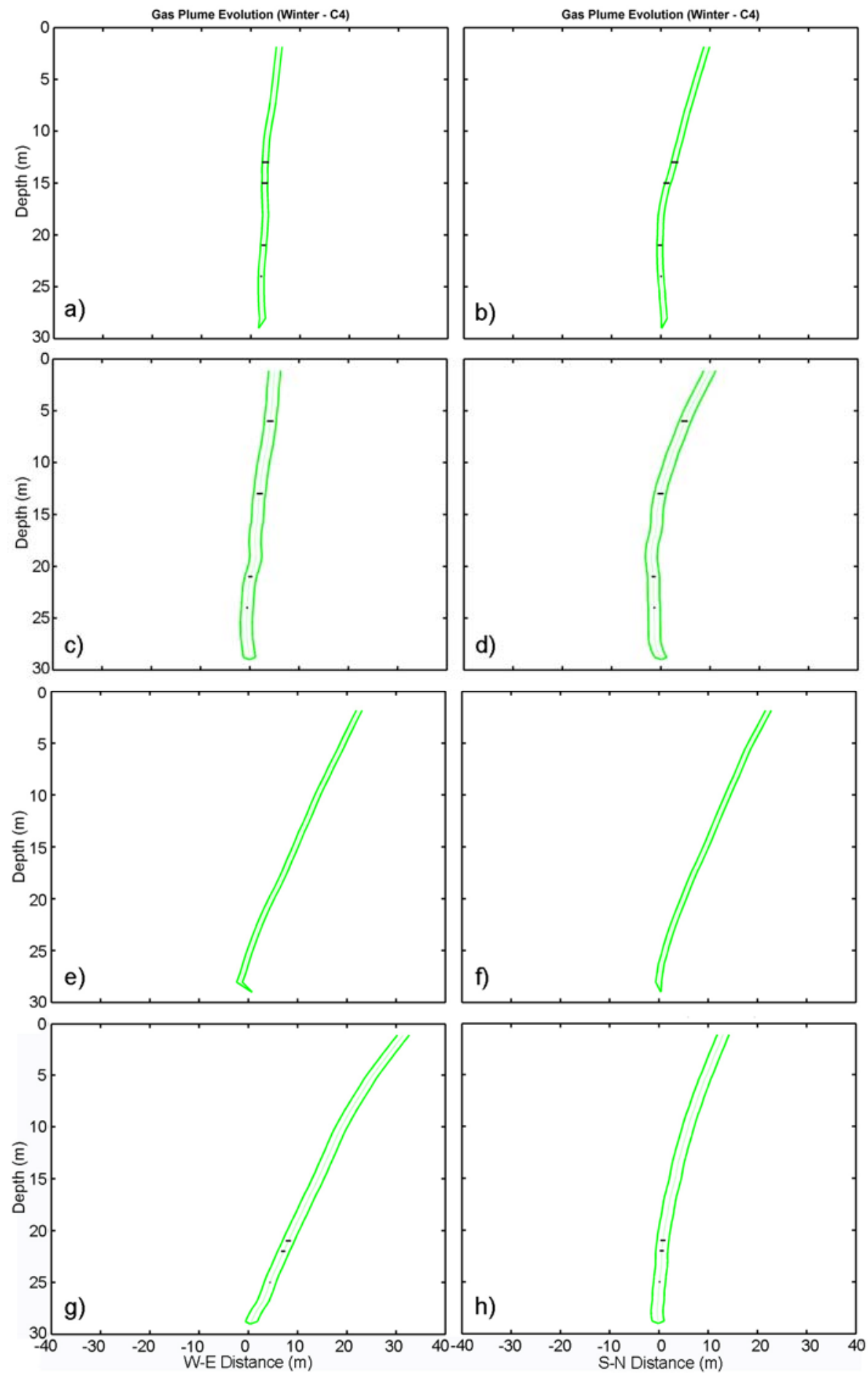

Figure 9. Gas plume evolution for $\mathrm{C} 4$ campaign (winter/ neap tide) during the high tide from (a) east to west and (b) north to south with a $3000 \mathrm{~L} / \mathrm{hr}$ flow; and (c) east to west and (d) north to south with a $9000 \mathrm{~L} / \mathrm{hr}$ flow. During the ebb tide, (e) east to west and (f) north to south with a $3000 \mathrm{~L} / \mathrm{hr}$ flow and (g) east to west and (h) north to south with a $9000 \mathrm{~L} / \mathrm{hr}$ flow. The horizontal lines correspond to the observed plume diameter at the specific depth. 
Once the evolution of the gas plume was simulated, it was possible to obtain the value of maximum horizontal displacement from the gas source achieved by the gas plume, which is called the critical radius. Presented in Figure 10 is the critical radius for each of the four campaigns. The plume displacement occurred inside a radius of $35 \mathrm{~m}$ from the gas release source. This greatest distance of the gas plume outbreak at the sea surface was observed during the winter neap ebb tide toward the northeast. During this period of the $\mathrm{C} 4$ campaign, the highest mean intensities were registered, reaching $0.5 \mathrm{~m} / \mathrm{s}$ at the surface when the high flow was released.
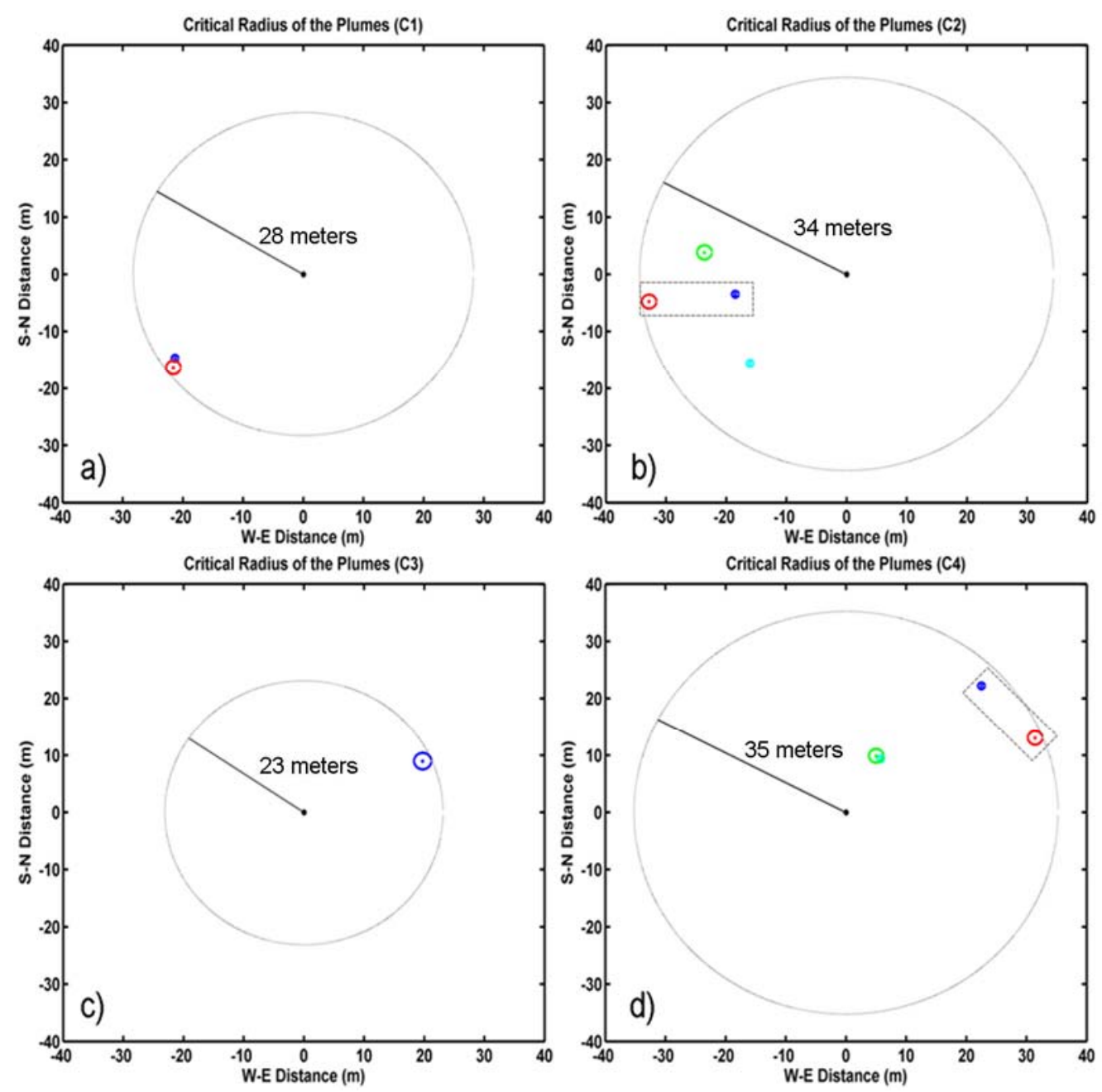

Figure 10. Gas plume distances from the gas source at the moment that they reach the sea surface: (a) summer neap ebb tide (small/large circles for low/high flows); (b) summer spring tide (small/large circles for low/high flows during flood tide, inside a dashed rectangle, and small/large dashed circles for low/high flows 
during low tide); (c) winter spring low tide (high flow); (d) winter neap tide (small/large circles for low/high flows during ebb tide, inside a dashed rectangle, and small/large dashed circles for low/high flows during high tide).

The first campaign indicated a critical radius of $28 \mathrm{~m}$ when the plume emerged to the sea surface. The results of the $\mathrm{C} 2$ campaign presented a critical radius of up to $34 \mathrm{~m}$, which occurred during the highest flow release in the spring flood tide. The shortest critical radius of $23 \mathrm{~m}$ was registered during the C3 campaign under the conditions of a low tide scenario. In this circumstance, the plume horizontal transport followed the advective fields, inducing the plume to displace northeastward with a plume radius of $1.4 \mathrm{~m}$ and a distance from the source of $23 \mathrm{~m}$ at surface. The ascending time was similar to that during the dry period and was approximately 1.1 minutes.

\section{DISCUSSION}

Comparing the experimental and numerical results, the model responds positively in reproducing the plume evolution throughout the water column. Observations from the submarine recordings showed bubbles rising up to the sea surface, which is in accordance with the model's results.

Simulations indicated gas plume displacement in the southwestnortheast axis with a southwest direction for the summer campaigns (C1 and C2). This transport was expected once the dominant current occurred toward as a consequence of the observed northeasterly trade winds during this period. Additionally, the registered current intensities appeared stronger during the spring flood tide of the $\mathrm{C} 2$ campaign, reaching 0.7 $\mathrm{m} / \mathrm{s}$ at the surface during the $9000 \mathrm{~L} / \mathrm{hr}$ flow release. For the winter period campaigns (C3 and $\mathrm{C} 4)$, the gas plumes were completely displaced northeastward from the release source, thus in agreement to the measured in situ horizontal current fields.

The plume widths calculated by the GASOCEAN model, for all scenarios, have the same order of magnitude as those registered by 
submarine records. However, the simulated plume widths stabilized a few centimeters above the gas source and presented a nearly constant value for each flow release in all sea campaigns $(0.6 \mathrm{~m}$ for low flow and 1.2 for high flow rates). These values are often represented by the highest diameter recorded on the video. In contrast, the vertical plume evolution from all the campaigns presented an increasing width along the water column. However, this parameter maintained the same order of magnitude between the measurements and the calculations. Further sensibility tests involving new parameterizations of the entrainment coefficient will be necessary to reproduce the along depth evolution of the plume width with higher precision correcting these differences. Some discrepancies about this parameter have been observed by other authors (i.e., Rye et al. 1997; Yapa and Xie 2002). Those authors also observed that the values of the plume diameter were different compared to the simulations and measurements results. The simulated plume width was generally smaller than the measured plume width. They suggested that discrepancies were associated to the interference of the remotely operated vehicle (ROV), combined to the use of low entrainment coefficient values.

The upwelling times of the gas plumes were similar, which were approximately 1.5 minutes, and were associated with the surrounding temperature conditions and the relative density between the fluids (the gas and water). Concerning the critical radius, the greatest value was observed during the $\mathrm{C} 4$ campaign during the winter neap ebb tide. Stronger influence for this plume displacement was the wind forcing, as the upper layers' momentum are directly sustained by surface wind stress (Wunsch 2002). Additionally, the weak influence of the tidal forcing helps to make the wind action more pronounced, as observed by Araujo et al. (2005) in the coastal area of Suape Harbor. As in the C4 campaign, the weak influence of the neap tide ( $\mathrm{C} 1$ campaign) led to prevailing action from the winds.

A thermocline (vertical temperature differences greater than $2^{\circ} \mathrm{C}$ ) was observed between the $20 \mathrm{~m}$ and $24 \mathrm{~m}$ depths, and was caused by the daily 
variation of solar radiation. The bend of the plume was observed at this depth, probably due to stronger current intensities over the plume along these depths. The plume curvature observed during the $\mathrm{C} 4$ campaign in the dynamic ebb tide period was strictly related to the current velocity, once it was more intense during this higher gas release, registering up to $0.5 \mathrm{~m} / \mathrm{s}$ in the surface layers.

The plume of the C3 campaign was closer to the gas source. However, focusing on the slack water period, this critical radius was above the average. The observed differences between the C2 and C3 campaigns were the tidal stages and the vertical stratification depths. The vertical temperature gradients were observed in shallow depths (from the surface to $6 \mathrm{~m}$ depth). Near these depths, stronger currents caused the plume to bend. During the C4 campaign, the bottom of the plume in the W-E direction for the low flow presented a displacement eastward due to plume, which was mirrored in the $\mathrm{x}-\mathrm{z}$ plan.

\section{CONCLUSION}

A synthesis of the comparison between the model's results and sea measurement for the main characteristics of the gas plume campaigns is presented in Table 3. The comparison between the measured and the calculated data indicate that the GASOCEAN model satisfactorily represents the main features of the gas release, such as the displacement, diameter, and ascending time of the plume. However, the calculation of the vertical evolution of earlier gas plume width must be improved to more precisely reproduce the real situation. Moreover, other blowout combinations (flow rates, durations, etc.) and natural forcings (different periods of the year) will result in distinct configurations of the plume displacement and should therefore be double-checked by using the same methods adopted in this study. Nevertheless, the presented results and discussed herein represent an original and very useful dataset for calibration and validation of underwater gas blowout models in tropical and shallow oceanic systems. 
Table 3. Synthesis observed (in situ) and modeled results gas plume features for different sea campaigns.

\begin{tabular}{cccccccccc}
\hline \multirow{2}{*}{ Period } & $\begin{array}{c}\text { Campaign- } \\
\text { Tide }\end{array}$ & \multicolumn{2}{c}{$\begin{array}{c}\text { Mean upwelling } \\
\text { time (min) }\end{array}$} & \multicolumn{2}{c}{$\begin{array}{c}\text { Plume } \\
\text { transport }\end{array}$} & \multicolumn{2}{c}{$\begin{array}{c}\text { Mean width } \\
(\mathrm{m})\end{array}$} & \multicolumn{2}{c}{$\begin{array}{c}\text { Critical } \\
\text { radius }(\mathrm{m})\end{array}$} \\
\cline { 2 - 11 } & In situ & Model & $\begin{array}{c}\text { In } \\
\text { situ }\end{array}$ & Model & $\begin{array}{c}\text { In } \\
\text { situ }\end{array}$ & Model & $\begin{array}{c}\text { In } \\
\text { situ }\end{array}$ & Model \\
\hline \multirow{2}{*}{ Summer } & C1- Neap & 1.5 & 1.55 & S & SW & 2.0 & 1.8 & 26 & 28.3 \\
\cline { 2 - 11 } & C2 - Spring & 1.45 & 1.45 & SW & W-SW & 2.7 & 2.1 & 31 & 34.4 \\
\hline \multirow{2}{*}{ Winter } & C3 - Spring & 1.4 & 1.10 & NE & NE & 2.0 & 2.8 & 20 & 23 \\
\cline { 2 - 11 } & C4 - Neap & 1.5 & 1.48 & $\begin{array}{c}\text { NE- } \\
\text { N }\end{array}$ & NE & 1.4 & 1.8 & 32 & 35.2 \\
\hline
\end{tabular}

\section{ACKNOWLEDGEMENTS}

This research was supported by the Brazilian National Research Council (CNPq) under the project grants 550197/2005-2 (CTPetro 16/2005) and 558143/2009-1 (CTHidro/CTInfra 38/2009). The authors are also thankful to everyone who was engaged in the sea campaigns.

\section{REFERENCES}

Aragao JOR. 2004. A influência dos Oceanos Pacífico e Atlântico na dinâmica do tempo e do clima do Nordeste do Brasil. In: Eskinazi-Leça E, Neumann-Leitao S, and Costa MF (eds), Oceanografia: Um cenário tropical, 1st edit, pp 131-84. Edições Bagaço, Recife, PE, Brazil

Araujo M, Lheritier D, Silva MA, et al. 2005. Tidal turbulence and eddyviscosity in coastal waters at northeastern Brazil. J Coastal Res 21:1827

Araujo M, Limongi C, Servain J, et al. 2011. Salinity-induced mixed and barrier layers in the Southwestern tropical Atlantic Ocean off the Northeast of Brazil. Ocean Sci 7:63-73

Betti R and Barrucho LG. 2010. Como poupar meio milhão e arruinar uma empresa. A economia de 500000 dólares com um dispositivo de segurança levará a BP a gastar 37 bilhões de dólares em multas, reparos e indenizações. Editora ABRIL, Veja 2174(43) 
Brewer PG, Orr Jr FM, Friederich G, et al. 1997. Deep-ocean field test of methane hydrate formation from a remotely operated vehicle. Geol 25:407-10

Brewer PG, Orr Jr FM, Friederich G, et al. 1998. Gas hydrate formation in the deep sea: in situ experiments with controlled release of methane, natural gas, and carbon dioxide. Energy Fuels 12:183-8

Bulatov MG, Kravtsov YuA, Raev MD, et al. 2002. Microwave, optical and IR combined studies of the sea surface perturbations caused by underwater gas bubble plumes. IEEE Geosci Remote Sens Symp, IGARSS 2002, 5:2983-5

Chen FH and Yapa PD. 2001. Estimating hydrate formation and decomposition of gases released in a deepwater ocean plume. J Mar Syst 30:21-32

Chen FH and Yapa PD. 2002. A model for simulating deepwater oil and gas blowouts - Part II: comparison of numerical simulations with "DeepSpill" field experiments. J Hydraul Res 41:353-65

Chen FH and Yapa PD. 2004. Modeling gas separation from a bent deepwater oil and gas jet/plume. J Mar Syst 45:189-203

Dasanayaka LK and Yapa PD. 2009. Role of plume dynamics phase in a deepwater oil and gas release model. J Hydro-environ Res 2:243-53

Davidson MJ and Pun KL. 1999. Weakly advected jets in cross-flow. J Hydraul Eng 125:47-58

Davidson MJ and Wang HJ. 2002. Strongly advected jet in a coflow. J Hydraul Eng 128:742-52

EEA (European Environment Agency). 2003. Mapping the Impacts of Recent Natural Disasters and Technological Accidents in Europe. Environmental Issue Report 35. Copenhagen, Denmark

Englezos P, Kalogerakis N, Dholabhai PD, et al. 1987. Kinetics of formation of methane and ethane gas. Chem Eng Sci 42:2647-58

Fanneløp TK and Sjøen K. 1980. Hydrodynamics of underwater blowouts. Norw Marit Res 4:17-33 
Friedl MJ and Fanneløp TK. 2000. Bubble plumes and their interaction with the water surface. Appl Ocean Res 22:119-28

Johansen $\varnothing$. 2000. DeepBlow - a Lagrangian plume model for deep water blowouts. Spill Sci Technol Bull 6:103-11

Johansen Ø. 2003. Development and verification of deep-water blowout models. Mar Pollut Bull 47:360-8

Johansen $\varnothing$, Rye H, and Cooper C. 2003. DeepSpill - Field study of a simulated oil and gas blowout in deep water. Spill Sci Technol Bull $8: 433-43$

Johansen Ø, Rye H, Melbye AG, et al. 2001. DeepSpill JIP - Experimental Discharges of Gas and Oil at Helland Hansen, June 2000. Technical Report. SINTEF Report STF66 F01082. SINTEF Applied Chemistry, Trondheim, Norway

Koh $\mathrm{R}$ and Fan L. 1970. Mathematical Models for the Prediction of Temperature Distribution Resulting from the Discharge of Heated Water into Large Bodies of Water. EPA Report. Water Pollut Control Res Ser 16130DWO10/70. Water Quality Office, Washington DC, USA

Lee JHW and Chueng V. 1990. Generalized Lagragian model for buoyant jets in current. J Environ Eng 116:1085-106

Leifer I, Luyendyk BP, Boles J, et al. 2006. Natural marine seepage blowout: Contribution to atmospheric methane. Global Biogeochem Cycles 20:GB3008

Lins PAM. 2002. Hidrologia e hidrodinâmica do baixo estuário do Rio Ipojuca, PE. Department of Oceanography. MSc Thesis. Federal University of Pernambuco, Recife, Brazil

Peel MC, Finlayson BL, and Mcmahon TA. 2007. Updated world map of the Köppen-Geiger climate classification. Hydrol Earth Syst Sci $11: 1633-44$

Rye H, Brandvik PJ, and Strom T. 1997. Subsurface blowouts: Results from field experiments. Spill Sci Technol Bull 4:239-56

Silva MA. 2004. Modelagem matemática do transporte e dispersão de uma pluma de hidrocarbonetos na região costeira de Suape - PE, Brasil. 
Department of Oceanography. MSc Thesis. Federal University of Pernambuco, Recife, Brazil

Socolofsky SA and Adams EE. 2002. Multi-phase plumes in uniform and stratified crossflow. J Hydraul Res 40:661-72

Spaulding ML, Bishnoi PR, Anderson E, et al. 2000. An integrated model for prediction of oil transport from a deep water blowout. 23rd AMOP Technical Seminar. Vancouver, BC, Canada

Topham DR. 1984a. The formation of gas hydrates on bubbles of hydrocarbon gases rising in seawater. Chem Eng Sci 39:821-8

Topham DR. 1984b. The modeling of hydrocarbon bubble plumes to include gas hydrate formation. Chem Eng Sci 39:1613-122

Wunsch C. 2002. What is the thermohaline circulation? Science 298: $1179-80$

Yapa PD and Xie H. 2002. Modeling underwater oil/gas jets and plumes: comparison with field data. J Hydraul Eng 128:855-60

Yapa PD and Zheng L. 1997. Simulation of oil spills from underwater accidents I: model development. J Hydraul Res 35:673-87

Yapa PD, Zheng L, and Nakata K. 1999. Modeling underwater oil/gas jets and plumes. J Hydraul Eng 125:481-91

Yapa PD, Zheng L, and Chen FH. 2001. A model for deepwater oil/gas blowouts. Mar Pollut Bull 43:234-41

Yapa PD, Dasanayaka LK, Bandara UC, et al. 2008a. Modeling the impact of an accidental release of methane gas in deepwater. OCEANS 2008, Quebec, Canada. doi: 10.1109/OCEANS.2008.5151817

Yapa PD, Nakata K, Dasanayaka LK, et al. 2008b. A model for gas and hydrates plumes in deep ocean. OCEANS 2008 - MTS/IEEE Kobe Techno-Ocean'08, Kobe, Japan. doi: 10.1109/OCEANSKOBE.2008.4530912

Zheng L and Yapa PD. 1998. Simulation of oil spills from underwater accidents. II: model verification. J Hydraul Res 36:117-34

Zheng L and Yapa PD. 2000. Buoyant velocity of spherical and nonspherical bubbles/droplets. J Hydraul Eng 126:852-4 
Zheng L and Yapa PD. 2002. Modeling gas dissolution in deepwater oil/gas spills. J Mar Syst 31:299-309.

Zheng L, Yapa PD, and Chen FH. 2002. A model for simulating deepwater oil and gas blowouts - Part I: theory and model formulation. J Hydraul Res 41:339-51

\section{APPENDIX A. GASOCEAN MODEL}

The GASOCEAN model uses a Lagrangian control volume approach for discretization. The plume evolution is calculated through the vertical displacement of this Lagrangian control volume along the ocean depth for each numerical time step. This displacement occurs due to the non-linear features between the current velocity fields and the initial momentum of the plume. The position of the control volume along the simulation is obtained by the following equations:

$$
\mathrm{h}=|\mathrm{V}| \cdot \Delta \mathrm{t}
$$

and

$$
\Delta \mathrm{t}=0.1 \cdot \mathrm{b}_{0} /\left|\mathrm{V}_{0}\right|,
$$

where $\mathrm{h}=$ the depth of the control volume $[\mathrm{m}],|\mathrm{V}|=$ the local plume velocity $\left[\mathrm{m} \cdot \mathrm{s}^{-1}\right]$, and $\Delta \mathrm{t}=\mathrm{a}$ specified time step [s]. In Eq. (2), $\mathrm{b}_{0}=$ the ratio of the initial control volume $[\mathrm{m}]$ in contact with the sea bottom, which is obtained from the blowout release, and $\left|\mathrm{V}_{0}\right|=$ the initial blowout velocity $\left[\mathrm{m} \cdot \mathrm{s}^{-1}\right]$.

The main equations used in GASOCEAN model describing the gas plume evolution are presented as follows and further detailed explanations may be found in Yapa and Zheng (1997), Zheng et al. (2002), and Chen and Yapa (2004). The notation of variables used in the model is presented in Appendix B. 
The momentum equations are applied to the average conditions in each control volume, taking into account the relative velocities between the gas and liquid:

$$
\begin{aligned}
& \frac{d}{d t}\left[\left(m_{l}+m_{b}+m_{h}\right) u\right]=u_{a} \rho_{a} Q_{e}-u \rho_{c o m} Q_{g} \\
& \frac{d}{d t}\left[\left(m_{l}+m_{b}+m_{h}\right) v\right]=v_{a} \rho_{a} Q_{e}-v \rho_{c o m} Q_{g}
\end{aligned}
$$

The momentum equation in the vertical direction, with the incorporation of bubble ascending velocities relative to the slip (buoyant) velocity, is given by the following equation:

$$
\begin{aligned}
& \frac{\mathrm{d}}{\mathrm{dt}}\left[\mathrm{m}_{\mathrm{l}} \mathrm{w}+\left(\mathrm{m}_{\mathrm{b}}+\mathrm{m}_{\mathrm{h}}\right)\left(\mathrm{w}+\mathrm{w}_{\mathrm{b}}\right)\right]= \\
& \quad \mathrm{w}_{\mathrm{a}} \rho_{\mathrm{a}} \mathrm{Q}_{\mathrm{e}}-\mathrm{w} \rho_{\text {com }} \mathrm{Q}_{\mathrm{g}}+\left(\rho_{\mathrm{a}}-\rho_{\mathrm{l}}\right) \mathrm{g} \pi \mathrm{b}^{2}(1-\beta \varepsilon) \mathrm{h}+\left(\rho_{\mathrm{a}}-\rho_{\text {com }}\right) \mathrm{g} \pi \mathrm{b}^{2} \beta \varepsilon \mathrm{h}
\end{aligned}
$$

where $\mathrm{m}_{\mathrm{l}}=$ the plume liquid mass $[\mathrm{kg}], \mathrm{m}_{\mathrm{b}}=$ the plume gas mass $[\mathrm{kg}], \mathrm{m}_{\mathrm{h}}=$ the mass of hydrates inside the plume $[\mathrm{kg}], \mathrm{u}=$ the horizontal plume velocity in the $\mathrm{x}$ direction $\left[\mathrm{m} \cdot \mathrm{s}^{-1}\right], \mathrm{u}_{\mathrm{a}}=$ the ambient horizontal velocity in the $\mathrm{x}$ direction $\left[\mathrm{m} \cdot \mathrm{s}^{-1}\right], \rho_{\mathrm{a}}=$ the density of the ambient seawater $\left[\mathrm{kg} \cdot \mathrm{m}^{-3}\right]$, which was obtained from the field data, $Q_{e}=$ the entrainment water flux $\left[\mathrm{m}^{3} \cdot \mathrm{s}^{-1}\right], \rho_{\text {com }}=$ the composite density of the hydrates and gas $\left[\mathrm{kg} \cdot \mathrm{m}^{-3}\right], \mathrm{Q}_{\mathrm{g}}=$ the gas flux $\left[\mathrm{m}^{3} \cdot \mathrm{s}^{-1}\right], \mathrm{v}=$ the horizontal plume velocity in the $\mathrm{y}$ direction $\left[\mathrm{m} . \mathrm{s}^{-1}\right]$ and $\mathrm{v}_{\mathrm{a}}=$ the ambient horizontal velocity in the $\mathrm{y}$ direction $\left[\mathrm{m} . \mathrm{s}^{-1}\right]$, which was obtained from field data. For the vertical direction, $w=$ the plume vertical velocity $\left[\mathrm{m} . \mathrm{s}^{-1}\right], \mathrm{w}_{\mathrm{a}}=$ the ambient vertical velocity $\left[\mathrm{m} . \mathrm{s}^{-1}\right]$, $\mathrm{w}_{\mathrm{b}}=$ the gas bubble (or bubble slip) velocity $\left[\mathrm{m} . \mathrm{s}^{-1}\right], \rho_{1}=$ the liquid density of the plume $\left[\mathrm{kg} \cdot \mathrm{m}^{-3}\right], \mathrm{g}=$ the acceleration due to gravity $\left[\mathrm{m}^{2} \cdot \mathrm{s}^{-1}\right], \mathrm{b}=$ the plume radius $[\mathrm{m}], \beta=$ the ratio between the cross-sectional areas occupied by the gas and that of the plume and $h=$ the control volume height $[\mathrm{m}]$, which ranges from 0.65 to 0.8 for vertical plumes (Yapa and Zheng 1997). 
The gas bubble volume fraction inside the control volume, including hydrate shells, is represented by $\varepsilon=\left(\rho_{1}-\rho\right) /\left(\rho_{1}-\rho_{\text {com }}\right)$, where $\rho=$ the density of gas plume and liquid mixture $\left[\mathrm{kg} \cdot \mathrm{m}^{-3}\right]$.

Lee and Cheung (1990) proposed that the entrainment is the combination of shear-induced entrainment and forced entrainment. The former occurs because of shear between the plume and the ambient fluid and is always present even with no ambient currents. The latter is considered when the advection of ambient fluid into the plume takes place. The equations resulted from the work of above authors are given below:

$$
\mathrm{Q}_{\mathrm{s}}=2 \pi \mathrm{bh} \alpha|\overrightarrow{\mathrm{V}}|-\mathrm{V}_{\mathrm{a}}^{\prime} \mid
$$

in which $\mathrm{Q}_{\mathrm{s}}=$ shear-induced entrainment, and $\alpha=$ entrainment coefficient.

$$
\begin{aligned}
& \mathrm{Q}_{\mathrm{x}}=\rho_{a}\left|u_{a}\right|\left(\pi b \Delta b|\cos \phi \cos \theta|+2 b \Delta s \sqrt{1-\cos \theta^{2} \cos \phi^{2}}+\frac{\pi b^{2}}{2}|\Delta(\cos \phi \cos \theta)|\right) \Delta \mathrm{t} \\
& \mathrm{Q}_{\mathrm{y}}=\rho_{a}\left|v_{a}\right|\left(\pi b \Delta b|\cos \phi \sin \theta|+2 b \Delta s \sqrt{1-\sin \theta^{2} \cos \phi^{2}}+\frac{\pi b^{2}}{2}|\Delta(\cos \phi \sin \theta)|\right) \Delta \mathrm{t} \\
& \mathrm{Q}_{\mathrm{z}}=\rho_{a}\left|w_{a}\right|\left(\pi b \Delta b|\sin \phi|+2 b \Delta s|\cos \phi|+\frac{\pi b^{2}}{2}|\Delta \sin \phi|\right) \Delta \mathrm{t}
\end{aligned}
$$

where $\mathrm{Q}_{\mathrm{x}}, \mathrm{Q}_{\mathrm{y}}$ and $\mathrm{Q}_{\mathrm{z}}=$ forced entrainment components in $\mathrm{x}, \mathrm{y}$ and $z$, respectively, $\mathrm{u}_{\mathrm{a}}, \mathrm{v}_{\mathrm{a}}$ and $\mathrm{w}_{\mathrm{a}}=$ components of $\overrightarrow{\mathrm{V}}_{\mathrm{a}}, \theta=$ angle between the $\mathrm{x}$ axis and the plume projection on the horizontal plane, $\Delta \mathrm{x}, \Delta \mathrm{y}$ and $\Delta \mathrm{z}=$ displacements of a control volume during one time step, which are found in $\Delta \mathrm{s}=\sqrt{\Delta \mathrm{x}^{2}+\Delta \mathrm{y}^{2}+\Delta \mathrm{z}^{2}}$.

The gas dissolution process in the liquid environment is considered through the following expression (Zheng and Yapa 2002): 


$$
\frac{d n}{d t}=K A\left(C_{s}-C_{0}\right)
$$

in which $\mathrm{n}=$ the number of moles of gas in a bubble [mol]. $\mathrm{K}=$ the mass transfer coefficient $\left[\mathrm{m} \cdot \mathrm{s}^{-1}\right], \mathrm{A}=$ the surface area of a gas bubble $\left[\mathrm{m}^{2}\right], \mathrm{C}_{\mathrm{s}}=$ the gas solubility (i.e., saturated value of $\mathrm{C}_{0}$ ) $\left[\mathrm{mol} \cdot \mathrm{m}^{-3}\right]$ and $\mathrm{C}_{0}=$ the dissolved gas concentration [mol. $\left.\mathrm{m}^{-3}\right]$.

The theoretical concept developed by Davidson and Pun (1999) and Davidson and Wang (2002) is applied for estimating the eventual separation between gas and oil plumes throughout the seawater column. This approach defines the excess momentum (per unit density - $\mathrm{M}_{0}$ ) of the mixture according to the environment forcing for each time step as follows:

$$
\mathrm{M}_{0}=\pi\left(\mathrm{U}_{0}-\mathrm{U}_{\mathrm{A}}\right) \mathrm{U}_{0} \mathrm{~b}_{0}^{2}
$$

where $\mathrm{M}_{0}=$ excess momentum in the control volume (gas and oil) $\left[\mathrm{m}^{4} \cdot \mathrm{s}^{-4}\right]$, $\mathrm{U}_{0}=$ initial velocity of the gas and oil mixture $\left[\mathrm{m} . \mathrm{s}^{-1}\right]$, and $\mathrm{U}_{\mathrm{A}}=$ velocity of the currents in the ocean $\left[\mathrm{m} . \mathrm{s}^{-1}\right]$.

The characteristic length scale - $\mathrm{X}_{\mathrm{Sw}}[\mathrm{m}]$, which is calculated at each numerical time step, supplies an estimate of the transition point between the weakly advected and the strongly advected behavior. This order of magnitude estimate associates the excess momentum in the mixture (oil and gas) to the ocean momentum (always by units of density) and is represented by:

$$
X_{S W} \cong \frac{M_{0}^{1 / 2}}{U_{A}}
$$

Experimental data reveal that plumes separation $\left(\mathrm{X}_{\mathrm{SEP}}\right)$ actually occurs when the excess momentum in the ambient fluid is about hundredfold the momentum of the plumes, which means: 


$$
\frac{X_{\text {SEP }}}{\left(M_{0}^{1 / 2} / U_{A}\right)} \leq 100
$$

The variation (loss) of gaseous mass from the hydration and dissolution processes in the ambient water is given by the following equation:

$$
\frac{d m_{b}}{d t}=-f \cdot J \cdot \tau \cdot\left(\frac{d n}{d t}+\frac{d n_{s}}{d t}\right) M_{g},
$$

in which $\mathrm{dm}_{\mathrm{b}} / \mathrm{dt}=$ the gaseous mass loss due to hydration and dissolution $\left[\mathrm{kg} \cdot \mathrm{s}^{-1}\right], \mathrm{f}=\varepsilon$ is the gas fraction inside the control volume, $\mathrm{J}=$ the gas bubble flow inside the control volume [bubble $\mathrm{n}^{\mathrm{o}} \cdot \mathrm{s}^{-1}$ ], $\tau=\Delta \mathrm{t}$ is the gas traveling time through the control volume $[\mathrm{s}] \mathrm{dn} / \mathrm{dt}=$ the hydrate formation rate $\left[\mathrm{mol}_{\mathrm{s}} \mathrm{s}^{-1}\right]$ and $\mathrm{dn}_{\mathrm{s}} / \mathrm{dt}=$ the gas dissolution tax regarding the gas bubble [mol.s $\left.{ }^{-1}\right] . \quad \mathrm{M}_{\mathrm{g}}$ is the gas molecular weight $\left[\mathrm{kg} \cdot \mathrm{mol}^{-1}\right]$ according to the following equation:

$$
P M_{g}=\rho_{b} Z R T,
$$

where $\mathrm{P}=$ the ambient pressure $[\mathrm{Pa}], \mathrm{Z}=$ the compressibility factor, $\mathrm{R}=$ the universal gas constant $[8.31 \mathrm{~J} \cdot \mathrm{mol} . \mathrm{K}]$ and $\mathrm{T}=$ the temperature $[\mathrm{K}]$.

The liquid mass conservation for each time step is computed by the equation below:

$$
\frac{d m_{l}}{d t}=\rho_{a} Q_{e}-f \cdot n_{h} \frac{d n}{d t} M_{W},
$$

where $\mathrm{dm}_{1} / \mathrm{dt}=$ the gaseous mass loss due to dissolution $\left[\mathrm{kg} \cdot \mathrm{s}^{-1}\right], \mathrm{n}_{\mathrm{h}}=$ the hydrate number (ex.: $n_{h}=6$ for $\mathrm{CH}_{4}$ ) and $\mathrm{M}_{\mathrm{w}}=$ the water molecular weight [kg. $\left.\mathrm{mol}^{-1}\right]$. 


\section{APPENDIX B. PAPER'S NOTATIONS}

The following symbols are used in this paper:

\begin{tabular}{|c|c|}
\hline A & surface area of a gas bubble $\left[\mathrm{m}^{2}\right]$ \\
\hline $\mathrm{b}$ & plume radius $[\mathrm{m}]$ \\
\hline $\mathrm{b}_{0}$ & ratio of the initial control volume $[\mathrm{m}]$ \\
\hline $\mathrm{C}_{0}$ & dissolved gas concentration $\left[\mathrm{mol} . \mathrm{m}^{-3}\right]$ \\
\hline $\mathrm{C}_{\mathrm{s}}$ & dissolved gas saturation concentration (i.e., solubility) [mol.m-3] \\
\hline g & gravity acceleration $\left[\mathrm{m}^{2} \cdot \mathrm{s}^{-1}\right]$ \\
\hline $\mathrm{h}$ & depth of control volume or plume height $[\mathrm{m}]$ \\
\hline $\mathrm{k}$ & coefficient of mass transfer $\left[\mathrm{m} . \mathrm{s}^{-1}\right]$ \\
\hline $\begin{array}{c}\mathrm{m}_{\mathrm{b}}, \mathrm{m}_{\mathrm{h}}, \mathrm{m}_{1} \\
\mathrm{n}\end{array}$ & $\begin{array}{l}\text { mass of the gas, hydrates and liquid, respectively in the plume }[\mathrm{kg}] \\
\text { number of moles of gas in a bubble [mol] }\end{array}$ \\
\hline$Q_{e}$ & entrainment water flux $\left[\mathrm{m}^{3} \cdot \mathrm{s}^{-1}\right]$ \\
\hline$Q_{g}$ & gas flux $\left[\mathrm{m}^{3} \cdot \mathrm{s}^{-1}\right]$ \\
\hline$r_{b}$ & internal radius of the gas bubble $[\mathrm{m}]$ \\
\hline $\mathrm{r}_{\mathrm{h}}$ & external radius of the gas bubble (including hydrate) [m] \\
\hline $\mathrm{u}, \mathrm{v}$ & $\begin{array}{l}\text { plume horizontal velocities respectively in the } \mathrm{x} \text { and } \mathrm{y} \text { directions, } \\
\text { respectively }\left[\mathrm{m} . \mathrm{s}^{-1}\right]\end{array}$ \\
\hline$u_{a}$ & ambient horizontal velocities respectively in the $\mathrm{x}$ and $\mathrm{y}$ directions, \\
\hline$v_{a}$ & respectively $\left[\mathrm{m} . \mathrm{s}^{-1}\right]$ \\
\hline $\mathrm{W}$ & plume vertical velocity $\left[\mathrm{m} . \mathrm{s}^{-1}\right]$ \\
\hline $\mathrm{w}_{\mathrm{a}}$ & ambient vertical velocity $\left[\mathrm{m} \cdot \mathrm{s}^{-1}\right]$ \\
\hline $\mathrm{w}_{\mathrm{b}}$ & gas bubble (or bubble slip) velocity $\left[\mathrm{m} \cdot \mathrm{s}^{-1}\right]$ \\
\hline$\beta$ & $\begin{array}{l}\text { ratio between the cross-sectional areas occupied by the gas and that } \\
\text { of the plume OR the gas core width/jet diameter }\end{array}$ \\
\hline$\varepsilon$ & volume fraction of gas bubbles (including hydrate) \\
\hline$\rho$ & density of the gas plume and the liquid mixture $\left[\mathrm{kg} \cdot \mathrm{m}^{-3}\right]$ \\
\hline$\rho_{\mathrm{a}}$ & density of the ambient seawater $\left[\mathrm{kg} \cdot \mathrm{m}^{-3}\right]$ \\
\hline$\rho_{\mathrm{b}}$ & gas density $\left[\mathrm{kg} \cdot \mathrm{m}^{-3}\right]$ \\
\hline$\rho_{\text {com }}$ & composite density of the hydrates and gas [kg. $\left.\mathrm{m}^{-3}\right]$ \\
\hline$\rho_{\mathrm{h}}$ & density of the hydrate $\left[\mathrm{kg} \cdot \mathrm{m}^{-3}\right]$ \\
\hline$\rho_{1}$ & liquid density of plume $\left[\mathrm{kg} \cdot \mathrm{m}^{-3}\right]$ \\
\hline$\Delta \mathrm{t}$ & specified time step $[\mathrm{s}]$ \\
\hline
\end{tabular}


Leite F.S.

$|\mathrm{V}| \quad$ local plume velocity $\left[\mathrm{m} \cdot \mathrm{s}^{-1}\right]$

$\left|\mathrm{V}_{0}\right| \quad$ initial blowout velocity [m. $\left.\mathrm{s}^{-1}\right]$ 


\section{Chapter 5}

\section{Conclusions and Perspectives}

The increasing demand for offshore production and exploration of gas and oil has directed the attention to the sea in the last decades due to such lucrative activity. As the number of subsea installations for petroleum exploration increases, the risk of potential accidents also increases. It is important to know where, when and how much gas will reach the surface. The use of computer models in contingency planning and emergency response is often required in order to simulate the behavior of gas/oil plumes if accidently released in the sea through wells or ships. On the other hand, realistic experiments, which are essential to verify the model response, are expensive, potentially dangerous and demand complex logistical planning. In consequence, the publication of these field experiments is sparse in the literature and the existing ones were done in temperate climate deep zones.

According to the motivations above, the main objective of this study was to enhance the knowledge concerning blowouts in shallow tropical waters. In order to achieve this intent, the evolution of natural gas plumes was analyzed under the coastal hydrodynamics of a region in the Northeast of Brazil. Field experiments were done during two different gas release rates at approximately $30 \mathrm{~m}$ depth in neap/spring tides of the 
summer/dry and winter/rainy periods. Afterward, a computational model was developed and applied to simulate the transport and dispersion of a subsurface gas plume released from shallow waters. The model used the field data as forcing and also for verification of the numerical results.

The field experiments during the simulated subsurface releases yielded unique data for shallow tropical waters. No discrepancy was observed between the gas release data and the control data. The gas flow

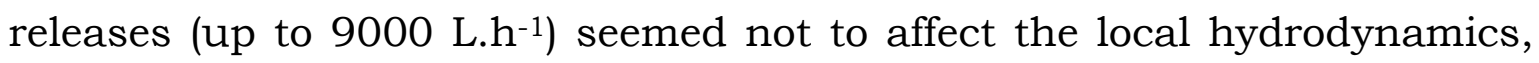
which followed its natural course where the meteorological and tidal forcing prevailed. The plume width was similar from the bottom to the middle depth of the water column for all of the campaigns. Differences appeared mainly in the upper surface layer, when the plume reached a width of up to $3 \mathrm{~m}$ close to the surface. The gas plume displacement was toward the south-southwest during the summer period and toward the northeast-north during the winter period being always influenced by the tidal and meteorological forcing.

The gas model was formulated from a set of routines produced in computational code using a Lagrangian control volume approach for discretization. The simulations of the gas plume evolution, associating thermodynamics and its impact on the hydrodynamics of the gas plume, were applied for several scenarios encountered during the field campaigns. It was possible to evaluate the temporal evolution of the gas plume transport during different seasons and gas flows.

Considering the difficulties faced in operating at sea and the singularity of the field data, the opportunity to compare these observed data with numerical results could not be missed. Simulations indicated gas plume displacement in the southwest-northeast axis with a southwest direction for the summer campaigns ( $\mathrm{C} 1$ and $\mathrm{C} 2)$. This transport was expected once the dominant current occurred toward this direction as a consequence of the observed northeasterly trade winds during this period. The registered current intensities appeared stronger during the spring flood tide of the $\mathrm{C} 2$ campaign, reaching $0.7 \mathrm{~m} . \mathrm{s}^{-1}$ at the surface during the 
9000 L.h ${ }^{-1}$ flow release. On the other hand, the gas plumes were completely displaced northeastward from the release source during the winter period campaigns ( $\mathrm{C} 3$ and $\mathrm{C} 4$ ), thus in agreement to the measured in situ horizontal current fields. The plume widths $(1.2-2.8 \mathrm{~m})$ and ascending times (1.1-1.6 min) from the modeling presented the same order of magnitude as those registered by submarine records for all scenarios.

The numerical results, as well as the experimental data, indicated that the gas plume is horizontally displaced toward the predominant current direction as the plume rises in the water column. The most extreme situation (maximum transport) was observed during the ebb tidal stage of the winter neap tide, which provided a critical radius (maximum horizontal displacement) of $35.2 \mathrm{~m}$ from the gas release source.

As this is the first known gas experiment performed in the shallow coastal waters of Brazil, it seems also important to register difficulties and suggestions for later studies. A considerable improvement for this methodology would be setting four GPS waypoints in a rectangular area, with the gas release location and the potential area for plume dispersion inside it to acquire better data for comparison. This simple practical approach would avoid additional efforts to align and to compare measurements issued from different campaigns. Another aspect is associated with the absence of a real-time strict recording control from the surface, which would lead to a better capture of the overall plume evolution.

The ADCP results sometimes did not registered the data, which could be associated with the intersection of the transmitted pulse with the gas bubbles. Several tests with the ADCP frequency should be taken into account. These experiments would help to calibrate the equipment and to obtain an accurate value to track gas bubbles. Besides, the water turbidity during winter campaigns lowered the quality of the video recordings. Such mishaps could be amended with the use of a camcorder spotlight or, even better, with the use of a remotely operated vehicle (ROV). 
Although the mean plume widths have the same order of magnitude between the measurements and the calculations, improvements may enhance the model's performance in reproducing precisely the real situation.

Nevertheless, the presented experimental results represent an original and very useful dataset for calibration and validation of underwater gas blowout models in tropical and shallow oceanic systems. The comparison between the measured and the calculated data indicate that the GASOCEAN model satisfactorily represents the main features of the gas release, such as the displacement, diameter, and ascending time of the plume. Other blowout combinations (flow rates, durations, etc.) and natural forcings (different periods of the year) will result in distinct configurations of the plume displacement and should therefore be doublechecked by using the same methods adopted in this study. 


\section{References}

Aragão, J.O.R., 2004. A influência dos Oceanos Pacífico e Atlântico na dinâmica do tempo e do clima do Nordeste do Brasil, in: EskinaziLeça, E., Neumann-Leitao, S., Costa, M.F. (Eds.), Oceanografia: Um cenário tropical. Edições Bagaço, Recife, PE, Brazil, pp. 131-184.

Araujo, M., Lheritier, D., Silva, M.A., Luna, M.C., Medeiros, C., 2005. Tidal turbulence and eddy-viscosity in coastal waters at northeastern Brazil. J. Coastal Res. 21, 18-27.

Araujo, M., Limongi, C., Servain, J., Silva, M., Leite, F.S., Veleda, D., Lentini, C.A.D., 2011. Salinity-induced mixed and barrier layers in the Southwestern tropical Atlantic Ocean off the Northeast of Brazil. Ocean Sci. 7, 63-73.

Araujo, M., Medeiros, C., Ribeiro, C., 1999. Energy balance and timescales of mixing and stratification in the Jaboatão estuary, NE-Brazil. Rev. Bras. Oceangr. 47, 145-154. 
Asaeda, T., Imberger, J., 1993. Structure of bubble plumes in linearly stratified environments. J. Fluid Mech. 249, 35-57.

Beegle-Krause, C.J., Lynch, W., 2005. Combining modeling with response in potential deep well blowout: lessons learned from thunder horse. Proc. Int. Oil Spill Conf., Miami Beach, pp. 1-6.

Betti, R., Barrucho, L.G., 2010. Como poupar meio milhão e arruinar uma empresa. A economia de 500000 dólares com um dispositivo de segurança levará a BP a gastar 37 bilhões de dólares em multas, reparos e indenizações. Editora ABRIL, Revista Veja 2174(43).

Bock, E.J., Hara, T., Frew, N.M., McGillis, W.R., 1999. Relationship between air-sea gas transfer and short wind waves. J. Geophys. Res. $104,25821-25831$.

Brewer, P.G., Orr Jr., F.M., Friederich, G., Kvenvolden, K.A., Orange, D.L., McFarlane, J., Kirkwood, W., 1997. Deep-ocean field test of methane hydrate formation from a remotely operated vehicle. Geol. 25, 407410.

Brewer, P.G., Orr Jr., F.M., Friederich, G., Kvenvolden, K.A., Orange, D.L., 1998. Gas hydrate formation in the deep sea: in situ experiments with controlled release of methane, natural gas, and carbon dioxide. Energy Fuels. 12(1), 183-188.

Bulatov, M.G., Kravtsov, Yu.A., Raev, M.D., Repina, I.A., Skvortsov, E.I., 2002. Microwave, optical and IR combined studies of the sea surface perturbations caused by underwater gas bubble plumes. IEEE Geosci. Remote Sens. Symp. IGARSS 2002. 5, 2983-2985. 
Chen, F.H., Yapa, P.D., 2001. Estimating hydrate formation and decomposition of gases released in a deepwater ocean plume. J. Mar. Syst. 30, 21-32.

Chen, F.H., Yapa, P.D., 2002. A model for simulating deepwater oil and gas blowouts - Part II: comparison of numerical simulations with "DeepSpill" field experiments. J. Hydraul. Res. 41(4), 353-365.

Chen, F.H., Yapa, P.D., 2004. Modeling gas separation from a bent deepwater oil and gas jet/plume. J. Mar. Syst. 45, 189-203.

Dasanayaka, L.K., Yapa, P.D., 2009. Role of plume dynamics phase in a deepwater oil and gas release model. J. Hydro-environ. Res. 2(4), 243-253.

Davidson, M.J., Pun, K.L., 1999. Weakly advected jets in cross-flow. J. Hydraul. Eng. ASCE. 125 (1), 47-58.

Davidson, M.J., Wang, H.J., 2002. Strongly advected jet in a coflow. J. of Hydraul. Eng. 128, 742-752.

DHN - Diretoria de Hidrografia e Navegação, 2007. Tábuas das marés. WWW Page, http://www.dhn.mar.mil.br (accessed 12.05.2007).

DHN - Diretoria de Hidrografia e Navegação, 2008. Tábuas das marés. WWW Page, http://www.dhn.mar.mil.br (accessed 06.30.2008).

Englezos, P., Kalogerakis, N., Dholabhai, P.D., Bishnoi, P.R., 1987. Kinetics of formation of methane and ethane gas. Chem. Eng. Sci. 42, 2647-2658.

Fanneløp, T.K., Sjøen, K., 1980. Hydrodynamics of underwater blowouts. Norwegian Marit. Res. 4, 17-33. 
FEMAR - Fundação de Estudos do Mar, 2010. Estações maregráficas brasileiras - Pernambuco. Tabela $n^{\circ}$ 119. WWW Page, http://www.femar.com.br (accessed 09.16.2010).

Fischer, D.W., 1982. Managing technological accidents: two blowouts in the North Sea. IIASA Proc. Ser. Pergamon Press, Oxford.

Friedl, M.J., Fanneløp, T.K., 2000. Bubble plumes and their interaction with the water surface. Appl. Ocean Res. 22, 119-128.

Google Earth 6.2., 2010. Porto de Suape - Ipojuca 08.3953ㅇ, $34.965^{\circ} \mathrm{W}$. . Disponivel em: http://www.google.com/earth/index.html [Acessado em 21 de fevereiro 2010].

Johansen, Ø., 2000. DeepBlow - a Lagrangian plume model for deep water blowouts. Spill Sci. Technol. Bull. 6, 103-111.

Johansen, Ø., Rye, H., Melbye, A., Jensen, H., Serigstad, B., Knutsen, T., 2001. Deep Spill JIP Experimental Discharges of Gas and Oil at Helland Hansen, Parts I, II, and III - Tech. Rep. SINTEF Applied Chemistry, Norway.

Johansen, Ø., 2003. Development and verification of deep-water blowout models. Mar. Pollut. Bull. 47, 360-368.

Johansen, Ø., Rye, H., Cooper, C., 2003. DeepSpill - Field study of a simulated oil and gas blowout in deep water. Spill Sci. Technol. Bull. $8,433-443$.

Johansen, Ø., Rye, H., Melbye, A.G., Jensen, H.V., Serigstad, B., Knutsen, T., 2001. DeepSpill JIP-experimental discharges of gas and oil at 
Helland Hansen, June 2000, Technical Report. SINTEF Report STF66 F01082, SINTEF Applied Chemistry, Trondheim, Norway, 159 pp.

Koh, R., Fan, L., 1970. Mathematical models for the prediction of temperature distribution resulting from the discharge of heated water into large bodies of water. EPA Report. Water Pollut. Control Ser. 16/30 DWD 10/70.

Lee, J.H.W., Cheung, V., 1990. Generalized Lagragian model for buoyant jets in current. J. Environ. Eng. 116, 1085-1106.

Leifer, I., Luyendyk, B.P., Boles, J., Clark, J.F., 2006. Natural marine seepage blowout: Contribution to atmospheric methane. Global Biogeochem. Cycles. 20, GB3008.

LeNeveu, D.M., 2011. Analysis of potential acid gas leakage from wellbores in Alberta, Canada. Int. J. Greenhouse Gas Control. In Press, Corrected Proof, Available online 20 February 2011, ISSN 1750-5836, DOI: $10.1016 /$ j.ijggc.2011.01.009.

Lins, P.A.M., 2002. Hidrologia e hidrodinâmica do baixo estuário do Rio Ipojuca, PE. Department of Oceanography. MSc Thesis. Federal University of Pernambuco, Brazil.

McDougall, T.J., 1978. Bubble plumes in stratified environments. J. Fluid Mech. 85, 655-672.

Obanijesu, E.O., Macaulay, S.R.A., 2009. West African Gas Pipeline (WAGP) project: associated problems and possible remedies, in: Yanful, E.K. (Ed.), Appropriate Technology for Environmental 
Protection in the Developing World. Springer Books, Netherlands, pp. $101-112$.

Peel, M.C., Finlayson, B.L., McMahon, T.A., 2007. Updated world map of the Köppen-Geiger climate classification. Hydrol. Earth Syst. Sci. 11, $1633-1644$.

Rivkin, P.E., 2007. Hazards and hazard mitigation techniques for natural gas and hydrogen fueling operations. Process Saf. Prog. 26, 27-34.

Rye, H., Brandvik, P.J., Strom, T., 1997. Subsurface blowouts: Results from field experiments. Spill Sci. Technol. Bull. 4, 239-256.

Silva, M.A., Araujo, M., Servain, J., Peven, P., Lentini, C.A.D., 2009. HighResolution Regional Ocean Dynamics Simulation in the Southwestern Tropical Atlantic. Ocean Model. 30, 256-269.

Spaulding, M.L., Bishnoi, P.R., Anderson, E., Isaji, T., 2000. An integrated model for prediction of oil transport from a deep water blowout. 23rd AMOP Technical Seminar 2000, June 14-16, 2000, Vancouver, B.C., Canada, 611-635.

Topham, D.R., 1984a. The formation of gas hydrates on bubbles of hydrocarbon gases rising in seawater. Chem. Eng. Sci. 39 (5), 821828.

Topham, D.R., 1984b. The modeling of hydrocarbon bubble plumes to include gas hydrate formation. Chem. Eng. Sci. 39 (11), 1613-1622.

Wanninkhof, R., Asher, W.E., Ho, D.T., Sweeney, C.S., McGillis, W.R., 2009. Advances in quantifying air-sea gas exchange and environmental forcing. Annu. Rev. Mar. Sci. 1, 213-244. 
Wunsch, C., 2002. What is the thermohaline circulation? Science. 298, 1179-1180.

Yapa, P.D., Dasanayaka, L.K., Bandara, U.C., Nakata, K., 2008a. Modeling the impact of an accidental release of methane gas in deepwater. OCEANS 2008. 1-10.

Yapa, P.D., Nakata, K., Dasanayaka, L.K., Bandara, U.C., Sukizaki, S., Suzuki, S., 2008b. A Model for Gas and Hydrates Plumes in Deep Ocean. OCEANS 2008. 1-8.

Yapa, P.D., Xie, H., 2002. Modeling underwater oil/gas jets and plumes: comparison with field data. J. Hydraul. Eng. 128 (9), 855-860.

Yapa, P.D., Zheng, L., 1997. Simulation of oil spills from underwater accidents I: model development. J. Hydraul. Res. IAHR. 35 (5), 673687.

Yapa, P.D., Zheng, L., Chen, F.H., 2001. A model for deepwater oil/gas blowouts. Mar. Pollut. Bull. 43 (7), 234-241.

Yapa, P.D., Zheng, L., Nakata, K., 1999. Modeling underwater oil/gas jets and plumes. J. Hydraul. Eng. 125(5), 481-491.

Zappa, C.J., McGillis, W.R., Raymond, P.A., Edson, J.B., Hintsa, E.J., Zemmelink, H.J., Dacey, J.W.H., Ho, D.T., 2007. Environmental turbulent mixing controls on air-water gas exchange in marine and aquatic systems. Geophys. Res. Lett. 34, L10601, doi:10.1029/2006GL028790. 
Zheng, L., Yapa, P.D., 1998. Simulation of oil spills from underwater accidents. II: model verification. J. Hydraul. Res. IAHR. 36 (1), 117134.

Zheng, L., Yapa, P.D., 2000. Buoyant velocity of spherical and nonspherical bubbles/droplets. J. Hydraul. Eng. 126 (11), 852-854.

Zheng, L., Yapa, P.D., 2002. Modeling gas dissolution in deepwater oil/gas spills. J. Mar. Syst. 31, 299-309.

Zheng, L., Yapa, P.D., Chen, F.H., 2002. A model for simulating deepwater oil and gas blowouts - Part I: theory and model formulation. J. Hydraul. Res. IAHR. 41(4), 339-351. 